\title{
Silanediol-Catalyzed Chromenone Functionalization
}

Andrea M. Hardman-Baldwin, Michael D. Visco, Joshua M. Wieting, Charlotte Stern, Shin-ichi Kondo, and Anita E. Mattson*

Department of Chemistry and Biochemistry, The Ohio State University, $88 \mathrm{~W} .18^{\text {th }}$ Ave., Columbus, OH 43210

\section{Supplemental Section Table of Contents}

General Methods

Catalyst Preparation 2

General Procedure for the Preparation of Silyl Ketene Acetals

General Procedure for the Preparation of Chromenones 9

General Procedure for Addition of Silyl Ketene Acetals to Chromenones 13

General Procedure for the Formation of the N-sulfinyl Imine 16

Determination of the Major Enantiomer 16

Determination of Association Constant 19

References 20

Select HPLC Traces 21

Selected NMR Spectra 33

\section{General Methods}

Diethyl ether, methylene chloride, tetrahydrofuran, and toluene were purified by passage through a bed of activated alumina. Ethyl acetate, acetone, and hexanes were purchased and used as received. Purification of reaction products was carried out by flash chromatography using Silicycle SiliaFlash P60 silica gel $(40-63 \mu \mathrm{m})$. Analytical thin layer chromatography was performed on Analtech silica gel HLF uniplates (250 microns, UV254). Visualization was accomplished with UV light and ceric ammonium molybdate or potassium permanganate stains 
followed by heating. Melting points (mp) were obtained on a Fisher Scientific Mel-Temp apparatus and are uncorrected. Infrared spectra (IR) were obtained on a Thermo Scientific Nicolet iS5 with iD7 diamond ATR attachement. Proton nuclear magnetic resonances $\left({ }^{\mathbf{1}} \mathbf{H}\right.$ NMR) were recorded in deuterated solvents on a Bruker Avance AVIII 400 (400 MHz) spectrometer unless otherwise noted. Chemical shifts are reported in parts per million (ppm, $\square$ ) using the solvent as internal standard $\left(\mathrm{CDCl}_{3}, \square 7.26\right) .{ }^{1} \mathrm{H}$ NMR splitting patterns are designated as singlet $(\mathrm{s})$, doublet (d), triplet (t), or quartet (q). Splitting patterns that could not be interpreted or easily visualized are designated as multiplet $(\mathrm{m})$ or broad (br). Coupling constants are reported in Hertz (Hz). Proton-decoupled carbon $\left({ }^{\mathbf{1 3}} \mathbf{C}\right.$ NMR) spectra were recorded on a Bruker Avance AVIII $400(100 \mathrm{MHz})$ or a Bruker Avance AVIII $600(150 \mathrm{MHz})$ spectrometer and are reported in ppm using the solvent as an internal standard $\left(\mathrm{CDCl}_{3}, \square 77.0\right)$. Electrospray mass spectra (ESI-MS) were obtained using a Bruker MicrOTOF Mass Spectrometer. HPLC analyses were obtained on a Perkin Elmer Series 200 HPLC with multiple wavelength detector. Fluorescence spectra were recorded on a Hitachi F-7000 fluorescence spectrometer. Unless otherwise noted, all other commercially available reagents and solvents were used without further purification.

\section{Catalyst Preparation}

\section{Synthesis of SI-2:}
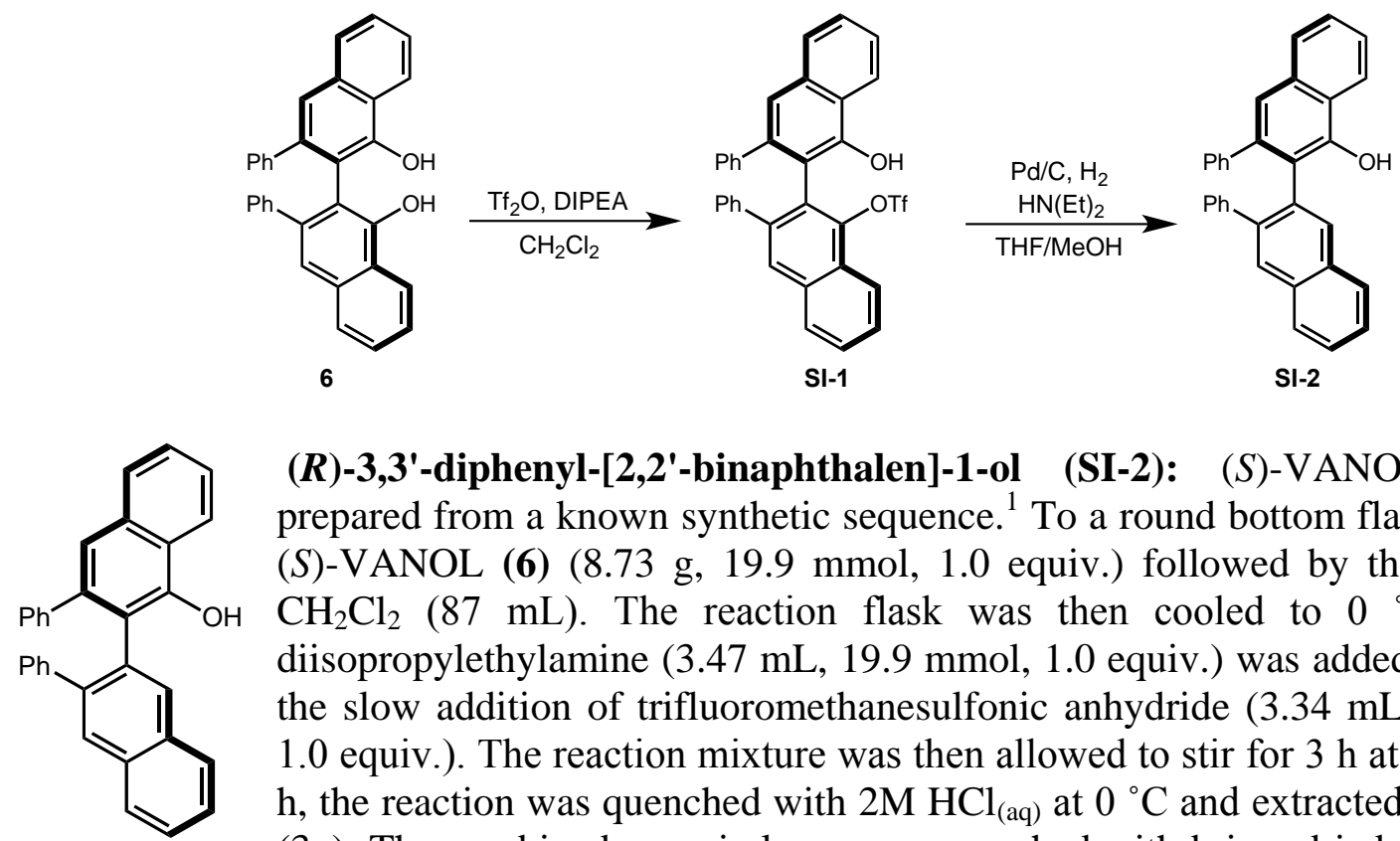

(R)-3,3'-diphenyl-[2,2'-binaphthalen]-1-ol (SI-2): (S)-VANOL (6) was prepared from a known synthetic sequence. ${ }^{1}$ To a round bottom flask was added $(S)$-VANOL (6) (8.73 g, $19.9 \mathrm{mmol}, 1.0$ equiv.) followed by the addition of $\mathrm{CH}_{2} \mathrm{Cl}_{2}(87 \mathrm{~mL})$. The reaction flask was then cooled to $0{ }^{\circ} \mathrm{C}$ and $\mathrm{N}, N$ diisopropylethylamine $(3.47 \mathrm{~mL}, 19.9 \mathrm{mmol}, 1.0$ equiv.) was added followed by the slow addition of trifluoromethanesulfonic anhydride $(3.34 \mathrm{~mL}, 19.9 \mathrm{mmol}$, 1.0 equiv.). The reaction mixture was then allowed to stir for $3 \mathrm{~h}$ at $0{ }^{\circ} \mathrm{C}$. After 3 $\mathrm{h}$, the reaction was quenched with $2 \mathrm{M} \mathrm{HCl}_{(\mathrm{aq})}$ at $0{ }^{\circ} \mathrm{C}$ and extracted with $\mathrm{CH}_{2} \mathrm{Cl}_{2}$ (3x). The combined organic layers were washed with brine, dried with $\mathrm{Na}_{2} \mathrm{SO}_{4}$, and concentrated in vacuo. The crude product was then run through a large silica plug using $\mathrm{CH}_{2} \mathrm{Cl}_{2}$ as the eluent. The resulting solid SI-1 (11.65 g) was used in the next step of the synthetic sequence without any further purification (see below for ${ }^{1} \mathrm{H}$ NMR spectrum).

To a flame dried round bottom flask was added slightly impure SI-1 (11.52 g, 20.18 mmol, 1.0 equiv.) and $10 \mathrm{wt} . \% \mathrm{Pd} / \mathrm{C}$ (3.22 g, $3.03 \mathrm{mmol}, 0.15$ equiv.). The flask was evacuated and purged with argon, followed by the addition of THF $(22 \mathrm{~mL})$, diethyl amine $(6.36 \mathrm{~mL}, 60.54$ mmol, 3.0 equiv.) and $\mathrm{MeOH}(75 \mathrm{~mL})$. The argon from the reaction flask was then evacuated and refilled with $\mathrm{H}_{2}$ (this cycle was repeated $3 \mathrm{x}$ ) and the reaction mixture was stirred under a balloon of $\mathrm{H}_{2}$ for $48 \mathrm{~h}$. After $48 \mathrm{~h}$, the reaction mixture was filtered through Celite using $\mathrm{CH}_{2} \mathrm{Cl}_{2}$ 
as the eluent and then the organic layer was washed with $2 \mathrm{M} \mathrm{HCl}_{(\mathrm{aq})}(3 \mathrm{x})$, dried with $\mathrm{Na}_{2} \mathrm{SO}_{4}$, and concentrated in vacuo. The resulting residue was purified via flash column chromatography on silica gel (80:20 hexanes: $\mathrm{CH}_{2} \mathrm{Cl}_{2}$ to $70: 30$ hexanes: $\mathrm{CH}_{2} \mathrm{Cl}_{2}$ ) to yield the title compound as a yellow solid (7.10 g, $16.8 \mathrm{mmol}, 84 \%$ over 2 steps). ${ }^{1} \mathrm{H}$ NMR (400 $\left.\mathrm{MHz}, \mathrm{CDCl}_{3}\right) \delta 8.34-8.37$ (m, $1 \mathrm{H}), 8.13(\mathrm{~s}, 1 \mathrm{H}), 7.93-7.95(\mathrm{~m}, 1 \mathrm{H}), 7.86-7.88(\mathrm{~m}, 1 \mathrm{H}), 7.76-7.79(\mathrm{~m}, 2 \mathrm{H}), 7.51-7.60(\mathrm{~m}, 4 \mathrm{H})$, $7.25(\mathrm{~s}, 1 \mathrm{H}), 7.03-7.12(\mathrm{~m}, 2 \mathrm{H}), 6.90-6.99(\mathrm{~m}, 4 \mathrm{H}), 6.59-6.65(\mathrm{~m}, 4 \mathrm{H}), 6.06(\mathrm{~s}, 1 \mathrm{H}) ;{ }^{13} \mathrm{C} \mathrm{NMR}$ $\left(100 \mathrm{MHz}, \mathrm{CDCl}_{3}\right) \delta 149.18,141.2,140.9,140.1,139.8,134.0,133.7,132.7,132.2,131.6$, $130.6,129.6,129.2,128.1,127.8,127.7,127.4,127.0,126.9,126.7,126.6,126.2,125.4,123.3$, $122.8,121.0,120.5$; mp 211-212 ${ }^{\circ} \mathrm{C}$; IR (neat) 3519, 3055, 2986, 2952, 2305, 2162, 1735, 1701 , 1625, 1274, 1132, 748, $701 \mathrm{~cm}^{-1}$; HRMS (ESI): Mass calculated for $\mathrm{C}_{32} \mathrm{H}_{22} \mathrm{ONa}^{+}[\mathrm{M}+\mathrm{Na}]^{+}$, 445.1563 Found $[\mathrm{M}+\mathrm{Na}]^{+}, 445.1558 ;[\alpha]^{23}{ }_{\mathrm{D}}=-220\left(\mathrm{c} 0.32, \mathrm{CHCl}_{3}\right)$.

\section{Synthesis of SI-3:}
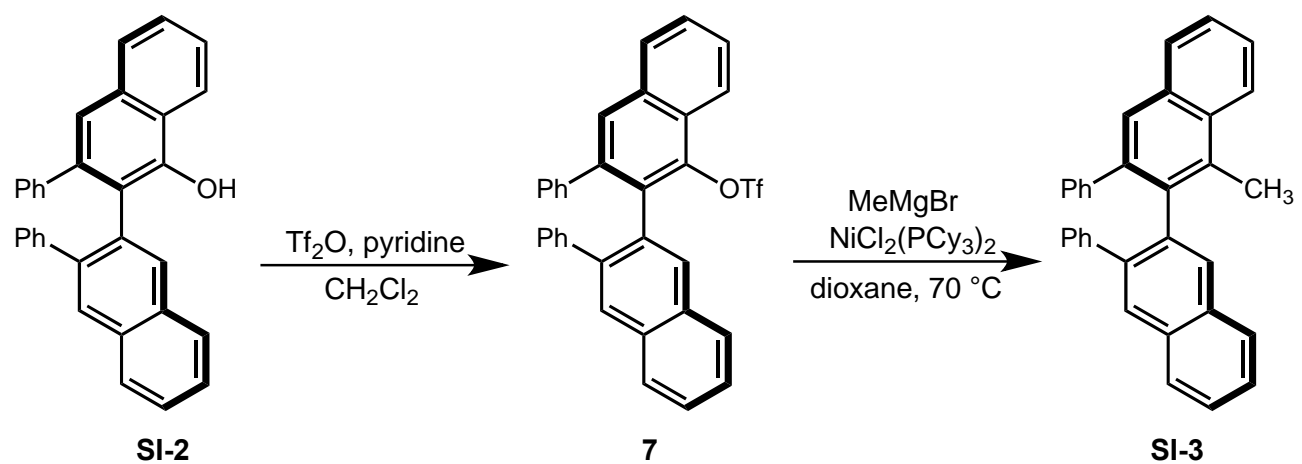

SI-3

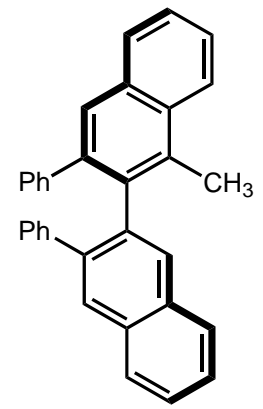

(S)-1-methyl-3,3'-diphenyl-2,2'-binaphthalene (SI-3): To a flame dried round bottom flask was added SI-2 (5.43 g, $12.85 \mathrm{mmol}, 1.0$ equiv.), $\mathrm{CH}_{2} \mathrm{Cl}_{2}(45 \mathrm{~mL})$ and pyridine $\left(5.19 \mathrm{~mL}, 64.25 \mathrm{mmol}, 5.0\right.$ equiv.). The flask was cooled to $0{ }^{\circ} \mathrm{C}$ and trifluoromethanesulfonic anhydride $(5.40 \mathrm{~mL}, 32.13 \mathrm{mmol}, 2.5$ equiv.) was added slowly. The reaction was the let warm to $23{ }^{\circ} \mathrm{C}$ and stir overnight. The reaction flask was then cooled to $0{ }^{\circ} \mathrm{C}$, quenched with $2 \mathrm{M} \mathrm{HCl}_{(\mathrm{aq})}$, and extracted with $\mathrm{CH}_{2} \mathrm{Cl}_{2}(3 \mathrm{x})$. The combined organic layers were washed $2 \mathrm{M} \mathrm{HCl}_{(\mathrm{aq})}$, brine, dried with $\mathrm{Na}_{2} \mathrm{SO}_{4}$, and concentrated in vacuo. The resulting residue was partially purified via flash column chromatography on silica gel (90:10 hexanes: $\mathrm{CH}_{2} \mathrm{Cl}_{2}$ to $85: 15$ hexanes: $\left.\mathrm{CH}_{2} \mathrm{Cl}_{2}\right)$. The resulting solid $7(6.96 \mathrm{~g})$ was used as is for the next synthetic step (see below for ${ }^{1} \mathrm{H}$ NMR spectrum).

To a flame dried two-neck round bottom flask was added slightly impure 7 (6.90 g) and $\mathrm{NiCl}_{2}\left(\mathrm{PCy}_{3}\right)_{2}(883 \mathrm{mg}, 1.28 \mathrm{mmol}, 0.1$ equiv.). The flask was then equipped with a condenser and the reaction system was purged with a continuous flow of $\mathrm{N}_{2}$. After the reaction system was under $\mathrm{N}_{2}$ atmosphere, freshly distilled and degassed 1,4-dioxane $(115 \mathrm{~mL})$ was added. The reaction flask was cooled to $0{ }^{\circ} \mathrm{C}$ and $\mathrm{MeMgBr}\left(2.63 \mathrm{M}\right.$ in $\mathrm{Et}_{2} \mathrm{O}, 14.7 \mathrm{~mL}, 38.5 \mathrm{mmol}, 3$ equiv.) was added slowly. The top of the condenser was then equipped with a vent needle and the reaction system was gradually heated to $70{ }^{\circ} \mathrm{C}$ allowing for the $\mathrm{Et}_{2} \mathrm{O}$ from the $\mathrm{MeMgBr}$ solution to evaporate out of the reaction system. The reaction was then stirred for $2 \mathrm{~h}$ at $70{ }^{\circ} \mathrm{C}$. After $2 \mathrm{~h}$, the reaction flask was cooled to $0{ }^{\circ} \mathrm{C}$ and $2 \mathrm{M} \mathrm{HCl}_{(\mathrm{aq})}$ was added slowly to quench the reaction. The reaction was then diluted with $\mathrm{H}_{2} \mathrm{O}$ and extracted with $\mathrm{Et}_{2} \mathrm{O}(3 \mathrm{x})$. The combined organic 
layers were washed with brine, dried with $\mathrm{Na}_{2} \mathrm{SO}_{4}$, and concentrated in vacuo. The resulting residue was then run through a large silica plug using $\mathrm{CH}_{2} \mathrm{Cl}_{2}$ as the eluent and concentrated in vacuo. The crude product was then purified via flash column chromatography on silica gel $(97: 3$ hexanes: $\mathrm{CH}_{2} \mathrm{Cl}_{2}$ to $95: 5$ hexanes: $\mathrm{CH}_{2} \mathrm{Cl}_{2}$ ) to afford the title compound as a while solid (4.91 g, $11.67 \mathrm{mmol}, 90 \%$ over 2 steps $).{ }^{1} \mathrm{H}$ NMR $\left(400 \mathrm{MHz}, \mathrm{CDCl}_{3}\right) \delta 8.12(\mathrm{~d}, J=8.4 \mathrm{~Hz}, 1 \mathrm{H}), 7.82-$ $7.85(\mathrm{~m}, 4 \mathrm{H}), 7.69(\mathrm{~s}, 1 \mathrm{H}), 7.49-7.59(\mathrm{~m}, 5 \mathrm{H}), 6.90-7.09(\mathrm{~m}, 6 \mathrm{H}), 6.64-6.72(\mathrm{~m}, 4 \mathrm{H}), 2.63(\mathrm{~s}$, $3 \mathrm{H}) ;{ }^{13} \mathrm{C}$ NMR $\left(100 \mathrm{MHz}, \mathrm{CDCl}_{3}\right) \delta 141.6,140.9,140.2,140.0,137.9,137.6,133.0,132.9$, $132.8,132.2$, 131.9, 130.0, 129.4, 129.0, 128.7, 127.9, 127.7, 127.5, 127.4, 127.2, 126.4, 126.2, 126.1, 126.0, 125.9, 124.7, 17.6; mp 96-100 ${ }^{\circ} \mathrm{C}$; IR (neat) 3054, 2987, 2950, 2154, 1735, 1701, 1625, 1591, 1494, 1274, 1265, 1131, $748 \mathrm{~cm}^{-1}$; HRMS (ESI): Mass calculated for $\mathrm{C}_{33} \mathrm{H}_{24} \mathrm{Na}^{+}$ $[\mathrm{M}+\mathrm{Na}]^{+}, 443.1770$ Found $[\mathrm{M}+\mathrm{Na}]^{+}, 443.1766 ;[\alpha]^{23}{ }_{\mathrm{D}}=-277\left(\mathrm{c} 0.16, \mathrm{CHCl}_{3}\right)$.

\section{Synthesis of 5c:}

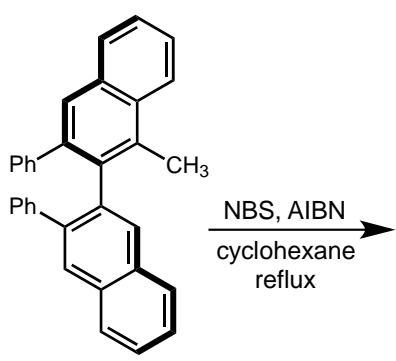

SI-3

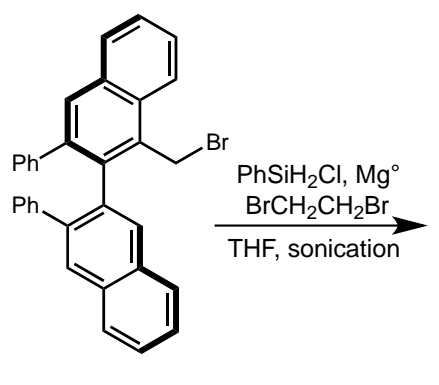

8

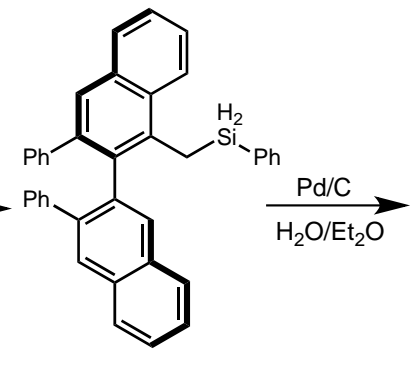

$\mathrm{SI}-4$

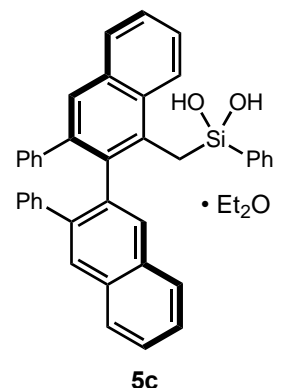

$5 c$<smiles>BrCc1c(-c2cc3ccccc3cc2-c2ccccc2)c(-c2ccccc2)cc2ccccc12</smiles>

(R)-1-(bromomethyl)-3,3'-diphenyl-2,2'-binaphthalene (8): To a flame dried round bottom flask was added SI-3 (4.80 g, $11.41 \mathrm{mmol}, 1.0$ equiv.), NBS (4.47 $\mathrm{g}, 25.10 \mathrm{mmol}, 2.2$ equiv.), AIBN (281 mg, $1.71 \mathrm{mmol}, 0.15$ equiv.) and cyclohexane $(225 \mathrm{~mL})$. The flask was then equipped with a water-cooled condenser and the reaction mixture was refluxed overnight. The reaction was then cooled to $23{ }^{\circ} \mathrm{C}$ and filtered through Celite with $\mathrm{Et}_{2} \mathrm{O}$. The resulting solution was then diluted with $\mathrm{H}_{2} \mathrm{O}$ and extracted with $\mathrm{Et}_{2} \mathrm{O}(3 \mathrm{x})$. The organic layers were combined and washed with saturated $\mathrm{NaHCO}_{3}$ (aq), brine, dried with $\mathrm{Na}_{2} \mathrm{SO}_{4}$, and concentrated in vacuo. The resulting residue was purified via flash column chromatography on silica gel (98:2 hexanes: $\left.\mathrm{Et}_{2} \mathrm{O}\right)$ to afford the title compound as a yellow solid $(5.57 \mathrm{~g}, 11.15$ mmol, 98\%). ${ }^{1} \mathrm{H}$ NMR (400 MHz, $\left.\mathrm{CDCl}_{3}\right) \delta 8.32(\mathrm{~d}, J=8.1 \mathrm{~Hz}, 1 \mathrm{H}), 8.26(\mathrm{~s}, 1 \mathrm{H}), 7.96-7.98(\mathrm{~m}$, $1 \mathrm{H})$, 7.84-7.87 (m, 2H), 7.69-7.71 (m, 1H), $7.67(\mathrm{~s}, 1 \mathrm{H}), 7.62(\mathrm{~s}, 1 \mathrm{H}), 7.52-7.58(\mathrm{~m}, 3 \mathrm{H}), 7.02-$ $7.09(\mathrm{~m}, 2 \mathrm{H}), 6.88-6.97(\mathrm{~m}, 4 \mathrm{H}), 6.60-6.62(\mathrm{~m}, 2 \mathrm{H}), 6.53-6.55(\mathrm{~m}, 2 \mathrm{H}), 5.25(\mathrm{~d}, J=10.2 \mathrm{~Hz}$, $1 \mathrm{H}), 4.88(\mathrm{~d}, J=9.9 \mathrm{~Hz}, 1 \mathrm{H}) ;{ }^{13} \mathrm{C} \mathrm{NMR}\left(100 \mathrm{MHz}, \mathrm{CDCl}_{3}\right) \delta 140.7,140.4,140.1,139.7,139.5$, $135.5,133.5,133.4,132.0,131.5,131.4,131.0,130.7,129.9,129.5,129.3,129.0,128.1,128.0$, 127.6, 127.3, 126.9, 126.6, 126.55, 126.53, 126.4, 126.3, 124.8, 31.1; mp 120-124 ${ }^{\circ} \mathrm{C}$; IR (neat) 3054, 2988, 2949, 2155, 1735, 1701, 1625, 1493, 1274, 1264, 1131, 749, $699 \mathrm{~cm}^{-1}$; HRMS (ESI): Mass calculated for $\mathrm{C}_{33} \mathrm{H}_{23} \mathrm{BrNa}^{+}[\mathrm{M}+\mathrm{Na}]^{+}, 521.0875$ Found $[\mathrm{M}+\mathrm{Na}]^{+}, 521.0881 ;[\alpha]^{23}{ }_{\mathrm{D}}=$ $-183\left(\mathrm{c} 0.52, \mathrm{CHCl}_{3}\right)$. 


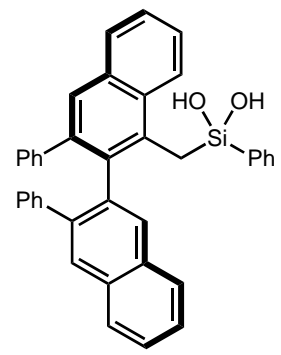

(R)-((3,3'-diphenyl-[2,2'-binaphthalen]-1-yl)methyl)(phenyl)silanediol (5c): To a flame dried round bottom flask was added magnesium powder (182 $\mathrm{mg}, 7.5 \mathrm{mmol}, 3.0$ equiv.), THF $(5 \mathrm{~mL})$. To a separate flame dried round bottom flask was added 8 (1.25 g, $2.5 \mathrm{mmol}, 1.0$ equiv.), THF (7.5 mL) and phenylchlorosilane (1.66 mL, $12.5 \mathrm{mmol}, 5.0$ equiv.). The reaction flask containing the magnesium power was placed in a sonicator water bath and subjected to sonication at $23{ }^{\circ} \mathrm{C}$. Immediately after beginning sonication, 1,2dibromoethane $(0.11 \mathrm{~mL}, 1.25 \mathrm{mmol}, 0.5$ equiv. $)$ was added to the reaction flask followed by the addition of the solution containing $\mathbf{8}$, phenylchlorosilane and THF. The reaction mixture was then sonicated for $1 \mathrm{~h}$ at $23{ }^{\circ} \mathrm{C}$. After $1 \mathrm{~h}$, the reaction was quenched with saturated $\mathrm{NH}_{4} \mathrm{Cl}_{(\mathrm{aq})}$, extracted with $\mathrm{Et}_{2} \mathrm{O}(3 \mathrm{x})$, dried over $\mathrm{Na}_{2} \mathrm{SO}_{4}$ and concentrated in vacuo. The resulting residue was subjected to flash column chromatography on silica gel (hexanes to 95:5 hexanes:Et ${ }_{2} \mathrm{O}$ ). The resulting slightly impure SI-4 (see ${ }^{1} \mathrm{H}$ NMR below) was used in the next synthetic sequence.

To a flame dried round bottom flask was added crude SI-4 and $10 \mathrm{wt}$ \% Pd/C (300 mg, $0.28 \mathrm{mmol}, 0.11$ equiv.). The reaction mixture was purged with argon followed by the addition of THF $(8 \mathrm{~mL})$ and $\mathrm{H}_{2} \mathrm{O}(0.8 \mathrm{~mL})$. The reaction was then stirred overnight. The mixture was then filtered through Celite, diluted with $\mathrm{H}_{2} \mathrm{O}$ and extracted with $\mathrm{Et}_{2} \mathrm{O}(3 \mathrm{x})$. The combined organic layers were washed with brine, dried with $\mathrm{Na}_{2} \mathrm{SO}_{4}$, and concentrated in vacuo. The resulting residue was purified via flash column chromatography on silica gel (hexanes to 60:40 hexanes:Et $\left.{ }_{2} \mathrm{O}\right)$ to afford the title compound as a white solid $(698 \mathrm{mg}, 1.25 \mathrm{mmol}, 50 \%$ over 2 steps). The silanediol exists as a 4:1 complex with $\mathrm{Et}_{2} \mathrm{O} .{ }^{1} \mathrm{H} \mathrm{NMR}\left(400 \mathrm{MHz}, \mathrm{CDCl}_{3}\right) \delta 8.14-$ $8.16(\mathrm{~m}, 1 \mathrm{H}), 7.78-7.84(\mathrm{~m}, 2 \mathrm{H}), 7.76(\mathrm{~s}, 1 \mathrm{H}), 7.69(\mathrm{~s}, 1 \mathrm{H}), 7.60-7.62(\mathrm{~m}, 1 \mathrm{H}), 7.41-7.54(\mathrm{~m}$, 7H), 7.32-7.37 (m, 1H), 7.19-7.23 (m, 2H), 6.91-7.09 (m, 6H), 6.77-6.80 (m, 2H), 6.71-6.74 (m, 2H), $2.98(\mathrm{~d}, J=14.6 \mathrm{~Hz}, 1 \mathrm{H}), 2.77(\mathrm{~d}, J=14.6 \mathrm{~Hz}, 1 \mathrm{H}), 2.53(\mathrm{~s}, 1 \mathrm{H}), 2.44(\mathrm{~s}, 1 \mathrm{H}) ;{ }^{13} \mathrm{C} \mathrm{NMR}$ $\left(100 \mathrm{MHz}, \mathrm{CDCl}_{3}\right) \delta 141.7,140.7,140.5,139.7,137.4,136.9,135.1,133.9,133.7,133.3,133.0$, $132.1,132.0,131.4,130.4,130.1,129.4,129.3,129.0,128.0,127.8,127.7,127.5,127.2,127.0$, $126.5,126.2,126.16,126.15,126.11,126.0,125.3,21.1$; IR (neat) 3517, 3054, 2949, 2163, 1735, 1701, 1493, 1274, 1264, 1131, 763, 748, $715 \mathrm{~cm}^{-1}$; mp 110-111 ${ }^{\circ} \mathrm{C}$; HRMS (ESI): Mass calculated for $\mathrm{C}_{39} \mathrm{H}_{30} \mathrm{O}_{2} \mathrm{SiNa}^{+}[\mathrm{M}+\mathrm{Na}]^{+}, 581.1907$ Found $[\mathrm{M}+\mathrm{Na}]^{+}, 581.1907 ;[\alpha]^{23}{ }_{\mathrm{D}}=-109(\mathrm{c}$ $\left.0.24, \mathrm{CHCl}_{3}\right)$. 


\section{Synthesis of 10:}

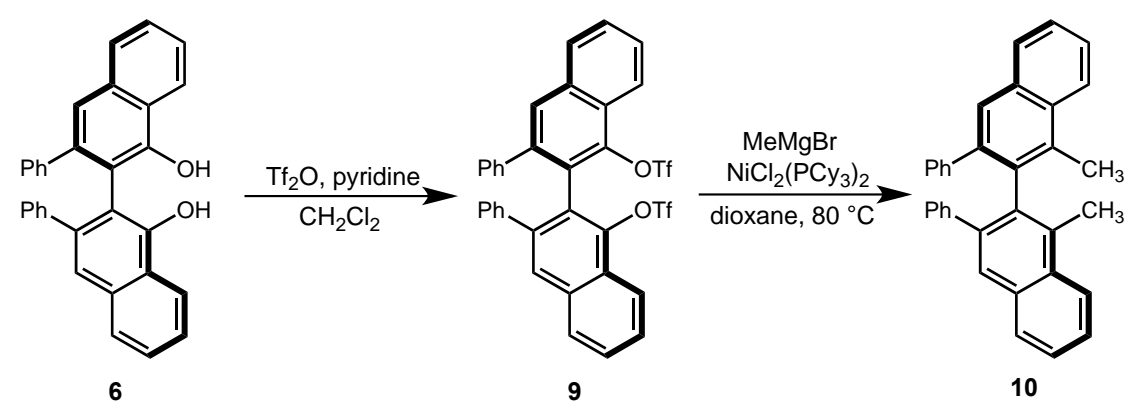

(S)-3,3'-diphenyl-[2,2'-binaphthalene]-1,1'-diyl bis(trifluoromethanesulfonate) (9): To a

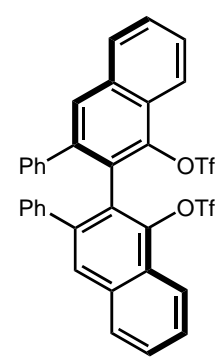
flame dried round bottom flask was added $(S)$-VANOL (6) $(1.0 \mathrm{~g}, 6.84 \mathrm{mmol}, 1.0$ equiv.), $\mathrm{CH}_{2} \mathrm{Cl}_{2}(15 \mathrm{~mL}$ ) and pyridine $(3.3 \mathrm{~mL}, 41.1 \mathrm{mmol}, 6.0$ equiv.).The flask was cooled to $0{ }^{\circ} \mathrm{C}$ and trifluoromethanesulfonic anhydride $(4.6 \mathrm{~mL}, 27.4 \mathrm{mmol}$, 4.0 equiv.) was added slowly. The reaction was the let warm to $23{ }^{\circ} \mathrm{C}$ and stir overnight. The reaction flask was then cooled to $0{ }^{\circ} \mathrm{C}$, quenched with $2 \mathrm{M} \mathrm{HCl}_{(\mathrm{aq}}$, and extracted with $\mathrm{CH}_{2} \mathrm{Cl}_{2}(3 \mathrm{x})$. The combined organic layers were washed $2 \mathrm{M}$ $\mathrm{HCl}_{(\mathrm{aq})}$, brine, dried with $\mathrm{Na}_{2} \mathrm{SO}_{4}$, and concentrated in vacuo. The resulting residue was partially purified via flash column chromatography on silica gel (90:10 hexanes: $\mathrm{CH}_{2} \mathrm{Cl}_{2}$ to $85: 15$ hexanes: $\mathrm{CH}_{2} \mathrm{Cl}_{2}$ ). The resulting yellow solid was then triturated with hexanes to afford the title compound as a white solid $(4.1 \mathrm{~g}, 5.8 \mathrm{mmol}, 85 \%)$. ${ }^{1} \mathrm{H}$ NMR (400 $\left.\mathrm{MHz}, \mathrm{CDCl}_{3}\right) \delta 8.34(\mathrm{~d}, J=8.4 \mathrm{~Hz}, 2 \mathrm{H}), 7.92(\mathrm{~d}, J=8.1 \mathrm{~Hz}, 2 \mathrm{H}), 7.66-7.77(\mathrm{~m}, 6 \mathrm{H}), 7.09-7.13$ $(\mathrm{m}, 2 \mathrm{H}), 6.92-6.96(\mathrm{~m}, 4 \mathrm{H}), 6.61-6.63(\mathrm{~m}, 4 \mathrm{H}) ;{ }^{13} \mathrm{C} \mathrm{NMR}\left(100 \mathrm{MHz}, \mathrm{CDCl}_{3}\right) \delta 144.8,140.7$, $139.2,134.8,130.5,129.1,128.6,128.4,128.0,126.9,126.7,124.5,121.9,118.2\left(\mathrm{q}, J_{\mathrm{CF}}=318.7\right.$ $\mathrm{Hz}$ ); IR (neat) 3054, 2949, 2154, 1736, 1701, 1625, 1591, 1491, 1274, 1132, 796, $699 \mathrm{~cm}^{-1} ; \mathrm{mp}$ 191-194 ${ }^{\circ} \mathrm{C}$; HRMS (ESI): Mass calculated for $\mathrm{C}_{34} \mathrm{H}_{20} \mathrm{~F}_{6} \mathrm{O}_{6} \mathrm{~S}_{2} \mathrm{Na}^{+}[\mathrm{M}+\mathrm{Na}]^{+}, 725.0498$ Found $[\mathrm{M}+\mathrm{Na}]^{+}, 725.0472 ;[\alpha]^{23}{ }_{\mathrm{D}}=-18.3\left(\mathrm{c} 0.68, \mathrm{CHCl}_{3}\right)$.

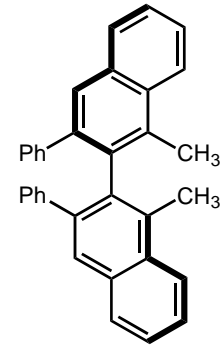

(S)-1,1'-dimethyl-3,3'-diphenyl-2,2'-binaphthalene (10): To a flame dried twoneck round bottom flask was added $9(500 \mathrm{mg}, 0.71 \mathrm{mmol}$, 1.0 equiv.) and $\mathrm{NiCl}_{2}\left(\mathrm{PCy}_{3}\right)_{2}(49 \mathrm{mg}, 0.071 \mathrm{mmol}, 0.1$ equiv.). The flask was then equipped with a condenser and the reaction system was purged with a continuous flow of $\mathrm{N}_{2}$. After the reaction system was under $\mathrm{N}_{2}$ atmosphere, freshly distilled and degassed 1,4dioxane $(3.5 \mathrm{~mL})$ was added. The reaction flask was cooled to $0{ }^{\circ} \mathrm{C}$ and $\mathrm{MeMgBr}$ (3.0 $\mathrm{M}$ in $\mathrm{Et}_{2} \mathrm{O}, 0.94 \mathrm{~mL}, 2.84 \mathrm{mmol}, 4.0$ equiv.) was added slowly. The top of the condenser was then equipped with a vent needle and the reaction system was gradually heated to $80{ }^{\circ} \mathrm{C}$ allowing for the $\mathrm{Et}_{2} \mathrm{O}$ from the $\mathrm{MeMgBr}$ solution to evaporate out of the reaction system. The reaction was then stirred overnight at $80{ }^{\circ} \mathrm{C}$. The reaction flask was cooled to $0{ }^{\circ} \mathrm{C}$ and $2 \mathrm{M} \mathrm{HCl}_{(\mathrm{aq})}$ was added slowly to quench the reaction. The reaction was then diluted with $\mathrm{H}_{2} \mathrm{O}$ and extracted with $\mathrm{Et}_{2} \mathrm{O}(3 \mathrm{x})$. The combined organic layers were washed with brine, dried with $\mathrm{Na}_{2} \mathrm{SO}_{4}$, and concentrated in vacuo. The resulting residue was then run through a large silica plug using $\mathrm{CH}_{2} \mathrm{Cl}_{2}$ as the eluent and concentrated in vacuo. The crude material was resubjected to the exact same reaction conditions as stated above. After performing the same work-up procedure, the resulting residue was partially purified via flash column chromatography 
on silica gel (hexanes to 99:1 hexanes:Et ${ }_{2} \mathrm{O}$ ) to give slightly impure 10 (138 mg) (See ${ }^{1} \mathrm{H}-\mathrm{NMR}$ below). The material was then used as is for the next synthetic sequence.

\section{Synthesis of 5d:}

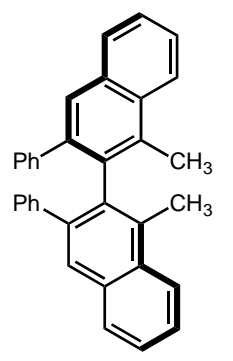

10

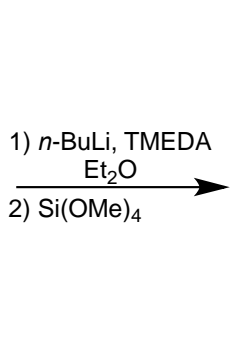

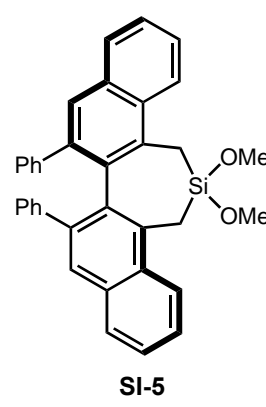
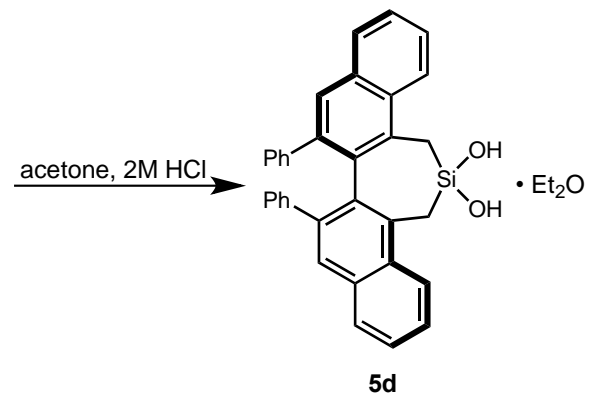

$5 d$

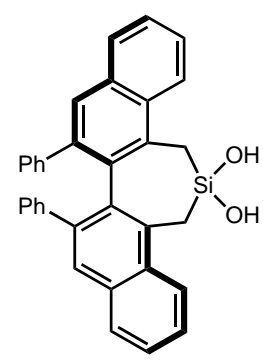

(S)-9,10-diphenyl-1,3-dihydro-2H-dinaphtho[1,2-c:2',1'-e]silepine-2,2-diol (5d): To a flame dried vial was added partially impure $10(138 \mathrm{mg}, 0.32 \mathrm{mmol}$, 1.0 equiv.) and $\mathrm{Et}_{2} \mathrm{O}(2.5 \mathrm{~mL})$. The vial was cooled to $0{ }^{\circ} \mathrm{C}$ and TMEDA $(0.19$ $\mathrm{mL}, 1.28 \mathrm{mmol}, 4.0$ equiv.) was added followed by the addition of $n$-BuLi (2.5 $\mathrm{M}$ in $\mathrm{Et}_{2} \mathrm{O}, 0.51 \mathrm{~mL}, 1.28 \mathrm{mmol}, 4.0$ equiv.). The reaction was warmed to $23{ }^{\circ} \mathrm{C}$ and allowed to stir for $9 \mathrm{~h}$. After $9 \mathrm{~h}, \mathrm{Si}(\mathrm{OMe})_{4}(0.24 \mathrm{~mL}, 1.6 \mathrm{mmol}, 5.0$ equiv.) was added and the reaction was stirred for $18 \mathrm{~h}$ at $23{ }^{\circ} \mathrm{C}$. The reaction mixture was then filtered through Celite using $\mathrm{Et}_{2} \mathrm{O}$ as the eluent and concentrated in vacuo. The material was subjected to flash column chromatography on silica gel (hexanes to 99:1 hexanes:Et $\left.{ }_{2} \mathrm{O}\right)$ to give slightly impure SI-5 $(20 \mathrm{mg}$ ) and used in the next step of the synthetic sequence.

To a flame dried vial was added SI-5 $(20 \mathrm{mg})$, acetone $(1.4 \mathrm{~mL})$ and $2 \mathrm{M} \mathrm{HCl}_{(\mathrm{aq})}(0.4$ $\mathrm{mL})$. The reaction was then stirred overnight. The vial was then diluted with $\mathrm{Et}_{2} \mathrm{O}(1 \mathrm{~mL})$ and neutralized to $\mathrm{pH} 7$ using saturated $\mathrm{NaHCO}_{3(\mathrm{aq})}$ and then extracted with $\mathrm{Et}_{2} \mathrm{O}$ (3x). The combined organic layers were washed with brine, dried with $\mathrm{Na}_{2} \mathrm{SO}_{4}$, and concentrated in vacuo. The resulting residue was purified via flash column chromatography on silica gel (80:20 hexanes: $\mathrm{Et}_{2} \mathrm{O}$ to $20: 80$ hexanes $\left.\mathrm{Et}_{2} \mathrm{O}\right)$ to afford the title compound as an off-white solid (10.1 $\mathrm{mg}, 0.02 \mathrm{mmol}, 3 \%$ over three steps). The silanediol exists as a $2: 1$ complex with $\mathrm{Et}_{2} \mathrm{O} .{ }^{1} \mathrm{H} \mathrm{NMR}$ $\left(400 \mathrm{MHz} \mathrm{CDCl}_{3}\right) \delta 8.21(\mathrm{~d}, J=8.5 \mathrm{~Hz}, 2 \mathrm{H}), 7.80(\mathrm{~d}, J=8.1 \mathrm{~Hz}, 2 \mathrm{H}), 7.57-7.61(\mathrm{~m}, 2 \mathrm{H}), 7.49$ $7.53(\mathrm{~m}, 2 \mathrm{H}), 7.42(\mathrm{~s}, 2 \mathrm{H}), 7.02-7.06(\mathrm{~m}, 2 \mathrm{H}), 6.88-6.92(\mathrm{~m}, 4 \mathrm{H}), 6.43-6.45(\mathrm{~m}, 4 \mathrm{H}), 3.08(\mathrm{~d}, J=$ $13.9 \mathrm{~Hz}, 2 \mathrm{H}), 2.37-2.41(\mathrm{~m}, 4 \mathrm{H}) ;{ }^{13} \mathrm{C} \mathrm{NMR}\left(150 \mathrm{MHz}, \mathrm{CDCl}_{3}\right) \delta 141.3,139.8,135.5,134.1$, 133.6, 130.5, 129.6, 129.2, 127.3, 126.4, 126.2, 126.0, 124.2, 17.5; IR (neat) 3515, 3054, 2984, 1735, 1701, 1493, 1264, 1133, 736, $704 \mathrm{~cm}^{-1}$; mp 257-260 ${ }^{\circ} \mathrm{C}$; HRMS (ESI): Mass calculated for $\mathrm{C}_{34} \mathrm{H}_{26} \mathrm{O}_{2} \mathrm{SiNa}^{+}[\mathrm{M}+\mathrm{Na}]^{+}, 517.1594$ Found $[\mathrm{M}+\mathrm{Na}]^{+}, 517.1588 ;[\alpha]^{23}=-84.1\left(\mathrm{c} 0.29, \mathrm{CHCl}_{3}\right)$. 


\section{Synthesis of 5e:}

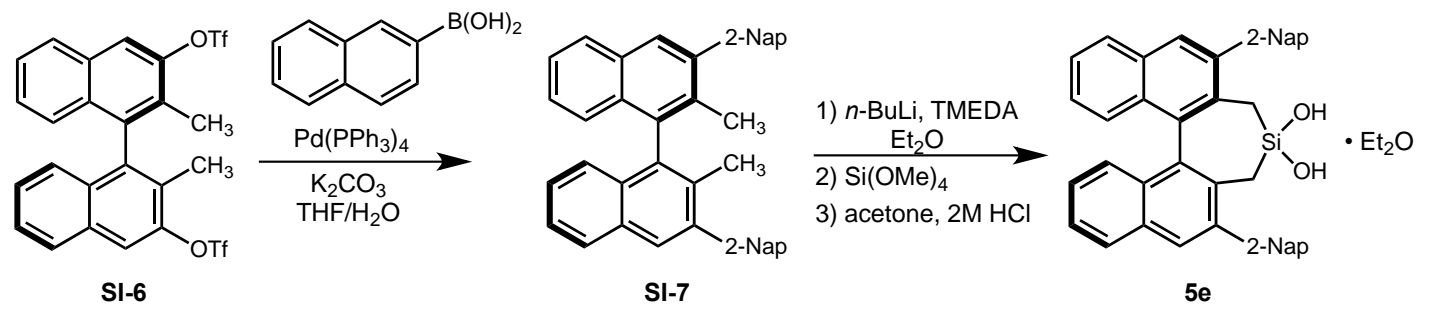

(R)-2,6-di(naphthalen-2-yl)-3,5-dihydro-4H-dinaphtho[2,1-c:1',2'-e]silepine-4,4-diol (5e): 2-Nap SI-6 was prepared according to a known synthetic sequence. ${ }^{2}$ To a flame dried round bottom flask was added SI-6 (3.50 g, $6.05 \mathrm{mmol}, 1.0$ equiv.), 2naphthylboronic acid (2.50 g, $14.52 \mathrm{mmol}, 2.4$ equiv.), $\mathrm{Pd}\left(\mathrm{PPh}_{3}\right)_{4}(699 \mathrm{mg}$, 0.605 mmol, 0.1 equiv.) and $\mathrm{K}_{2} \mathrm{CO}_{3}(5.02 \mathrm{~g}, 36.3 \mathrm{mmol}, 6.0$ equiv.). The reagents were dissolved in THF $(25 \mathrm{~mL})$ and $\mathrm{H}_{2} \mathrm{O}(25 \mathrm{~mL})$ and the reaction was refluxed overnight. The reaction was then cooled to $23{ }^{\circ} \mathrm{C}$ and diluted with $\mathrm{H}_{2} \mathrm{O}(50 \mathrm{~mL})$ and extracted with $\mathrm{Et}_{2} \mathrm{O}(3 \mathrm{x})$. The combined organic layers were washed with brine, dried with $\mathrm{Na}_{2} \mathrm{SO}_{4}$, and concentrated in vacuo. The resulting solid was subjected to subjected to flash column chromatography on silica gel (hexanes to $95: 5$ hexanes: $\mathrm{Et}_{2} \mathrm{O}$ ) to give SI-7 and was used directly in the next reaction.

To a flame dried round bottom flask was added SI-7, $\mathrm{Et}_{2} \mathrm{O}(90 \mathrm{~mL})$, and TMEDA (4.5

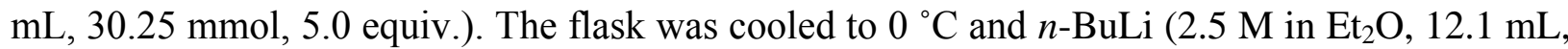
$30.25 \mathrm{mmol}, 5.0$ equiv.) was slowly added. The reaction was warmed to $23{ }^{\circ} \mathrm{C}$ and allowed to stir for $24 \mathrm{~h}$. After $24 \mathrm{~h}, \mathrm{Si}(\mathrm{OMe})_{4}(8.9 \mathrm{~mL}, 60.5 \mathrm{mmol}, 10.0$ equiv. $)$ was added and the reaction was stirred overnight at $23{ }^{\circ} \mathrm{C}$. The reaction mixture was then filtered through Celite using $\mathrm{Et}_{2} \mathrm{O}$ as the eluent and concentrated in vacuo. The material was run through a large silica gel plug using $\mathrm{Et}_{2} \mathrm{O}$ as the eluent, concentrated and then subjected to flash column chromatography on silica gel (hexanes to $80: 20$ hexanes: $\mathrm{Et}_{2} \mathrm{O}$ ) to give $1.26 \mathrm{~g}$ of crude product, which was used directly in the next synthetic step.

To a flame dried round bottom flask was added crude material $(1.26 \mathrm{~g})$ and acetone (225 $\mathrm{mL}$ ), then the reaction was cooled to $0{ }^{\circ} \mathrm{C} .2 \mathrm{M} \mathrm{HCl}_{(\mathrm{aq})}$ was added slowly and the reaction was allowed to warm to $23{ }^{\circ} \mathrm{C}$ and stir overnight. The flask was then diluted with $\mathrm{Et}_{2} \mathrm{O}$ and neutralized to $\mathrm{pH} 7$ using saturated $\mathrm{NaHCO}_{3(\mathrm{aq})}$ and then extracted with $\mathrm{Et}_{2} \mathrm{O}(3 \mathrm{x})$. The combined organic layers were washed with brine, dried with $\mathrm{Na}_{2} \mathrm{SO}_{4}$, and concentrated in vacuo. The resulting residue was purified via flash column chromatography on silica gel (90:10 hexanes: $\mathrm{Et}_{2} \mathrm{O}$ to $60: 40$ hexanes $\mathrm{Et}_{2} \mathrm{O}$ ) to afford the title compound as a white solid (742 mg, 1.25 mmol, $21 \%$ over three steps). The silanediol exists as a 2:1 complex with $\mathrm{Et}_{2} \mathrm{O} .{ }^{1} \mathrm{H}$ NMR (400 $\left.\mathrm{MHz}, \mathrm{CDCl}_{3}\right) \delta$ 7.79-7.97 (m, 12H), $7.64(\mathrm{~d}, J=8.2 \mathrm{~Hz}, 2 \mathrm{H}), 7.42-7.47(\mathrm{~m}, 4 \mathrm{H}), 7.36-7.40(\mathrm{~m}$, $2 \mathrm{H}), 7.24-7.28(\mathrm{~m}, 2 \mathrm{H}), 7.15-7.17(\mathrm{~m}, 2 \mathrm{H}), 2.26(\mathrm{~d}, J=13.8 \mathrm{~Hz}, 2 \mathrm{H}), 2.18(\mathrm{~s}, 2 \mathrm{H}), 1.86(\mathrm{~d}, J=$ $13.8 \mathrm{~Hz}, 2 \mathrm{H}) ;{ }^{13} \mathrm{C} \mathrm{NMR}\left(100 \mathrm{MHz}, \mathrm{CDCl}_{3}\right) \delta 140.2,139.8,134.2,133.4,133.0,132.42,132.41$, 131.6, 129.2, 128.6, 128.4, 128.1, 128.0, 127.7, 126.6, 126.5, 126.2, 125.3, 18.9; IR (neat) 3422, 3056, 2981, 2952, 2249, 1731, 1701, 1626, 1493, 1275, 908, $749 \mathrm{~cm}^{-1}$; mp 301-305 ${ }^{\circ} \mathrm{C}$; HRMS (ESI): Mass calculated for $\mathrm{C}_{42} \mathrm{H}_{30} \mathrm{O}_{2} \mathrm{SiNa}^{+}[\mathrm{M}+\mathrm{Na}]^{+}, 617.1907$ Found $[\mathrm{M}+\mathrm{Na}]^{+}, 617.1916 ;[\alpha]^{23}$ $=-79.5\left(\mathrm{c} 0.44, \mathrm{CHCl}_{3}\right)$. 


\section{General Procedure for the Preparation of Silyl Ketene Acetals}
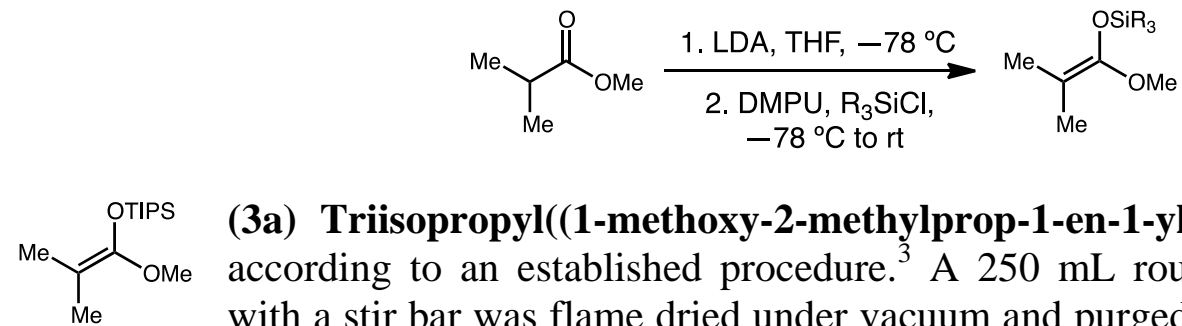

(3a) Triisopropyl((1-methoxy-2-methylprop-1-en-1-yl)oxy)silane was prepared according to an established procedure. ${ }^{3}$ A $250 \mathrm{~mL}$ round bottom flask equipped with a stir bar was flame dried under vacuum and purged with $\mathrm{N}_{2}(\mathrm{~g})$. The flask was placed under positive pressure of argon gas and fitted with a rubber septa. The reaction vessel was charged with $50 \mathrm{~mL}$ of anhydrous THF and diisopropyl amine $(4.2 \mathrm{~mL}, 30 \mathrm{mmol}, 1.2$ equiv), and cooled to $0^{\circ} \mathrm{C}$. A solution of $1.3 \mathrm{M} \mathrm{n}$-BuLi (21.2 mL, $27.5 \mathrm{mmol}, 1.1$ equiv) in hexanes was added dropwise to the reaction mixture and stirred for 20 minutes at $0{ }^{\circ} \mathrm{C}$. The reaction was cooled to $-78{ }^{\circ} \mathrm{C}$ and methyl isobutyrate $(2.87 \mathrm{~mL}, 25 \mathrm{mmol}, 1.0$ equiv) was added over a 10-minute period. The reaction was stirred for $30 \mathrm{mins}$ at $-78^{\circ} \mathrm{C}$, followed by the addition 1,3-dimethyl-3,4,5,6-tetrahydro-2(1H)-pyrimidinone (DMPU) $(4.53 \mathrm{~mL}, 37.5 \mathrm{mmol}, 1.5$ equiv) and triisopropylsilyl chloride $\left(6.42 \mathrm{~mL}, 30 \mathrm{mmol}, 1.2\right.$ equiv). The reaction stirred at $-78{ }^{\circ} \mathrm{C}$ for $30 \mathrm{~min}$ then warmed to room temperature for $1 \mathrm{~h}$. Solvent was removed under reduced pressure and the resulting mixture was taken up in $200 \mathrm{~mL}$ of pentane, washed sequentially with water (1 x $100 \mathrm{~mL})$, saturated CuSO4 (1 x $100 \mathrm{~mL})$, saturated $\mathrm{NaHCO}_{3}(1 \times 100 \mathrm{~mL})$, and brine $(1 \times 100$ $\mathrm{mL}$ ). The organic layer was dried over anhydrous $\mathrm{Na}_{2} \mathrm{SO}_{4}$, and concentrated under reduced pressure, resulting in an oil which was purified via fractional distillation to yield the title compound (5.62 g, $21.7 \mathrm{mmol}, 87 \%$ yield) as a clear colorless liquid. ${ }^{1} \mathrm{H}$ NMR (400 MHz, $\left.\mathrm{CDCl}_{3}\right): \delta 3.56(\mathrm{~s}, 3 \mathrm{H}), 1.57(\mathrm{~s}, 6 \mathrm{H}), 1.09-1.18(21 \mathrm{H})$. All spectral data matched that previously reported. ${ }^{4}$

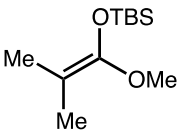

(3b) tert-Butyl((1-methoxy-2-methylprop-1-en-1-yl)oxy)dimethylsilane Using the method above, the title compound (4.04 g, $18.7 \mathrm{mmol}, 75 \%$ yield) was obtained as a clear colorless liquid. ${ }^{1} \mathrm{H}$ NMR $\left(400 \mathrm{MHz}, \mathrm{CDCl}_{3}\right): \delta 3.51(\mathrm{~s}, 3 \mathrm{H}), 1.57(\mathrm{~s}, 3 \mathrm{H})$, $1.53(\mathrm{~s}, 3 \mathrm{H}), 0.96(\mathrm{~s}, 9 \mathrm{H}), 0.14(\mathrm{~s}, 6 \mathrm{H})$. All spectral data matched that previously reported. ${ }^{5}$

\section{General Procedure for the Preparation of Chromenones}

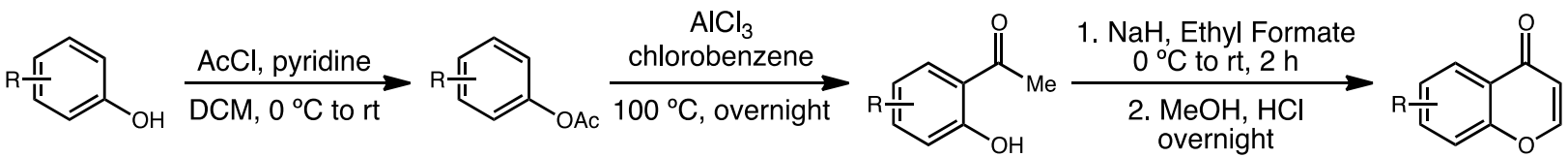<smiles>CC(=O)Oc1ccccc1</smiles>

Phenols were purchased and used as received. The corresponding phenol was dissolved in dichloromethane $(1.3 \mathrm{M})$ in a flame-dried flask that was cooled to 0 ${ }^{\circ} \mathrm{C}$. Pyridine (1.3 eq) was added to the flask immediately followed by acetyl chloride $(1.2 \mathrm{eq})$. The flask was warmed to room temperature and the reaction mixture stirred until complete as indicated by TLC (approx. 3 hours). The reaction mixture was washed with water, $3 \mathrm{M} \mathrm{HCl}$ (aq), water, $\mathrm{NaHCO}_{3}$ (sat. aq) and finally dried with $\mathrm{Na}_{2} \mathrm{SO}_{4}$. The solvent was removed under reduced pressure and pure material was isolated after column chromatography in nearly quantitative yield. ${ }^{6}$ 


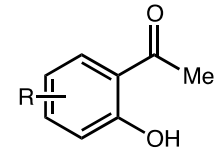

2'-hydroxyacetophenones were either purchased and used as received or synthesized according to a modified procedure. ${ }^{6}$ Acylated phenols were dissolved in a flame-dried flask in chlorobenzene $(0.8 \mathrm{M})$. The flask was fitted with a septum and a positive flow of nitrogen with a vent needle flowing into a flask of $\mathrm{NaHCO}_{3}$ (sat. aq) to quench any $\mathrm{HCl}$ gas released during the course of the reaction. The flask was cooled to $0{ }^{\circ} \mathrm{C}$ and aluminum trichloride was slowly added in portions. After the addition, the flask was placed in an oil bath and slowly warmed to $100{ }^{\circ} \mathrm{C}$ and allowed to stir overnight. Then, the reaction was cooled to room temperature, dichloromethane added to solubilize the mixture, and the flask cooled to ${ }^{\circ} \mathrm{C}$. Cold $3 \mathrm{M} \mathrm{HCl}$ was added drop wise to quench the reaction which was then future diluted with dichloromethane. The organic phase was washed with water, dried with $\mathrm{Na}_{2} \mathrm{SO}_{4}$, and solvent removed. The pure acetophenone was isolated via flash column chromatography.

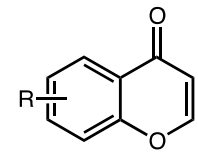

Chromenones were prepared according to a modified procedure or purchased and used as received. ${ }^{7}$ The corresponding 2'-hydroxyacetophenone (1 eq) was placed in a flame-dried flask with stir bar in $0.5 \mathrm{M}$ ethyl formate and cooled to $0{ }^{\circ} \mathrm{C}$. $\mathrm{NaH}$ (60\% in mineral oil, $6 \mathrm{eq}$ ) was added portion-wise to the cooled solution over 2 hours. If necessary for stirring, minimal amounts of dry THF were added to the flask in portions as needed. After addition of all of the $\mathrm{NaH}$, the solution was warmed to room temperature and quenched with methanol (10 eq). Concentrated $\mathrm{HCl}(50 \mathrm{eq})$ was then added slowly and allowed to stir overnight at room temperature. The reaction was then diluted with ethyl acetate, washed with water, $\mathrm{NaHCO}_{3}$ (sat. aq.), and brine, dried with $\mathrm{Na}_{2} \mathrm{SO}_{4}$, and concentrated under vacuum to afford the crude chromenone. The chromenones were then recrystallized with ethyl acetate/hexanes or dichloromethane/hexanes to afford pure material.

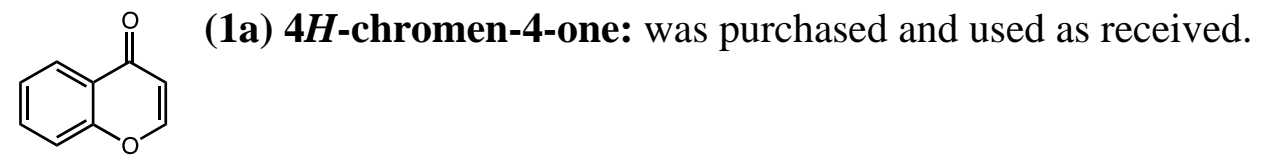<smiles>O=c1ccoc2ccc(Cl)cc12</smiles>

(1b) 6-chloro-4H-chromen-4-one: was purchased and used as received.<smiles>O=c1ccoc2ccc(Br)cc12</smiles>

(1c) 6-bromo-4H-chromen-4-one: was synthesized from the 2'-1-(5-bromo-2hydroxyphenyl)ethanone (purchased) $(25 \mathrm{mmol})$ according to the standard procedure above. $4.75 \mathrm{~g}$ (84\% yield) of pure chromenone was isolated as a white solid via recrystallization from ethyl acetate/hexanes. All spectral data matched previous reports. ${ }^{8}{ }^{1} \mathrm{H}$ NMR $\left(400 \mathrm{MHz}, \mathrm{CDCl}_{3}\right) \delta 8.33(\mathrm{~d}, J=2.4 \mathrm{~Hz}, 1 \mathrm{H}), 7.85(\mathrm{~d}, J=6 \mathrm{~Hz}, 1 \mathrm{H})$, $7.75(\mathrm{dd}, J=8.8,2.4 \mathrm{~Hz}, 1 \mathrm{H}), 7.36(\mathrm{~d}, J=8.8 \mathrm{~Hz}, 1 \mathrm{H}), 6.35(\mathrm{~d}, J=6.4 \mathrm{~Hz}, 1 \mathrm{H}) ;{ }^{13} \mathrm{C} \mathrm{NMR}(100$ $\left.\mathrm{MHz}, \mathrm{CDCl}_{3}\right) \delta 176.3,155.5,155.4,136.9,128.6,126.3,120.3,118.9,113.2$. 
<smiles>O=c1ccoc2ccc(-c3cc(C(F)(F)F)cc(C(F)(F)F)c3)cc12</smiles>

(1d) 6-(3,5-bis(trifluoromethyl)phenyl)-4H-chromen-4-one: Compound 1c was subjected to typical Suzuki coupling conditions: 1c $(250 \mathrm{mg}, 1.11$ mmol, $1 \mathrm{eq}$ ), 3,5-bis(trifluoromethyl)phenyl boronic acid (343 mg, 1.33 mmol, $1.2 \mathrm{eq}), \mathrm{Pd}\left(\mathrm{PPh}_{3}\right)_{4}(65 \mathrm{mg}, 0.056 \mathrm{mmol}, 0.05 \mathrm{eq})$, and $\mathrm{K}_{2} \mathrm{CO}_{3}(920$ $\mathrm{mg}, 6.66 \mathrm{mmol}, 6 \mathrm{eq})$ were dissolved in $\mathrm{H}_{2} \mathrm{O}(5 \mathrm{~mL})$ and THF $(5 \mathrm{~mL})$ and refluxed overnight. After cooling, the mixture was diluted with $2 \mathrm{M} \mathrm{HCl} \mathrm{(aq),} \mathrm{extracted} \mathrm{with}$ diethyl ether $(20 \mathrm{~mL} \times 3)$, washed with brine $(20 \mathrm{~mL})$, and dried with $\mathrm{Na}_{2} \mathrm{SO}_{4}$. After removal of the solvent under reduced pressure, crude 1d was isolated after silica gel flash column chromatography ( $100 \%$ hexanes to $20 \%$ ethyl acetate: hexanes). 1d was isolated as a white solid in $65 \%$ yield $(260 \mathrm{mg}) . \mathrm{Mp} 190-195{ }^{\circ} \mathrm{C}$; $1 \mathrm{H} \mathrm{NMR}\left(400 \mathrm{MHz}, \mathrm{CDCl}_{3}\right) \delta 8.46(\mathrm{~d}, J=2.4 \mathrm{~Hz}, 1 \mathrm{H})$, $8.08(\mathrm{~s}, 2 \mathrm{H}), 7.94-7.90(\mathrm{~m}, 3 \mathrm{H}), 7.62(\mathrm{~d}, J=8.8 \mathrm{~Hz}, 1 \mathrm{H}), 6.42(\mathrm{~d}, J=6.4,1 \mathrm{H}) ;{ }^{13} \mathrm{C}$ NMR $(100$ $\left.\mathrm{MHz}, \mathrm{CDCl}_{3}\right) \delta 177.3,156.8,155.6,141.5,135.5,132.6\left(\mathrm{q}, J_{\mathrm{CF}}=333 \mathrm{~Hz}\right), 132.5,127.4,125.4$, $124.5,123.3\left(\mathrm{q}, J_{\mathrm{CF}}=270 \mathrm{~Hz}\right), 121.7\left(\mathrm{p}, J_{\mathrm{CF}}=37 \mathrm{~Hz}\right), 119.6,113.4$. IR: 3063, 2981, 1655, 1615, 1472, 1379, 1276, 1162, 1133, 1114, 1083, 897, 832, $680 \mathrm{~cm}^{-1}$; HRMS (ESI): Mass calculated for $\mathrm{C}_{17} \mathrm{H}_{8} \mathrm{~F}_{6} \mathrm{NaO}_{2}{ }^{+}[\mathrm{M}+\mathrm{Na}]^{+} 381.0321$, Found $[\mathrm{M}+\mathrm{Na}]^{+} 381.0312$.<smiles>COc1ccc([N+](=O)[O-])cc1C(=O)CO</smiles>

(1e) 6-nitro-4H-chromen-4-one: was purchased and used as received.<smiles>O=c1ccoc2ccc(F)cc12</smiles>

(1f) 6-fluoro-4H-chromen-4-one: was synthesized from the 2'-1-(5-fluoro-2hydroxyphenyl)ethanone (purchased) $(10 \mathrm{mmol})$ according to the standard procedure above. Observed spectral data matched previous reports. ${ }^{9} 0.902 \mathrm{~g}(55 \%$ yield first crop) of pure chromenone was isolated as a white solid via recrystallization from DCM/hexanes. Mp 163-166 ${ }^{\circ} \mathrm{C} ;{ }^{1} \mathrm{H}$ NMR $\left(400 \mathrm{MHz}, \mathrm{CDCl}_{3}\right) \delta 7.86-7.83$ $(\mathrm{m}, 2 \mathrm{H}), 7.49-7.45(\mathrm{~m}, 1 \mathrm{H}), 7.42-7.37(\mathrm{~m}, 1 \mathrm{H}), 6.33(\mathrm{~d}, J=6 \mathrm{~Hz}, 1 \mathrm{H}) ;{ }^{13} \mathrm{C} \mathrm{NMR}(100 \mathrm{MHz}$, $\left.\mathrm{CDCl}_{3}\right) \delta 176.8\left(\mathrm{~d}, J_{\mathrm{CF}}=2 \mathrm{~Hz}\right), 159.6\left(\mathrm{~d}, J_{\mathrm{CF}}=247 \mathrm{~Hz}\right), 155.5,152.8\left(\mathrm{~d}, J_{\mathrm{CF}}=2 \mathrm{~Hz}\right), 126.1(\mathrm{~d}$, $\left.J_{\mathrm{CF}}=7 \mathrm{~Hz}\right), 122.1\left(\mathrm{~d}, J_{\mathrm{CF}}=25 \mathrm{~Hz}\right), 120.4(J=8 \mathrm{~Hz}), 112.3,110.7(\mathrm{~d}, J=24 \mathrm{~Hz}) ; \mathrm{IR}: 3084$, 3037, 1640, 1617, 1574, 1478, 1397, 1313, 1202, 1170, 1134, 1026, 918, 893, 704, $548 \mathrm{~cm}^{-1}$; HRMS (ESI): Mass calculated for $\mathrm{C}_{9} \mathrm{H}_{5} \mathrm{FNaO}_{2}^{+}[\mathrm{M}+\mathrm{Na}]^{+}$187.0166, Found [M+Na] $]^{+}$187.0166.<smiles>Cc1ccc2occc(=O)c2c1</smiles>

(1g) 6-methyl-4H-chromen-4-one: was synthesized according to a known procedure similar to the general procedure above. ${ }^{10} \mathrm{p}$-cresol $(1 \mathrm{eq}, 10 \mathrm{mmol})$ was dissolved in dry toluene $(2 \mathrm{~mL}, 5 \mathrm{M})$ in a flame-dried flask and cooled to $0{ }^{\circ} \mathrm{C}$. Acetyl chloride $(0.711 \mathrm{~mL}, 10 \mathrm{mmol}, 1 \mathrm{eq})$ was added slowly. After stirring for 5 minutes, a positive flow of nitrogen with a vent needle flowing into a flask of $\mathrm{NaHCO}_{3}$ (sat. aq) to quench any $\mathrm{HCl}$ gas released during the course of the reaction. $\mathrm{AlCl}_{3}(2.67 \mathrm{~g}, 20 \mathrm{mmol}, 2 \mathrm{eq})$ was added in portions to the cooled reaction mixture. The flask was then warmed to $120^{\circ} \mathrm{C}$ and heated for 10 hours. After this time, the flask was cooled to room and hydrolyzed with crushed ice. The organic layer was extracted with dichloromethane and dried with $\mathrm{Na}_{2} \mathrm{SO}_{4}$. After the solvent was removed under reduced pressure, the pure 1-(2-hydroxy-5-methylphenyl)ethanone $(0.470 \mathrm{~g}, 32 \%$ yield) was isolated via silica gel flash column chromatography $(100 \%$ hexanes to $80 / 20$ hexanes/ethyl ether). Spectral data matched previous reports. Mp 80-82 ${ }^{\circ} \mathrm{C} ;{ }^{1} \mathrm{H}$ NMR $(400$ $\left.\mathrm{MHz} \mathrm{CDCl}_{3}\right) \delta 12.08(\mathrm{~s}, 1 \mathrm{H}), 7.29(\mathrm{dd}, J=8.4,1.6 \mathrm{~Hz}, 1 \mathrm{H}), 6.88(\mathrm{~d}, J=8.4 \mathrm{~Hz}, 1 \mathrm{H}), 2.62(\mathrm{~s}$, 
3H), 2.31 (s, 3H); 1-(2-hydroxy-5-methylphenyl)ethanone (1.33 g, $8.85 \mathrm{mmol})$ was then subjected to the general chromenone formation procedure as stated above. 6-methyl-4Hchromen-4-one was isolated as a white solid from recrystallization with dichloromethane/hexanes (1.03 g, 72\% yield). ${ }^{1} \mathrm{H}$ NMR (400 MHz, $\left.\mathrm{CDCl}_{3}\right) \delta 7.98(\mathrm{~s}, 1 \mathrm{H}), 7.82$ $(\mathrm{dd}, J=6,1.2 \mathrm{~Hz}, 1 \mathrm{H}), 7.47-7.45(\mathrm{~m}, 1 \mathrm{H}), 7.34(\mathrm{dd}, J=8.8,2 \mathrm{~Hz}, 1 \mathrm{H}), 6.30(\mathrm{dd}, J=6.3 .2 \mathrm{~Hz}$, 1H) $2.44(\mathrm{~s}, 3 \mathrm{H}) ;{ }^{13} \mathrm{C}$ NMR $\left(100 \mathrm{MHz}, \mathrm{CDCl}_{3}\right) \delta 177.7,155.1,154.8,135.2,134.9,125.1,124.5$, 117.9, 112.8, 20.9; IR: 2980, 2915, 1644, 1620, 1480, 1431, 1314, 1198, 835, $809 \mathrm{~cm}^{-1}$; HRMS (ESI): Mass calculated for $\mathrm{C}_{10} \mathrm{H}_{8} \mathrm{NaO}_{2}^{+}[\mathrm{M}+\mathrm{Na}]^{+}$183.0417, Found $[\mathrm{M}+\mathrm{Na}]^{+}$183.0416.<smiles>O=c1ccoc2cc(C(F)(F)F)ccc12</smiles>
(trifluoromethyl)benzoic acid (1.0 g, $4.85 \mathrm{mmol}, 1 \mathrm{eq})$ was dissolved in $10 \mathrm{~mL}$ dry THF in a flame dried flask. The flask was cooled to $0{ }^{\circ} \mathrm{C}$ and MeLi (1.6 M in ether, $10.3 \mathrm{~mL}, 16.49 \mathrm{mmol}, 3.4 \mathrm{eq}$ ) was added dropwise. The mixture was allowed to come to room temperature and stir overnight. The solution was diluted with $10 \mathrm{~mL}$ of EtOAc and cooled to $0{ }^{\circ} \mathrm{C}$. $10 \mathrm{~mL}$ of $12 \mathrm{M} \mathrm{HCl}$ was added to the flask. The solution was extracted with EtOAc $\left(20 \mathrm{~mL}\right.$ x 3), washed with brine $(20 \mathrm{~mL})$, and dried with $\mathrm{Na}_{2} \mathrm{SO}_{4}$. After removal of the solvent under reduced pressure. The residue was isolated after silica gel flash plug with 100\% EtOAc to afford the 1-(2-hydroxy-4-(trifluoromethyl)phenyl)ethanone in 96\% yield $(947 \mathrm{mg}) .{ }^{11}$ The acetophenone was then subjected to the standard procedure above to afford 1h in $63 \%$ yield $(600 \mathrm{mg})$ as a white solid. Mp 66-69 ${ }^{\circ} \mathrm{C} ;{ }^{1} \mathrm{H} \mathrm{NMR}\left(400 \mathrm{MHz}, \mathrm{CDCl}_{3}\right) \delta 8.33(\mathrm{~d}$, $J=8.4 \mathrm{~Hz}, 1 \mathrm{H}), 7.91(\mathrm{~d}, J=6 \mathrm{~Hz}, 1 \mathrm{H}), 7.75(\mathrm{~s}, 1 \mathrm{H}), 7.64(\mathrm{dd}, J=8.4,1.2 \mathrm{~Hz}, 1 \mathrm{H}), 6.40(\mathrm{~d}, J=$ $6 \mathrm{~Hz}, 1 \mathrm{H}) ;{ }^{13} \mathrm{C} \mathrm{NMR}\left(100 \mathrm{MHz}, \mathrm{CDCl}_{3}\right) \delta 176.5,156.0,155.9,135.4\left(\mathrm{q}, J_{\mathrm{CF}}=33 \mathrm{~Hz}\right), 127.3$, $127.1,123.1\left(\mathrm{q}, J_{\mathrm{CF}}=271 \mathrm{~Hz}\right), 121.6\left(\mathrm{q}, J_{\mathrm{CF}}=33 \mathrm{~Hz}\right), 116.2\left(\mathrm{q}, J_{\mathrm{CF}}=39 \mathrm{~Hz}\right), 113.6 . \mathrm{IR}: 3098$, 2980, 2889, 1654, 1631, 1436, 1348, 1311, 1169, 1122, 1089, 1018, 875, 822, $686 \mathrm{~cm}^{-1}$; HRMS (ESI): Mass calculated for $\mathrm{C}_{10} \mathrm{H}_{5} \mathrm{~F}_{3} \mathrm{NaO}_{2}{ }^{+}[\mathrm{M}+\mathrm{Na}]^{+}$237.0134, Found [M+Na] ${ }^{+} 237.0131$.<smiles>O=c1ccoc2c(Br)cccc12</smiles>

(1i) 8-bromo-4H-chromen-4-one: was synthesized from 2-bromophenol (4 mL, 35 mmol) according to the general procedure above to afford $7.35 \mathrm{~g}$ of 2-bromophenyl acetate $(98 \%$ yield $){ }^{1} \mathrm{H} \mathrm{NMR}\left(400 \mathrm{MHz}, \mathrm{CDCl}_{3}\right) \delta 7.62-7.59(\mathrm{~m}, 1 \mathrm{H}), 7.35-7.31(\mathrm{~m}$, $1 \mathrm{H}), 7.14-7.10(\mathrm{~m}, 2 \mathrm{H}), 2.35$ (s, 3H); 2-bromophenyl acetate, crude from part 1 (3 g, $13.95 \mathrm{mmol})$, was then reacted with aluminum trichloride according to the general procedure to afford 1-(3-bromo-2-hydroxyphenyl)ethanone in $20 \%$ yield $(0.610 \mathrm{~g})$ as a crude mixture. $610 \mathrm{mg}(2.83 \mathrm{mmol})$ of crude 1-(3-bromo-2-hydroxyphenyl)ethanone was then subjected to the general chromenone formation procedure to afford $240 \mathrm{mg}$ of 8 -bromo- $4 \mathrm{H}$ chromen-4-one (38\% yield) after one recrystallization from dichloromethane/hexanes. ${ }^{1} \mathrm{H}$ NMR $\left(400 \mathrm{MHz}, \mathrm{CDCl}_{3}\right) \delta 8.16(\mathrm{dd}, J=8,1.6 \mathrm{~Hz}, 1 \mathrm{H}), 7.94(\mathrm{~d}, J=6 \mathrm{~Hz}, 1 \mathrm{H}), 7.91$ (dd, $J=8,1.6 \mathrm{~Hz}$, $1 \mathrm{H}), 7.29(\mathrm{t}, J=8 \mathrm{~Hz}, 1 \mathrm{H}), 6.39(\mathrm{~d}, J=6 \mathrm{~Hz}, 1 \mathrm{H}) ;{ }^{13} \mathrm{C} \mathrm{NMR}\left(100 \mathrm{MHz}, \mathrm{CDCl}_{3}\right) \delta 177.7,155.1$, $154.8,135.2,134.9,125.1,124.5,117.9,112.8,20.9$. Spectral data matched previously reported data. ${ }^{8}$ 


\section{General Procedure for Addition of Silyl Ketene Acetals to Chromenones}
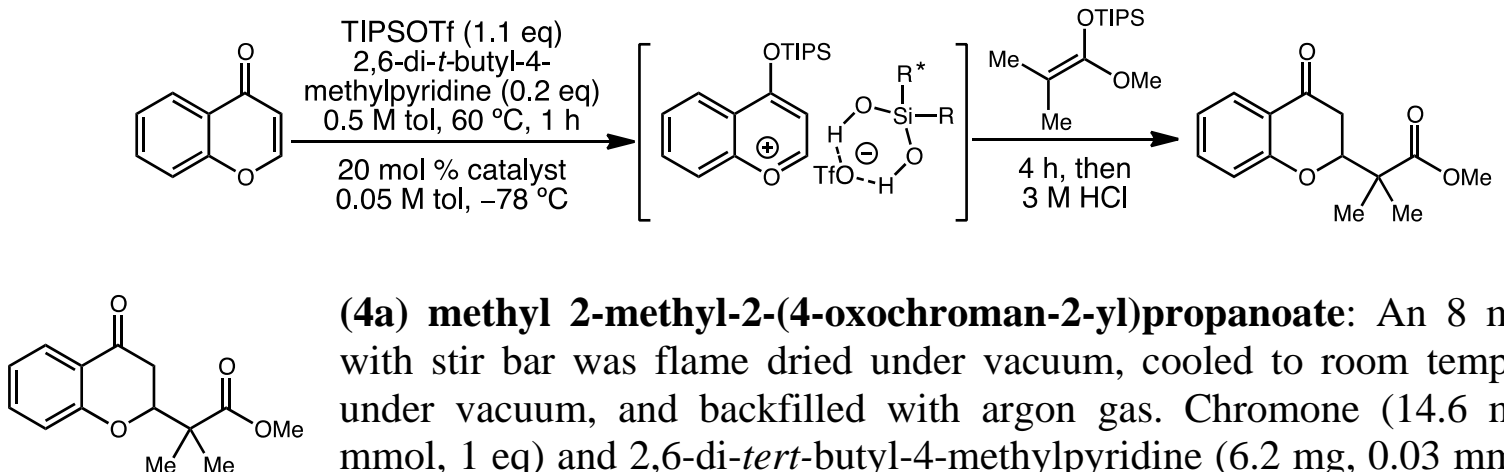

(4a) methyl 2-methyl-2-(4-oxochroman-2-yl)propanoate: An $8 \mathrm{~mL}$ vial with stir bar was flame dried under vacuum, cooled to room temperature under vacuum, and backfilled with argon gas. Chromone (14.6 mg, 0.1 mmol, 1 eq) and 2,6-di-tert-butyl-4-methylpyridine $(6.2 \mathrm{mg}, 0.03 \mathrm{mmol}, 0.3$ eq) was weighed out and placed in the vial. The vial was then placed under vacuum again and backfilled with argon. $200 \mu \mathrm{L}$ of dry toluene $(0.5 \mathrm{M})$ was added to the vial. Freshly distilled triisopropylsilyl trifluoromethanesulfonate $(29.5 \mu \mathrm{L}, 0.11 \mathrm{mmol}, 1.1 \mathrm{eq})$ was added via microliter syringe to the solution and the vial was placed in a $60{ }^{\circ} \mathrm{C}$ oil bath for one hour. After the reaction time, the vial was cooled to room temperature and further diluted with $1.3 \mathrm{~mL}$ of toluene. The vial was then cooled to $-78{ }^{\circ} \mathrm{C}$ in an acetone/dry ice bath. After an appropriate amount of time to allow the reaction to come to temperature had passed, a solution of silanediol catalyst in $0.5 \mathrm{~mL}$ toluene $(12.6 \mathrm{mg}, 0.02 \mathrm{mmol}, 0.2 \mathrm{eq}$ ) was added slowly down the side of the vial. The reaction mixture was stirred for 10 minutes before addition of the silyl ketene acetal (125 $\mu \mathrm{L}$ of a $1 \mathrm{M}$ solution in toluene, $0.125 \mathrm{mmol}, 1.25 \mathrm{eq})$ slowly down the side of the vial. After 4 hours at $-78^{\circ} \mathrm{C}$, the reaction was quenched with $200 \mu \mathrm{L}$ of $3 \mathrm{M} \mathrm{HCl}$ (aqueous) (6 eq) at $-78{ }^{\circ} \mathrm{C}$. The solution is allowed to warm to room temperature overnight. Then, the crude reaction mixture was extracted with ethyl acetate $(5 \mathrm{~mL})$, washed with water $(5 \mathrm{~mL})$, dried with $\mathrm{Na}_{2} \mathrm{SO}_{4}$, and solvent removed under vacuum. The crude mixture was then dissolved in $\mathrm{CDCl}_{3}$ and 1,3,5-trimethoxybenzene was added as an internal standard for ${ }^{1} \mathrm{H}$ NMR yields. The product was then isolated via silica gel flash column chromatography (100\% hexanes to $80 / 20$ hexanes/ethyl acetate) or preparative TLC plates for HPLC analysis (80/20 hexanes/ethyl acetate solvent system). HPLC samples are occasionally filtered through an alumnia plug to remove any undesired silanol by-products. The desired product $4 \mathbf{a}$ was $76 \%$ by ${ }^{1} \mathrm{H}$ NMR yield. ${ }^{1} \mathrm{H}$ NMR $\left(400 \mathrm{MHz}, \mathrm{CDCl}_{3}\right) \delta$ 7.88-7.86 (m, 1H), 7.48-7.44 (m, 1H), $7.01(\mathrm{t}, J=7.2 \mathrm{~Hz}, 1 \mathrm{H}), 6.95(\mathrm{~d}, J=$ $8.4 \mathrm{~Hz}, 1 \mathrm{H}), 4.64$ (dd, $J=14,2.4 \mathrm{~Hz}, 1 \mathrm{H}), 3.73(\mathrm{~s}, 3 \mathrm{H}), 2.82-2.75(\mathrm{~m}, 1 \mathrm{H}), 2.62-2.58(\mathrm{~m}, 1 \mathrm{H})$, $1.37(\mathrm{~s}, 1 \mathrm{H}), 1.28(\mathrm{~s}, 1 \mathrm{H}) ;{ }^{13} \mathrm{C} \mathrm{NMR}\left(100 \mathrm{MHz}, \mathrm{CDCl}_{3}\right) \delta 192.3,175.6,161.7,136.1,127.1$, 121.6, 120.9, 118.0, 81.8, 52.3, 46.3, 38.5, 20.9, 20.7; IR: 2981, 2889, 1729, 1687, 1607, 1463, 1392, 1303, 1221, 1133, 1115, 1078, 990, 870, $764 \mathrm{~cm}^{-1}$; HRMS (ESI): Mass calculated for $\mathrm{C}_{14} \mathrm{H}_{16} \mathrm{NaO}_{4}{ }^{+}[\mathrm{M}+\mathrm{Na}]^{+}$271.0941, Found [M+Na] ${ }^{+}$271.0934; HPLC: 30.46:69.54 e.r., Chiralpak AD-H column, 98:2 (Hexanes: isopropanol), $1 \mathrm{~mL} / \mathrm{min}, 254 \mathrm{~nm}, \mathrm{t}_{\mathrm{r}}$ (minor): $11.4 \mathrm{~min}, \mathrm{t}_{\mathrm{r}}$ (major): $13.8 \min .[\alpha]^{23}=13.0\left(\mathrm{c} 0.135, \mathrm{CHCl}_{3}\right)$.

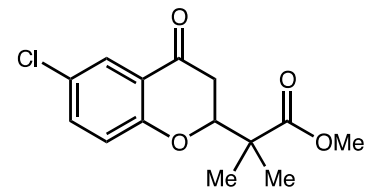

(4b) methyl 2-(6-chloro-4-oxochroman-2-yl)-2-methylpropanoate: ${ }^{1} \mathrm{H}$ NMR yield: $70 \%$; $\mathrm{Mp} 100-102{ }^{\circ} \mathrm{C} ;{ }^{1} \mathrm{H} \mathrm{NMR}\left(400 \mathrm{MHz}, \mathrm{CDCl}_{3}\right) \delta$ $7.82(\mathrm{~d}, J=2.4 \mathrm{~Hz}, 1 \mathrm{H}), 7.40(\mathrm{dd}, J=9.2,2.8 \mathrm{~Hz}, 1 \mathrm{H}), 6.92(\mathrm{~d}, J=8.8$ $\mathrm{Hz}, 1 \mathrm{H}), 4.63$ (dd, $J=14,2.4 \mathrm{~Hz}, 1 \mathrm{H}), 3.73(\mathrm{~s}, 3 \mathrm{H}), 2.81-2.73(\mathrm{~m}, 1 \mathrm{H})$, 2.64-2.59 (m, 1H), $1.36(\mathrm{~s}, 3 \mathrm{H}), 1.28(\mathrm{~s}, 3 \mathrm{H}) ;{ }^{13} \mathrm{C} \mathrm{NMR}\left(100 \mathrm{MHz}, \mathrm{CDCl}_{3}\right) \delta 191.0,175.3$, 159.9, 135.8, 127.1, 126.3, 121.6, 119.6, 82.0, 52.3, 46.1, 38.1, 20.8, 20.6; IR: 3068, 2981, 2913, 
1717, 1684, 1599, 1470, 1423, 1270, 1157, 1140, 1082, 994, 829, 770, $535 \mathrm{~cm}^{-1}$; HRMS (ESI): Mass calculated for $\mathrm{C}_{14} \mathrm{H}_{15} \mathrm{ClNaO}_{4}{ }^{+}[\mathrm{M}+\mathrm{Na}]^{+}$305.0551, Found $[\mathrm{M}+\mathrm{Na}]^{+}$305.0544; HPLC: 29.71:70.29 e.r., Chiralpak AD-H column, 98:2 (Hexanes: isopropanol), $1 \mathrm{~mL} / \mathrm{min}, 254 \mathrm{~nm}, \mathrm{t}_{\mathrm{r}}$ (minor): 9.0 min, $\mathrm{t}_{\mathrm{r}}$ (major): $11.9 \mathrm{~min} .[\alpha]_{\mathrm{D}}^{23}=17.1\left(\mathrm{c} 0.175, \mathrm{CHCl}_{3}\right)$.

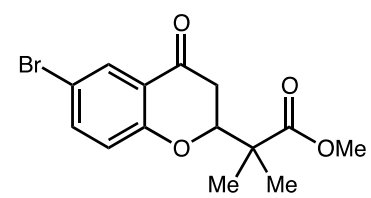

(4c) methyl 2-(6-bromo-4-oxochroman-2-yl)-2-methylpropanoate: ${ }^{1} \mathrm{H}$ NMR yield under standard conditions with $0.1 \mathrm{mmol}$ scale: $73 \%$; This reaction was also run on a $0.3 \mathrm{mmol}$ scale to confirm that the ${ }^{1} \mathrm{H} \mathrm{NMR}$ yields obtained were accurate: ${ }^{1} \mathrm{H}$ NMR yield: $86 \%$; Isolated yield of a white solid after silica gel flash column chromatography (100\% hexanes to 20/80 ethyl acetate/hexanes): 80\%; Mp 115-116 ${ }^{\circ} \mathrm{C} ;{ }^{1} \mathrm{H} \mathrm{NMR}\left(400 \mathrm{MHz}, \mathrm{CDCl}_{3}\right) \delta 7.97(\mathrm{~d}, J=2.4 \mathrm{~Hz}, 1 \mathrm{H})$, 7.49 (dd, $J=8.8,2.4 \mathrm{~Hz}, 1 \mathrm{H}), 6.87(\mathrm{~d}, J=8.8 \mathrm{~Hz}, 1 \mathrm{H}), 4.62(\mathrm{dd}, J=14,4.4 \mathrm{~Hz}, 1 \mathrm{H}), 3.73(\mathrm{~s}$, $3 \mathrm{H}), 2.81-2.73(\mathrm{~m}, 1 \mathrm{H}), 2.64-2.59(\mathrm{~m}, 1 \mathrm{H}), 1.36(\mathrm{~s}, 3 \mathrm{H}), 1.28(\mathrm{~s}, 3 \mathrm{H}) ;{ }^{13} \mathrm{C}$ NMR $(100 \mathrm{MHz}$, $\left.\mathrm{CDCl}_{3}\right) \delta 191.1,175.4,160.5,138.7,129.5,122.2,120.1,114.3,82.1,52.4,46.2,38.2,20.9$, 20.7; IR: 3069, 2981, 2914, 2889, 1717, 1684, 1599, 1471, 1435, 1423, 1388, 1271, 1220, 1191, 1158, 1140, 1083, 994, 829, 770, $686 \mathrm{~cm}^{-1}$; HRMS (ESI): Mass calculated for $\mathrm{C}_{14} \mathrm{H}_{15} \mathrm{BrNaO}_{4}{ }^{+}$ $[\mathrm{M}+\mathrm{Na}]^{+}$349.0046, Found $[\mathrm{M}+\mathrm{Na}]^{+}$349.0032 HPLC: $27.57: 72.43$ e.r., Chiralpak AD-H column, 98:2 (Hexanes: isopropanol), $1 \mathrm{~mL} / \mathrm{min}, 220 \mathrm{~nm}, \mathrm{t}_{\mathrm{r}}$ (minor): $9.1 \mathrm{~min}, \mathrm{t}_{\mathrm{r}}$ (major): $12.4 \mathrm{~min} .[\alpha]^{23} \mathrm{D}$ $=24.7\left(\mathrm{c} 0.290, \mathrm{CHCl}_{3}\right)$. After recrystallization with isopropanol:hexanes: $33 \%$ isolated yield with 74\% ee HPLC: 13.04:86.96 e.r., Chiralpak AD-H column, 98:2 (Hexanes: isopropanol), 1 $\mathrm{mL} / \mathrm{min}, 220 \mathrm{~nm}, \mathrm{t}_{\mathrm{r}}$ (minor): $9.7 \mathrm{~min}, \mathrm{t}_{\mathrm{r}}$ (major): $13.2 \mathrm{~min} .[\alpha]_{\mathrm{D}}^{23}=56.1\left(\mathrm{c} 0.19, \mathrm{CHCl}_{3}\right)$.

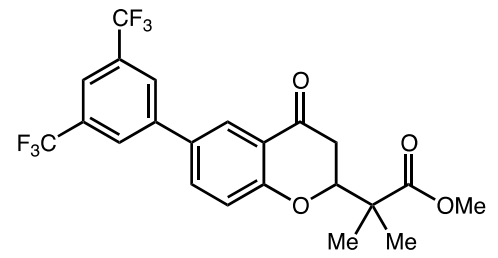

(4d) methyl 2-(6-(3,5-bis(trifluoromethyl)phenyl)-4oxochroman-2-yl)-2-methylpropanoate: ${ }^{1} \mathrm{H}$ NMR yield starting material: 67\%; ${ }^{1} \mathrm{H}$ NMR yield product: $12 \%$; Mp 127-130 ${ }^{\circ} \mathrm{C} ;{ }^{1} \mathrm{H}$ NMR $\left(400 \mathrm{MHz}, \mathrm{CDCl}_{3}\right) \delta 8.13(\mathrm{~d}, J=2.4 \mathrm{~Hz}, 1 \mathrm{H}), 7.98(\mathrm{~s}, 2 \mathrm{H})$, $7.84(\mathrm{~s}, 1 \mathrm{H}), 7.74(\mathrm{dd}, J=8.4,2.4,1 \mathrm{H}), 7.13(\mathrm{~d}, J=8.8,1 \mathrm{H}), 4.72$ $(\mathrm{dd}, J=14.4,2.8,1 \mathrm{H}), 3.76(\mathrm{~s}, 3 \mathrm{H}), 2.89-2.82(\mathrm{~m}, 1 \mathrm{H}), 2.72-2.67$ $(\mathrm{m}, 1 \mathrm{H}), 1.41(\mathrm{~s}, 3 \mathrm{H}), 1.32(\mathrm{~s}, 3 \mathrm{H}) ;{ }^{13} \mathrm{C} \mathrm{NMR}\left(150 \mathrm{MHz}, \mathrm{CDCl}_{3}\right) \delta 191.9,175.4,162.0,141.8$, $134.5,132.4\left(\mathrm{q}, J_{\mathrm{CF}}=33 \mathrm{~Hz}\right), 131.7,126.8,126.8,125.6,123.4\left(\mathrm{q}, J_{\mathrm{CF}}=271 \mathrm{~Hz}\right), 121.2,121.1$, $\left(\mathrm{p}, J_{\mathrm{CF}}=4 \mathrm{~Hz}\right), 119.3,82.2,52.4,46.3,38.4,20.9,20.8$; IR: 2981, 2889, 1719, 1691, 1612, 1504, 1464, 1380, 1332, 1272, 1185, 1171, 1125, 1081, 1057, 893, 837, $680 \mathrm{~cm}^{-1}$; HRMS (ESI): Mass calculated for $\mathrm{C}_{22} \mathrm{H}_{18} \mathrm{~F}_{6} \mathrm{NaO}_{4}{ }^{+}[\mathrm{M}+\mathrm{Na}]^{+}$483.1001, Found $[\mathrm{M}+\mathrm{Na}]^{+}$483.0992; HPLC: 21.96:78.04 e.r., Chiralpak AD-H column, 98:2 (Hexanes: isopropanol), $1 \mathrm{~mL} / \mathrm{min}, 220 \mathrm{~nm}, \mathrm{t}_{\mathrm{r}}$ (minor): $7.1 \mathrm{~min}, \mathrm{t}_{\mathrm{r}}$ (major): $10.4 \mathrm{~min} .[\alpha]^{23} \mathrm{D}=30.4\left(\mathrm{c} 0.080, \mathrm{CHCl}_{3}\right)$.

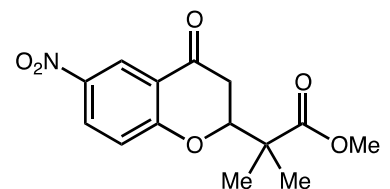

(4e) methyl 2-methyl-2-(6-nitro-4-oxochroman-2-yl)propanoate: ${ }^{1} \mathrm{H}$ NMR yield starting material: 50\%; ${ }^{1} \mathrm{H}$ NMR yield product: $27 \%$; Mp 96$103{ }^{\circ} \mathrm{C} ;{ }^{1} \mathrm{H}$ NMR $\left(400 \mathrm{MHz}, \mathrm{CDCl}_{3}\right) \delta 8.76(\mathrm{~d}, J=2.8 \mathrm{~Hz}, 1 \mathrm{H}), 8.32$ $(\mathrm{dd}, J=9.2,2.8 \mathrm{~Hz}, 1 \mathrm{H}) 7.10(\mathrm{~d}, J=8.8 \mathrm{~Hz}, 1 \mathrm{H}), 4.76(\mathrm{dd}, J=14,2.8$ $\mathrm{Hz}, 1 \mathrm{H}), 3.75(\mathrm{~s}, 3 \mathrm{H}), 2.88-2.71(\mathrm{~m}, 2 \mathrm{H}), 1.40(\mathrm{~s}, 3 \mathrm{H}), 1.31(\mathrm{~s}, 1 \mathrm{H}) ;{ }^{13} \mathrm{C} \mathrm{NMR}(100 \mathrm{MHz}$, $\left.\mathrm{CDCl}_{3}\right) \delta 189.9,174.9,165.2,142.2,130.3,123.5,120.3,119.2,82.6,52.4,46.0,37.9,20.8$, 20.6; IR: 2981, 2914, 2889, 1717, 1685, 1600, 1574, 1472, 1436, 1424, 1388, 1370, 1271, 1191, 1140, 1083, 994, 830, $770 \mathrm{~cm}^{-1}$; HRMS (ESI): Mass calculated for $\mathrm{C}_{14} \mathrm{H}_{15} \mathrm{NNaO}_{6}{ }^{+}[\mathrm{M}+\mathrm{Na}]^{+}$ 316.0792, Found $[\mathrm{M}+\mathrm{Na}]^{+}$316.0792; HPLC: 25.88:74.12 e.r., Chiralpak AD-H column, 98:2 (Hexanes: isopropanol), $1 \mathrm{~mL} / \mathrm{min}, 220 \mathrm{~nm}, \mathrm{t}_{\mathrm{r}}$ (minor): $25.5 \mathrm{~min}, \mathrm{t}_{\mathrm{r}}$ (major): $32.2 \mathrm{~min} .[\alpha]_{\mathrm{D}}^{23}=$ 
-23.1 (c $\left.0.295, \mathrm{CHCl}_{3}\right)$.

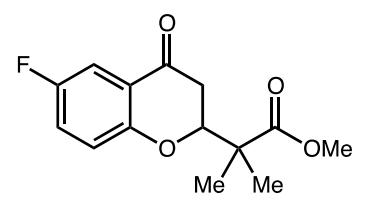

(4f) methyl 2-(6-fluoro-4-oxochroman-2-yl)-2-methylpropanoate:

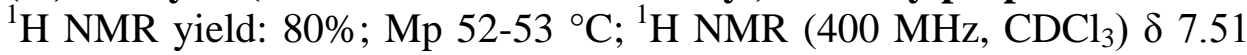
(ddd, $J=8.2,3.2,1.2 \mathrm{~Hz}, 1 \mathrm{H}), 7.19(\mathrm{td}, J=8.8,3.2 \mathrm{~Hz}, 1 \mathrm{H}), 6.94(\mathrm{dd}, J=$ 9.2, $4.4 \mathrm{~Hz}, 1 \mathrm{H}), 4.62(\mathrm{dd}, J=14,2.4), 3.73(\mathrm{~s}, 3 \mathrm{H}), 2.81-2.73(\mathrm{~m}, 1 \mathrm{H})$, 2.64-2.59 (m, 1H), $1.37(\mathrm{~s}, 3 \mathrm{H}), 1.28(\mathrm{~s}, 3 \mathrm{H}) ;{ }^{13} \mathrm{C}$ NMR $(100 \mathrm{MHz}$, $\left.\mathrm{CDCl}_{3}\right) \delta 191.6\left(\mathrm{~d}, J_{\mathrm{CF}}=1 \mathrm{~Hz}\right), 175.5,157.9\left(\mathrm{~d}, J_{\mathrm{CF}}=2 \mathrm{~Hz}\right), 157.4\left(\mathrm{~d}, J_{\mathrm{CF}}=241 \mathrm{~Hz}\right), 123.6(\mathrm{~d}$, $\left.J_{\mathrm{CF}}=2 \mathrm{~Hz}\right), 121.3(\mathrm{~d}, 7 \mathrm{~Hz}), 119.6(\mathrm{~d}, 7 \mathrm{~Hz}), 112.0\left(J_{\mathrm{CF}}=23 \mathrm{~Hz}\right), 82.1,52.4,46.2,38.2,20.9$, 20.7; IR: 2982, 2951, 1723, 1690, 1618, 1481, 1435, 1269, 1194, 1133, 995, 830, 710, $545 \mathrm{~cm}^{-1}$; HRMS (ESI): Mass calculated for $\mathrm{C}_{14} \mathrm{H}_{15} \mathrm{FNaO}_{4}{ }^{+}[\mathrm{M}+\mathrm{Na}]^{+}$289.0847, Found [M+Na] $]^{+} 289.0844$; HPLC: 30.54-69.46 e.r., (Hexanes: isopropanol), $1 \mathrm{~mL} / \mathrm{min}, 220 \mathrm{~nm}, \mathrm{t}_{\mathrm{r}}$ (minor): $13.3 \mathrm{~min}, \mathrm{t}_{\mathrm{r}}$ (major): $19.4 \min .[\alpha]^{23}=13.6\left(\mathrm{c} 0.33, \mathrm{CHCl}_{3}\right)$.

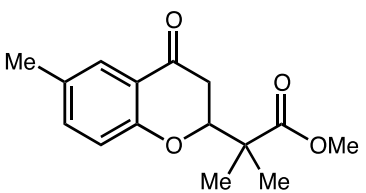

(4g) methyl 2-methyl-2-(6-methyl-4-oxochroman-2-yl)propanoate: ${ }^{1} \mathrm{H}$ NMR yield: $53 \%$; $\mathrm{Mp} 79-82{ }^{\circ} \mathrm{C} ;{ }^{1} \mathrm{H}$ NMR $\left(400 \mathrm{MHz}, \mathrm{CDCl}_{3}\right) \delta$ 7.66$7.75(\mathrm{~m}, 1 \mathrm{H}), 7.28-7.26(\mathrm{~m}, 1 \mathrm{H}), 6.86(\mathrm{~d}, J=8.4 \mathrm{~Hz}, 1 \mathrm{H}), 4.60(\mathrm{dd}, J=$ $14,2.4 \mathrm{~Hz}, 1 \mathrm{H}), 3.72(\mathrm{~s}, 3 \mathrm{H}), 2.80-2.75(\mathrm{~m}, 1 \mathrm{H}), 2.59-2.55(\mathrm{~m}, 1 \mathrm{H}), 2.29$ $(\mathrm{s}, 3 \mathrm{H}), 1.36(\mathrm{~s}, 3 \mathrm{H}), 1.27(\mathrm{~s}, 3 \mathrm{H}) ;{ }^{13} \mathrm{C} \mathrm{NMR}\left(100 \mathrm{MHz}, \mathrm{CDCl}_{3}\right) \delta$ 192.6, 175.7, 159.8, 137.2, 131.0, 126.6, 120.5, 117.8, 81.8, 52.3, 46.3, 38.5, 20.9, 20.8, 20.5; IR: 2921, 2927, 1730, 1685, 1614, 1488, 1468, 1393, 1291, 1253, 1134, 1075, 992, 830, 583, $541 \mathrm{~cm}^{-1}$; HRMS (ESI): Mass calculated for $\mathrm{C}_{15} \mathrm{H}_{18} \mathrm{NaO}_{4}{ }^{+}[\mathrm{M}+\mathrm{Na}]^{+}$285.1097, Found [M+Na] ${ }^{+}$285.1096; HPLC: 42.15:57.85 e.r., Chiralpak AD-H column, 98:2 (Hexanes: isopropanol), $1 \mathrm{~mL} / \mathrm{min}, 254 \mathrm{~nm}, \mathrm{t}_{\mathrm{r}}$ (minor): 10.3 $\min , \mathrm{t}_{\mathrm{r}}$ (major): $14.8 \mathrm{~min} .[\alpha]_{\mathrm{D}}^{23}=2.9\left(\mathrm{c} 0.335, \mathrm{CHCl}_{3}\right)$.

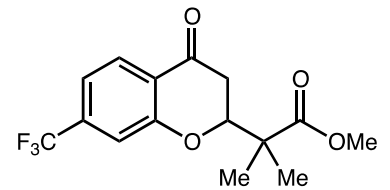

(4h) methyl 2-methyl-2-(4-oxo-7-(trifluoromethyl)chroman-2yl)propanoate: ${ }^{1} \mathrm{H}$ NMR yield: $90 \%$; $\mathrm{Mp} 61-64{ }^{\circ} \mathrm{C}$; ${ }^{1} \mathrm{H}$ NMR (400 $\left.\mathrm{MHz}, \mathrm{CDCl}_{3}\right) \delta$ 7.99-7.97 (m, 1H), 7.26-7.24 (m, 2H), $4.700(\mathrm{dd}, J=14$, $2.4 \mathrm{~Hz}, 1 \mathrm{H}), 3.75(\mathrm{~s}, 3 \mathrm{H}), 2.87-2.79(\mathrm{~m}, 1 \mathrm{H}), 2.70-2.65(\mathrm{~m}, 1 \mathrm{H}), 1.39(\mathrm{~s}$, $3 \mathrm{H}), 1.30(\mathrm{~s}, 3 \mathrm{H}) ;{ }^{13} \mathrm{C} \mathrm{NMR}\left(150 \mathrm{MHz}, \mathrm{CDCl}_{3}\right) \delta 191.4,175.3,161.4,137.3\left(\mathrm{q}, J_{\mathrm{CF}}=33\right), 128.1$, $123.2\left(\mathrm{q}, J_{\mathrm{CF}}=272 \mathrm{~Hz}\right), 123.0,118.0\left(\mathrm{q}, J_{\mathrm{CF}}=5 \mathrm{~Hz}\right), 115.7\left(\mathrm{q}, J_{\mathrm{CF}}=5 \mathrm{~Hz}\right), 82.3,52.5,46.2$, 38.4, 20.9, 20.8; IR: 2981, 2889, 1730, 1699, 1625, 1437, 1332, 1208, 1165, 1123, 1072, 994, 882, 830, $723 \mathrm{~cm}^{-1}$; HRMS (ESI): Mass calculated for $\mathrm{C}_{15} \mathrm{H}_{15} \mathrm{~F}_{3} \mathrm{NaO}_{4}^{+}[\mathrm{M}+\mathrm{Na}]^{+} 339.0815$, Found $[\mathrm{M}+\mathrm{Na}]^{+}$339.0817; HPLC: 34.18-65.82 e.r., Chiralcel OJ column, 99:1 (Hexanes: isopropanol), $1 \mathrm{~mL} / \mathrm{min}, 220 \mathrm{~nm}, \mathrm{t}_{\mathrm{r}}$ (minor): $10.0 \mathrm{~min}, \mathrm{t}_{\mathrm{r}}$ (major): $13.9 \mathrm{~min}$. $[\alpha]^{23}{ }_{\mathrm{D}}=9.5$ (c 0.155 , $\left.\mathrm{CHCl}_{3}\right)$.

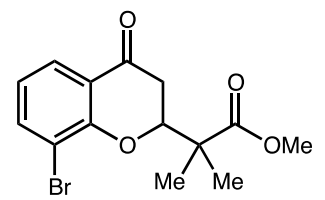

(4i) methyl 2-(8-bromo-4-oxochroman-2-yl)-2-methylpropanoate: ${ }^{1} \mathrm{H}$ NMR yield: $62 \%$; ${ }^{1} \mathrm{H}$ NMR $\left(400 \mathrm{MHz}, \mathrm{CDCl}_{3}\right) \delta 7.82(\mathrm{dd}, J=7.6,1.6 \mathrm{~Hz}$, $1 \mathrm{H}), 7.70(\mathrm{dd}, J=7.6,1.6 \mathrm{~Hz}, 1 \mathrm{H}), 6.90(\mathrm{t}, J=7.6 \mathrm{~Hz}, 1 \mathrm{H}), 4.70(\mathrm{dd}, J=14$, $2.4 \mathrm{~Hz}, 1 \mathrm{H}), 3.75(\mathrm{~s}, 3 \mathrm{H}), 2.85-2.77(\mathrm{~m}, 1 \mathrm{H}), 2.67-2.62(\mathrm{~m}, 1 \mathrm{H}), 1.43(\mathrm{~s}$, $3 \mathrm{H}), 1.32(\mathrm{~s}, 3 \mathrm{H}) ;{ }^{13} \mathrm{C} \mathrm{NMR}\left(150 \mathrm{MHz}, \mathrm{CDCl}_{3}\right) \delta 191.5,175.4,158.0,139.2$, 126.4, 122.3, 122.1, 112.0, 82.7, 52.5, 46.4, 38.2, 21.0, 20.6; IR: 2980, 2889, 1727, 1693, 1593, 1462, 1429, 1391, 1289, 1240, 1133, 1062, 991, $733 \mathrm{~cm}^{-1}$; HRMS (ESI): Mass calculated for $\mathrm{C}_{14} \mathrm{H}_{15} \mathrm{BrNaO}_{4}{ }^{+}[\mathrm{M}+\mathrm{Na}]^{+}$349.0046, Found $[\mathrm{M}+\mathrm{Na}]^{+}$349.0039; HPLC: 40.05-50.95 e.r., Chiralpak AD-H column, 99.5:0.5 (Hexanes: isopropanol), $1 \mathrm{~mL} / \mathrm{min}, 220 \mathrm{~nm}, \mathrm{t}_{\mathrm{r}}$ (minor): 19.3 
min, $\mathrm{t}_{\mathrm{r}}$ (major): $34.8 \mathrm{~min} .[\alpha]_{\mathrm{D}}^{23}=1.6\left(\mathrm{c} 0.17, \mathrm{CHCl}_{3}\right)$.

\section{General Procedure for the Formation of the N-sulfinyl Imine}

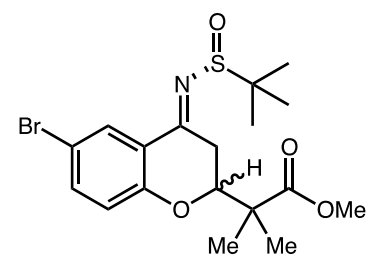

(11) methyl 2-((E)-6-bromo-4-(((R)-tert-butylsulfinyl)imino)chroman2-yl)-2-methylpropanoate: Using a modified known procedure, ${ }^{12}$ racemic ketone $(\mathbf{4 c})(100 \mathrm{mg}, 0.3 \mathrm{mmol})$ and $(R)$-2-methylpropane-2sulfinamide $(37.0 \mathrm{mg}, 0.3 \mathrm{mmol}, 1 \mathrm{eq})$ were place in a flame-dried flask with stirbar and dissolved in $5 \mathrm{~mL}$ dry THF (0.06 M). $157.7 \mathrm{mg}$ of $\mathrm{Ti}(\mathrm{OMe})_{4}(0.9 \mathrm{mmol}, 3 \mathrm{eq})$ was added to the flask and it was fitted with a reflux condenser under a nitrogen atmosphere and refluxed for 48 hours. The volume of THF was monitored and more added as necessary to maintain stirring of the solution. After the reaction time, the flask was cooled to room temperature, quenched with brine $(2 \mathrm{~mL})$ and filtered through Celite with ethyl acetate. The filtrate was diluted with water $(10 \mathrm{~mL})$ extracted with EtOAc $(10 \mathrm{~mL} \times 3)$, washed brine $(10 \mathrm{~mL})$, and dried with $\mathrm{Na}_{2} \mathrm{SO}_{4}$. The mixture of diastereomers was isolated via silica gel flash column chromatography (100\% hexanes to $30 \%$ ethyl acetate:hexanes) to yield $104.9 \mathrm{mg}$ of product as a yellow solid (80\% yield). Mp 106-110 ${ }^{\circ} \mathrm{C} ;{ }^{1} \mathrm{H}$ NMR $\left(400 \mathrm{MHz}, \mathrm{CDCl}_{3}\right) \delta 8.02(\mathrm{dd}, J=4.5,2.5 \mathrm{~Hz}, 1 \mathrm{H}), 7.44(\mathrm{dd}, J=8.5,2.4 \mathrm{~Hz}, 1 \mathrm{H})$, $6.80(\mathrm{dd}, J=8.7,1.5 \mathrm{~Hz}, 1 \mathrm{H}), 4.44-4.38(\mathrm{~m}, 1 \mathrm{H}), 4.04(\mathrm{dd}, J=16.6,2.5 \mathrm{~Hz}, 0.5 \mathrm{H}), 3.73(\mathrm{~s}, 3 \mathrm{H})$, $3.66(\mathrm{dd}, J=17,2 \mathrm{~Hz}, 0.61 \mathrm{H}), 2.82(\mathrm{dd}, J=17,14 \mathrm{~Hz}, 0.53 \mathrm{H}), 2.59$ (dd, $J=16.5,14 \mathrm{~Hz}, 0.4 \mathrm{H}$ ), $1.34-1.33(\mathrm{~m}, 12 \mathrm{H}), 1.27(\mathrm{~s}, 3 \mathrm{H}) ;{ }^{13} \mathrm{C} \mathrm{NMR}\left(100 \mathrm{MHz}, \mathrm{CDCl}_{3}\right) \delta 175.7,175.5,168.8,168.8$, $158.1,158.0,136.9,136.8,129.1,129.1,122.5,122.4,120.1,114.1,114.1,80.7,80.4,58.5$, 58.3, 52.4, 46.2, 31.0, 30.1, 22.8, 22.8, 21.3, 21.0, 20.4, 20.3; IR: 2981, 2950, 1728, 1610, 1585, 1464, 1415, 1363, 1266, 1219, 1129, 1067, 997, 822, $662 \mathrm{~cm}^{-1}$; HRMS (ESI): Mass calculated for $\mathrm{C}_{18} \mathrm{H}_{24} \mathrm{BrNNaO}_{4} \mathrm{~S}^{+}[\mathrm{M}+\mathrm{Na}]^{+}$452.0502, Found [M+Na] ${ }^{+}$452.0502; HPLC: OD-H 97:3 (Hexanes: isopropanol), $1 \mathrm{~mL} / \mathrm{min}, 220 \mathrm{~nm}, \mathrm{t}_{\mathrm{r}}$ (major): $6.66 \mathrm{~min}, \mathrm{t}_{\mathrm{r}}$ (minor): $8.22 \mathrm{~min}$.

\section{Determination of the Major Enantiomer}

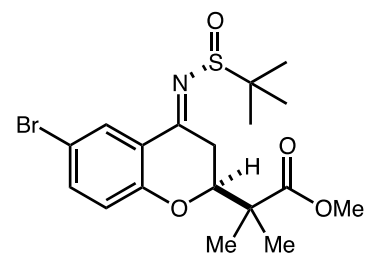

(11a)

methyl

2-((S,E)-6-bromo-4-(((R)-tertbutylsulfinyl)imino)chroman-2-yl)-2-methylpropanoate:

This

diastereomer was isolated via slow evaporation as it was not separable by column chromatography in our hands. The mixture of diastereomers (11) was dissolved in a minimal amount of DCM and layered with hexanes.

The vial was allowed to sit open to air for slow evaporation over several days. Clear, yellow squares eventually crystallized in the bottom of the vessel which contained a minimal amount of the other diastereomer. These were carefully extracted from the mixture and characterized via NMR and X-ray crystallography to determine the stereochemistry at the 2position. This isolated diastereoemer was subjected to HPLC analysis to confirm that it was indeed majority one diastereomer. The crystal plate used to determine the stereochemistry was also subjected to HPLC analysis to confirm that the isolated diastereomers were identical (this HPLC trace contains grease due to the adhesive used for obtaining the X-ray data; the exact crystal used for data collection broke in transport and could not be subjected to HPLC analysis). $\mathrm{X}$-ray analysis indicated that the crystal used for obtaining the data was only one enantiomer. $\mathrm{Mp}$ $116-122{ }^{\circ} \mathrm{C} ;{ }^{1} \mathrm{H} \mathrm{NMR}\left(400 \mathrm{MHz}, \mathrm{CDCl}_{3}\right) \delta 8.01(\mathrm{~d}, J=2.8 \mathrm{~Hz}, 1 \mathrm{H}), 7.44(\mathrm{dd}, J=8.8,2.4 \mathrm{~Hz}$, $1 \mathrm{H}), 6.80(\mathrm{~d}, J=8.8 \mathrm{~Hz}, 1 \mathrm{H}) ; 4.40(\mathrm{dd}, J=14,2 \mathrm{~Hz}, 1 \mathrm{H}) ; 3.73(\mathrm{~s}, 3 \mathrm{H}), 3.66(\mathrm{dd}, J=17.2,2.4$ $\mathrm{Hz}, 1 \mathrm{H}), 2.83(\mathrm{dd}, J=17.2,14 \mathrm{~Hz}, 1 \mathrm{H}) ; 1.34-1.33(\mathrm{~m}, 12 \mathrm{H}), 1.27(\mathrm{~s}, 3 \mathrm{H}) ;{ }^{13} \mathrm{C} \mathrm{NMR}(100 \mathrm{MHz}$, $\left.\mathrm{CDCl}_{3}\right) \delta 175.7,168.8,158.1,136.8,129.2,122.4,120.1,114.1,80.4,58.5,52.4,46.2,31.0$, 
22.8, 22.8, 21.0, 20.4; HPLC: 88.76-11.24 e.r., Chiralpak OD-H 97:3 (Hexanes: isopropanol), 1 $\mathrm{mL} / \mathrm{min}, 220 \mathrm{~nm}, \mathrm{t}_{\mathrm{r}}$ (major): $6.68 \mathrm{~min}, \mathrm{t}_{\mathrm{r}}$ (major): $8.30 \mathrm{~min}$.<smiles>COC(=O)C(C)(C)[C@H]1CC(=O)c2cc(Br)ccc2O1</smiles>

(4c)

(S)-methyl

2-(6-bromo-4-oxochroman-2-yl)-2methylpropanoate: The isolated diastereomer (11a) $(13.7 \mathrm{mg}, 0.032$ mmol) was dissolved in methanol $(1.0 \mathrm{~mL}, 0.3 \mathrm{M}) . \mathrm{HCl}$ was added slowly $(0.1 \mathrm{~mL}, 12 \mathrm{M})$ and allowed to stir at room temperature for 30 minutes. The product was neutralized with $\mathrm{NaHCO}_{3}$ (aq) extracted with dichloromethane, washed with water, and dried with $\mathrm{Na}_{2} \mathrm{SO}_{4}$ to afford pure, crude $4 \mathbf{c}$ (94\% yield, $9.8 \mathrm{mg}$ ). This product was then subjected to prep TLC for HPLC analysis to demonstrate that this was the major enantiomer obtained during the silanediol-catalyzed addition of silyl ketene acetals to the chromenone salts.

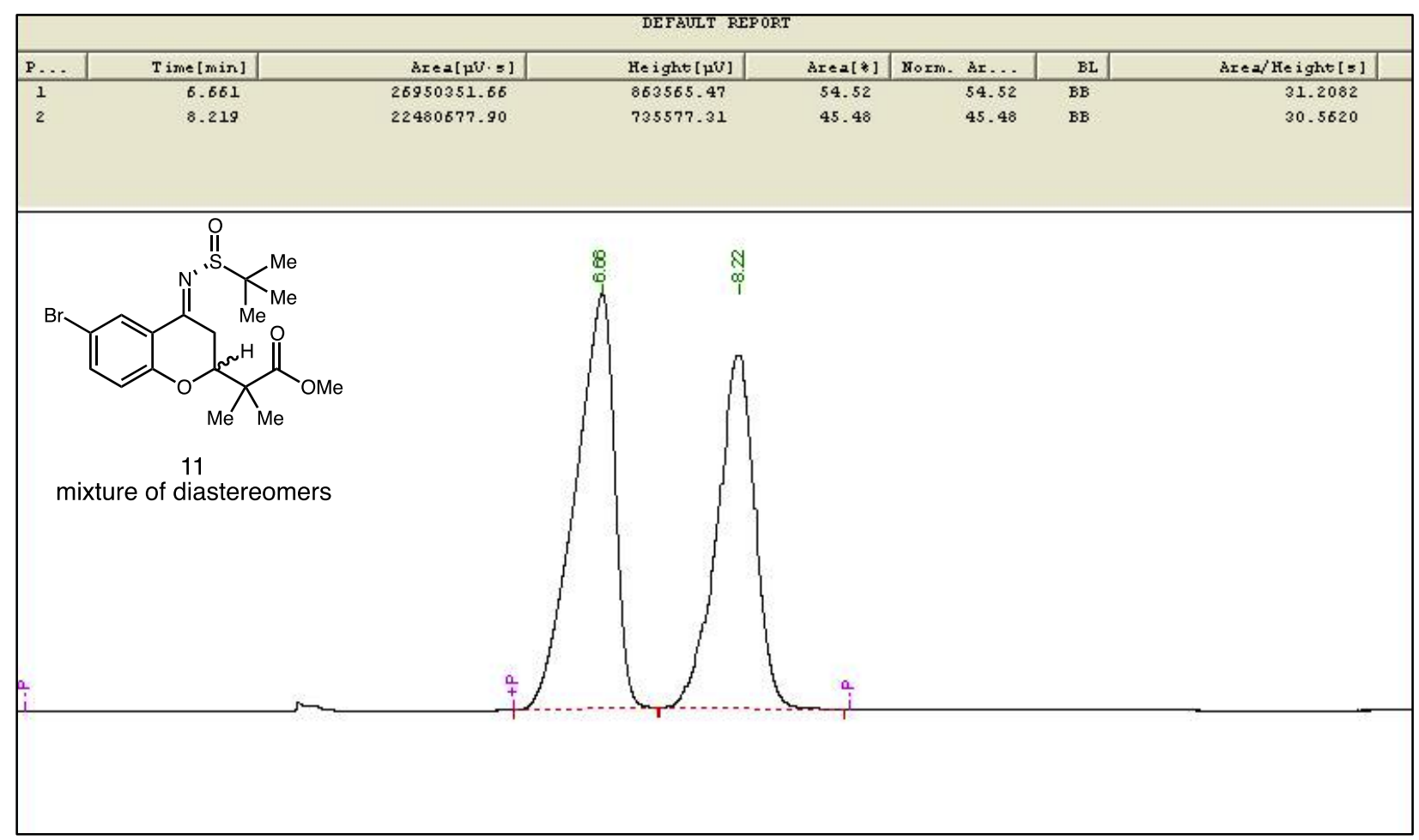



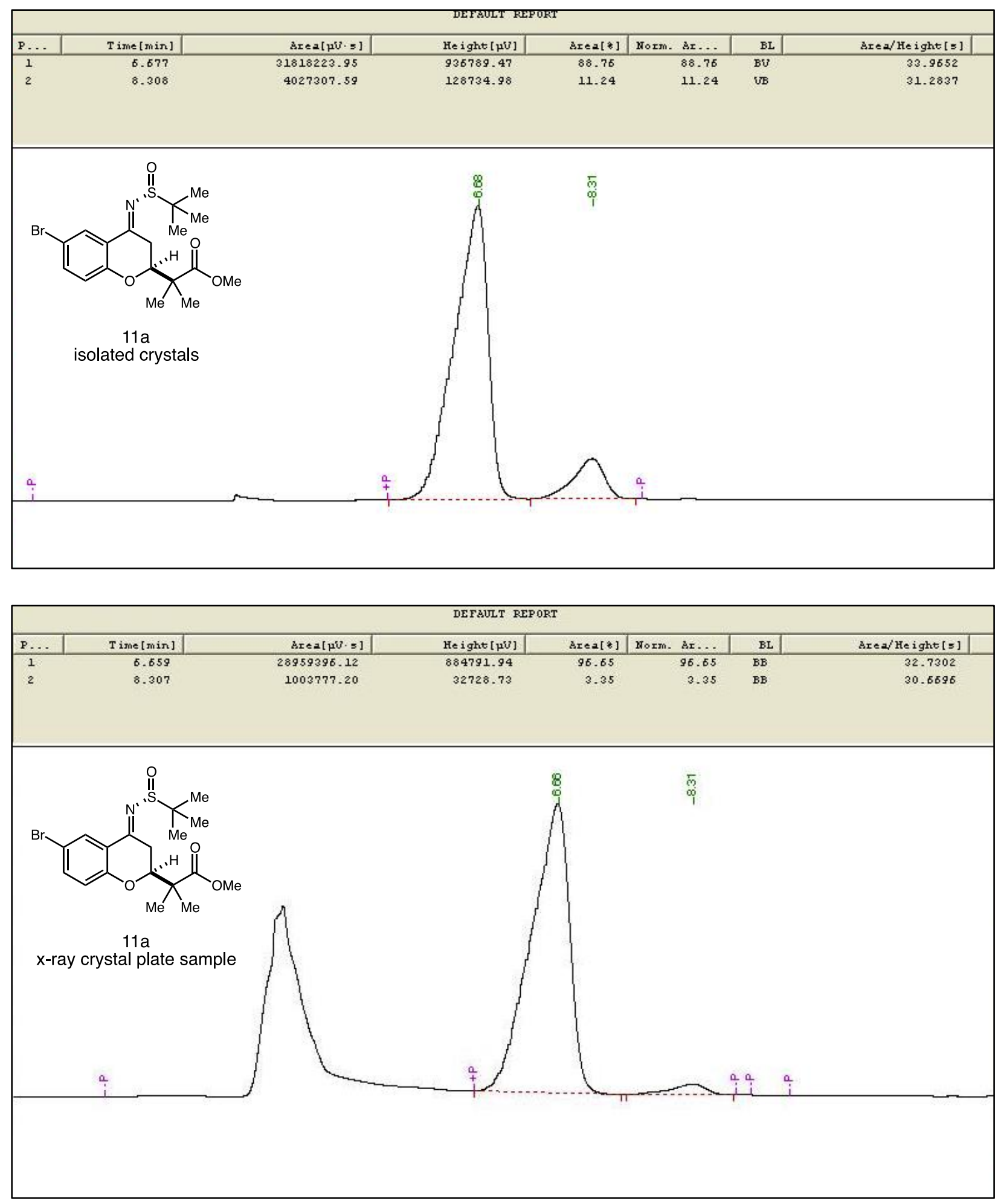


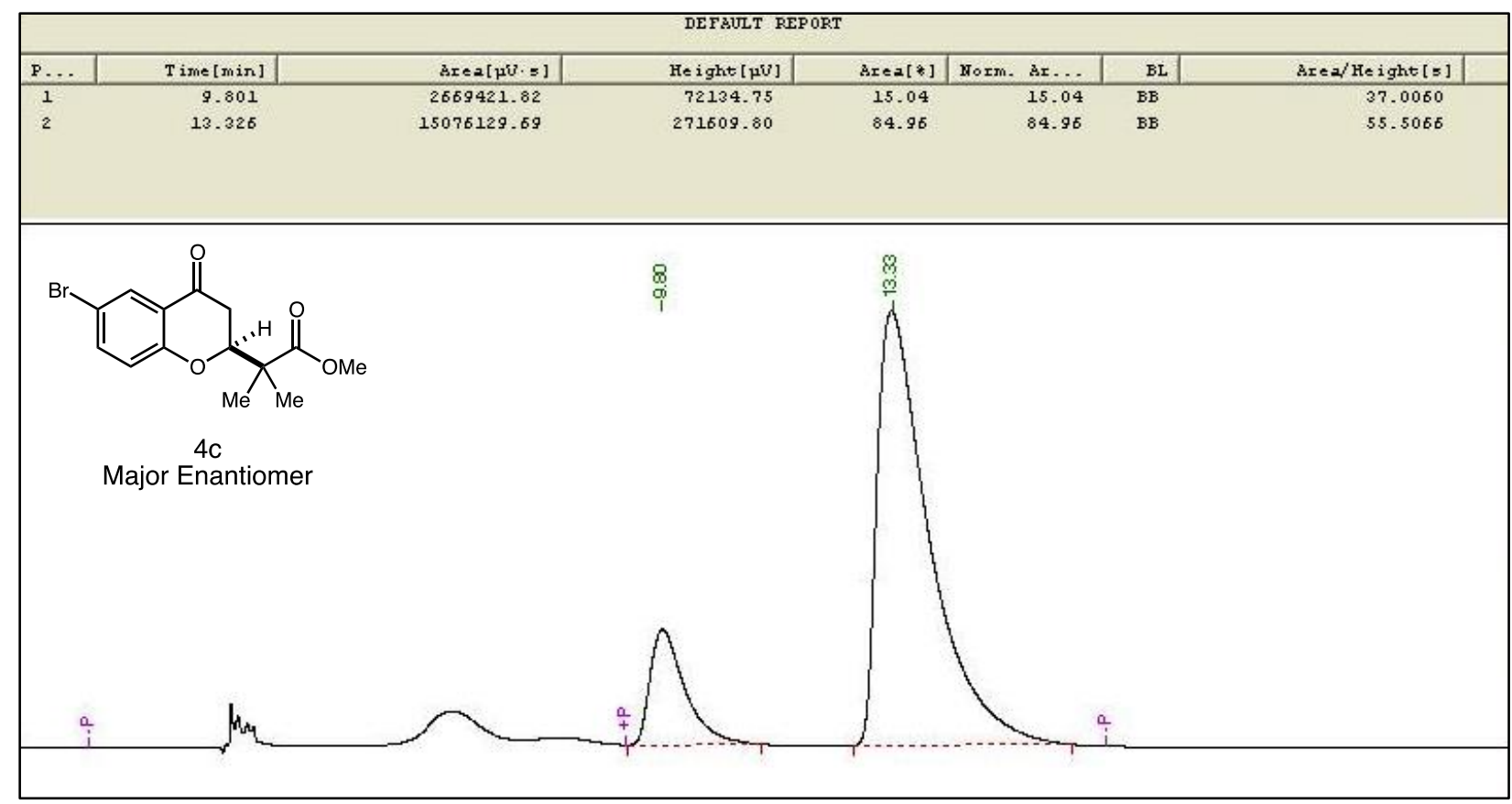

\section{Determination of Association Constant}

The association constant of silanediol 5a (host) and tetrabutylammonium triflate (TBAOTf) (guest) was determined by fluorescence titrations. ${ }^{13,14}$ Chloroform was purified to remove any stabilizers and distilled from $\mathrm{CaH}_{2}$ prior to use. Commercially available TBAOTf was dried under reduced pressure for 1-day prior to use. The titration experiments were carried out with a host solution $\left(3 \mathrm{~mL}, 5 \times 10^{-5} \mathrm{M}\right.$ in $\mathrm{CHCl}_{3}$ ) in a quartz cell and fluorescence spectra recorded upon the addition of aliquots of the stock solution of guest ion in $\mathrm{CHCl}_{3}$ with a microsyringe. Titration data in the appropriate wavelength range were analyzed with multi-wavelength curve fitting. The sum of the square deviation is defined as equation 1.

Equation 1: $\quad \chi^{2}=\sum_{\lambda} \sum_{\alpha}\left(I_{\lambda \alpha}^{\mathrm{obsd}}-I_{\lambda \alpha}^{c \text { alcd }}\right)^{2}$

Where $I_{\lambda \alpha}^{\text {obsd }}$ and $I_{\lambda \alpha}^{\text {calcd }}$ observed and calculated absorbance or fluorescence intesnsity of host in the presence of $\alpha$ equive of anions at $\lambda \mathrm{nm}$ emission $I_{\lambda \alpha}^{c \text { alcd }}$ can be calculated as equation 2 .

Equation 2: $\quad I_{\lambda \alpha}^{c \text { alcd }}=I_{\lambda 0}+\left(I_{\lambda \infty}-I_{\lambda 0}\right) \frac{(\alpha+1)[\mathrm{H}]_{\mathrm{t}}+\frac{1}{K_{11}}-\sqrt{(\alpha-1)^{2}[\mathrm{H}]_{\mathrm{t}}^{2}+\frac{2(\alpha+1)}{K_{11}}[\mathrm{H}]_{\mathrm{t}}+\frac{1}{K_{11}^{2}}}}{2[\mathrm{H}]_{\mathrm{t}}}$

In which $I_{\lambda 0}$ and $I_{\lambda_{\infty}}$ are the fluorescence intensities of host and the complex respectively; $[\mathrm{H}]_{\mathrm{t}}$ is the total concentration of host; $\mathrm{K}_{11}$ is the associate constant during the complexation. The association constant and the sets of $I_{\lambda 0}$ and $I_{\lambda \infty}$ were calculated by non-linear least-squares treatment based on the Powell algorithm to minimize $\chi^{2}$ with a self-written software on a 32-bit Windows PC. The titration experiments were duplicated independently 4 times and the mean value and the standard deviation are reported. 
Representative fluorescence spectra upon the addition of TBAOTf to silanediol $\mathbf{5 a}$ in $\mathrm{CHCl}_{3}$ :

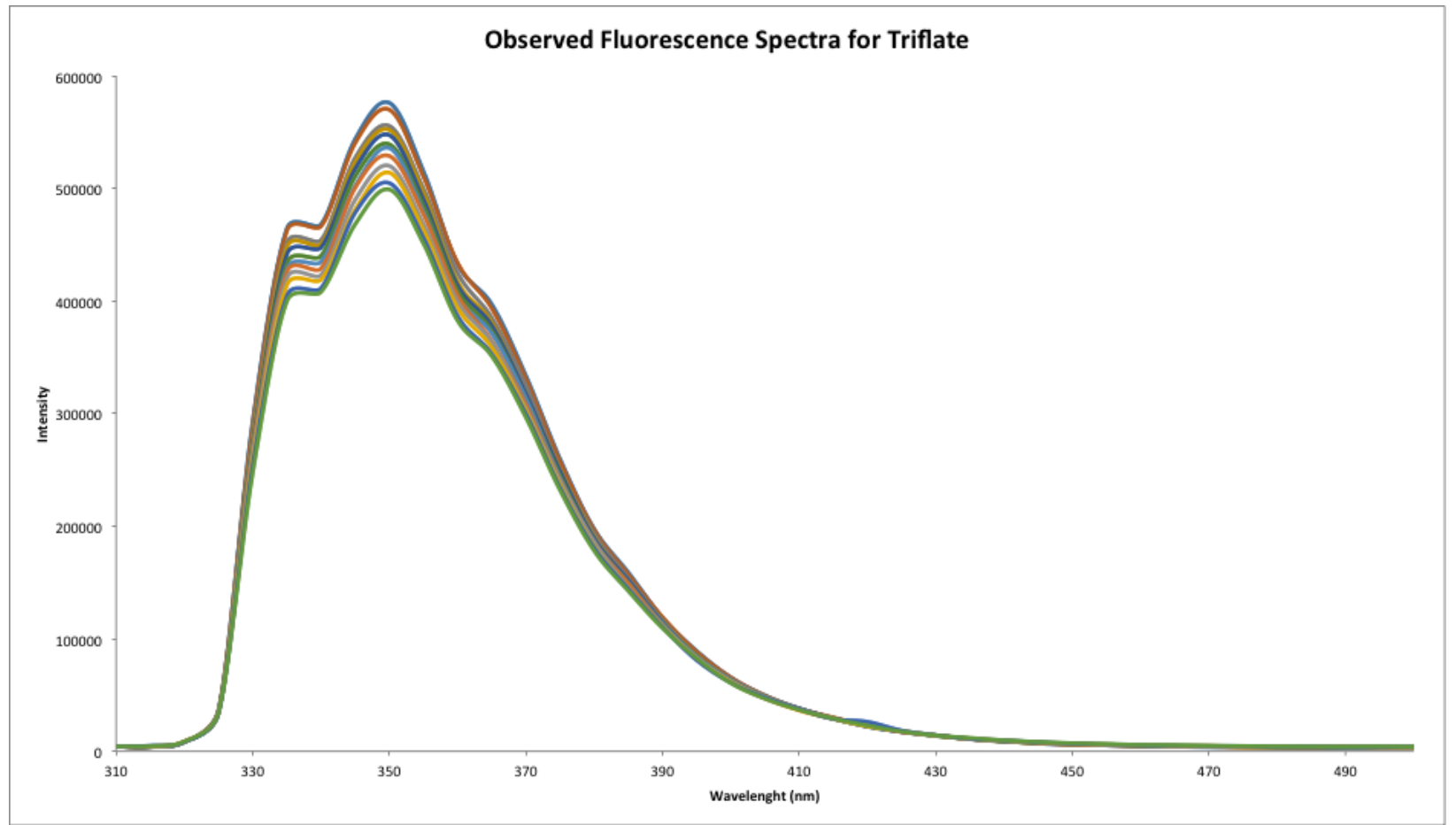

\section{References}

(1) Ding, Z.; Osminski, W. E. G.; Ren, H.; Wulff, W. D. Org. Process Res. Dev. 2011, 15 (5), 1089-1107.

(2) Ooi, T.; Kameda, M.; Maruoka, K. J. Am. Chem. Soc. 2003, 125 (17), 5139-5151.

(3) Wenzel, A. G.; Jacobsen, E. N. J. Am. Chem. Soc. 2002, 124 (44), 12964-12965.

(4) Liu, S.-Y.; Hills, I. D.; Fu, G. C. J. Am. Chem. Soc. 2005, 127 (44), 15352-15353.

(5) Schäckel, R.; Hinkelmann, B.; Sasse, F.; Kalesse, M. Angew. Chem. Int. Ed. 2010, 49 (9), 1619-1622.

(6) Pallavicini, M.; Budriesi, R.; Fumagalli, L.; Ioan, P.; Chiarini, A.; Bolchi, C.; Ugenti, M. P.; Colleoni, S.; Gobbi, M.; Valoti, E. J. Med. Chem. 2006, 49 (24), 7140-7149.

(7) Stubbing, L. A.; Li, F. F.; Furkert, D. P.; Caprio, V. E.; Brimble, M. A. Tetrahedron 2012, 68 (34), 6948-6956.

(8) Patonay, T.; Vasas, A.; Kiss-Szikszai, A.; Silva, A. M. S.; Cavaleiro, J. A. S. Aust. J. Chem. 2010, 63 (11), 1582.

(9) Diao, T.; Stahl, S. S. J. Am. Chem. Soc. 2011, 133 (37), 14566-14569.

(10) Liu, B.; Pang, Y.; Bouhenni, R.; Duah, E.; Paruchuri, S.; McDonald, L. Chem Commun 2015, 51 (55), 11060-11063.

(11) Hideharu Uchida et al. Novel Heterocyclidene Acetamide Derivative. US Patent Application 20080287428, March 7, 2008.

(12) Sirvent, J. A.; Foubelo, F.; Yus, M. Chem. Commun. 2012, 48 (19), 2543.

(13) Kondo, S.; Harada, T.; Tanaka, R.; Unno, M. Org. Lett. 2006, 8 (20), 4621-4624.

(14) Kondo, S.; Bie, Y.; Yamamura, M. Org. Lett. 2013, 15 (3), 520-523. 


\section{Select HPLC Traces}

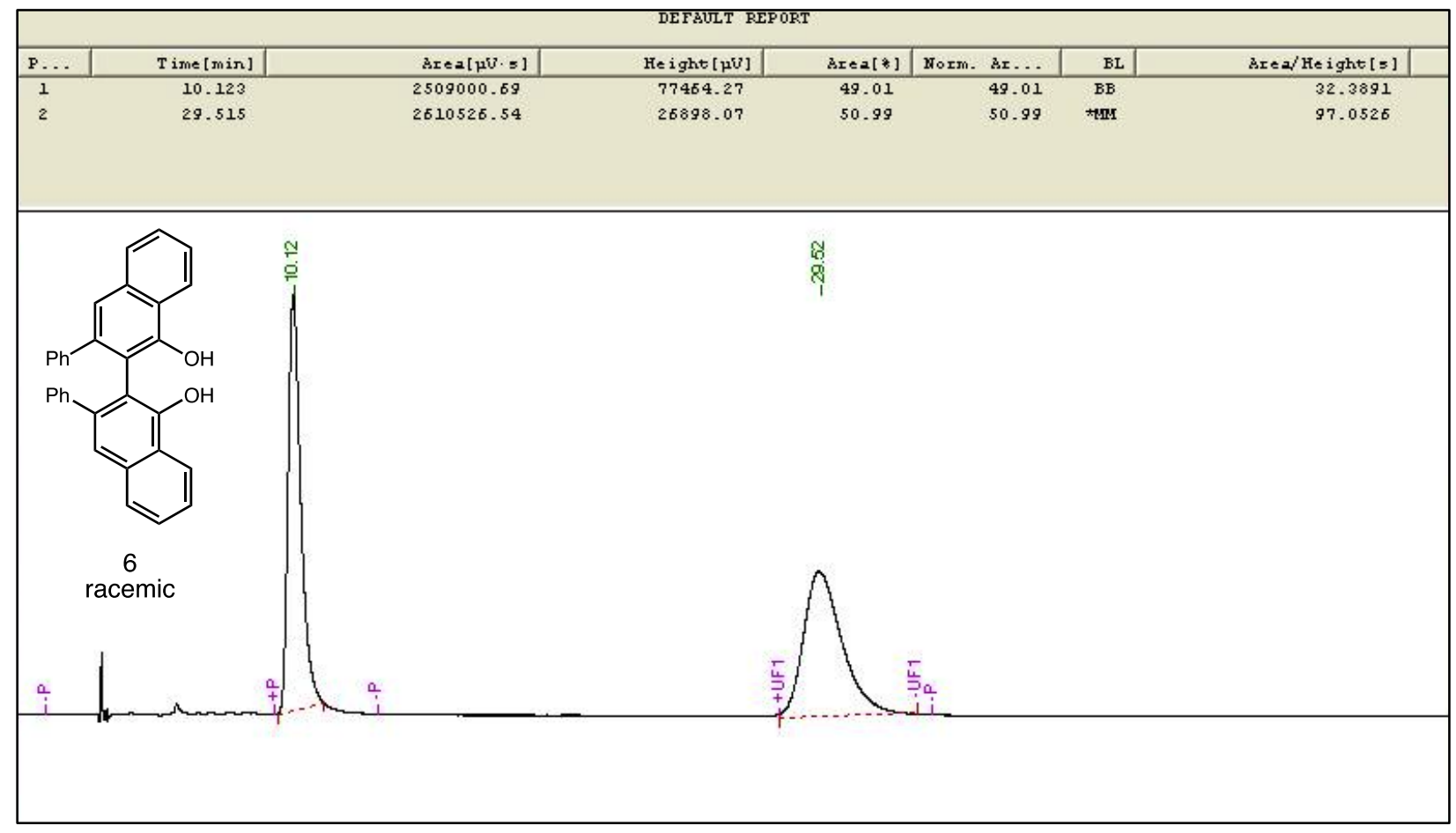

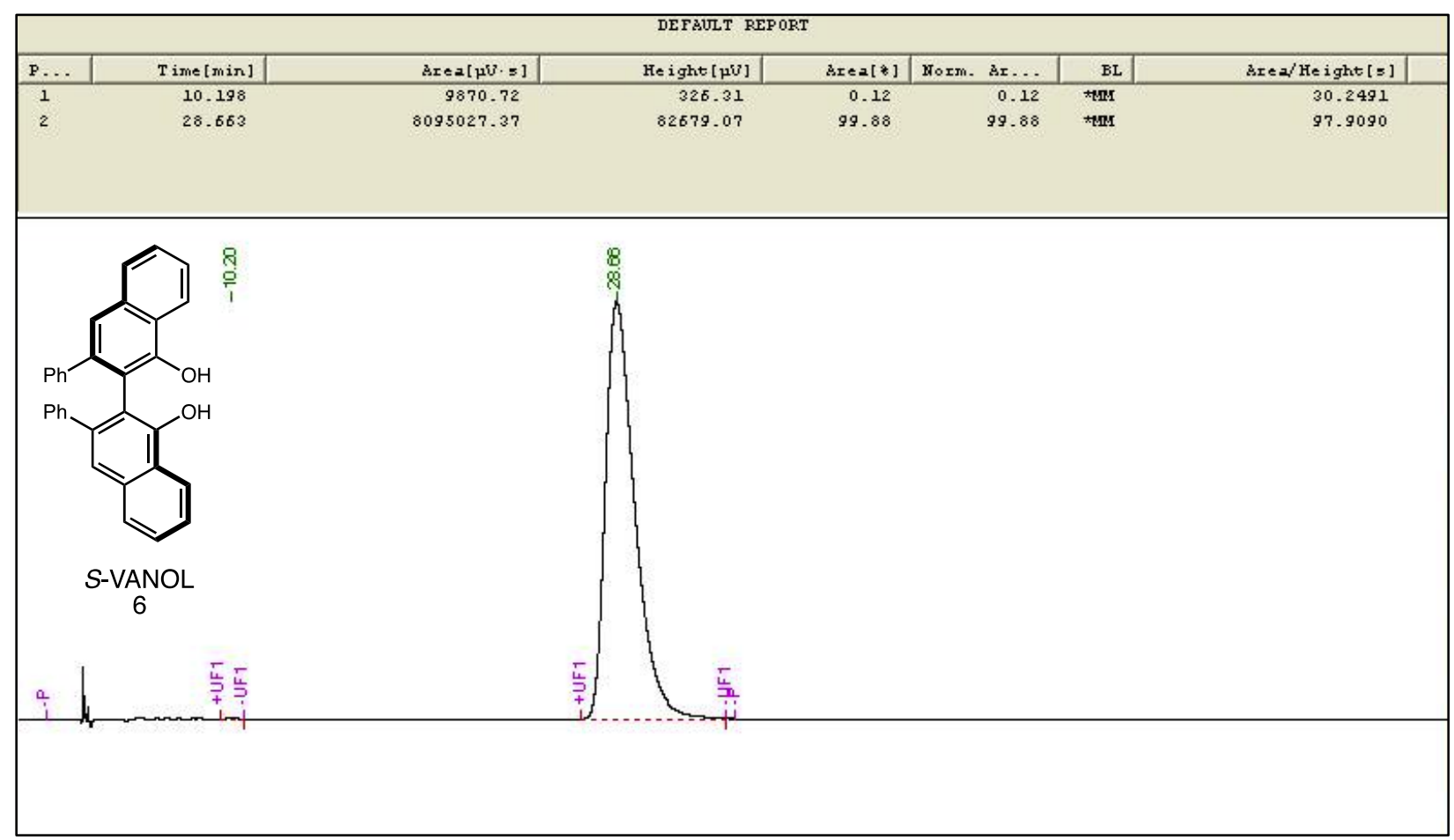




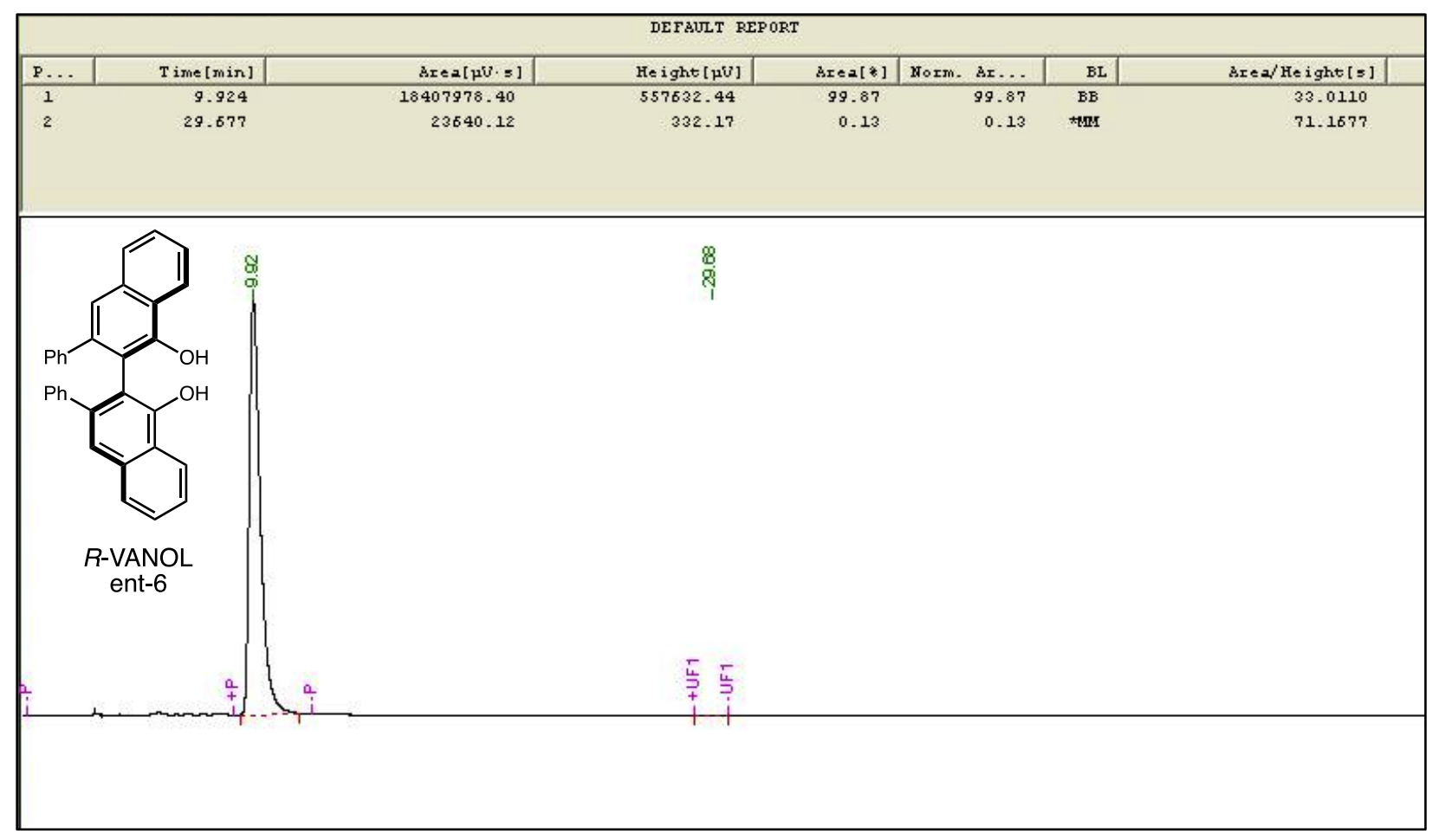



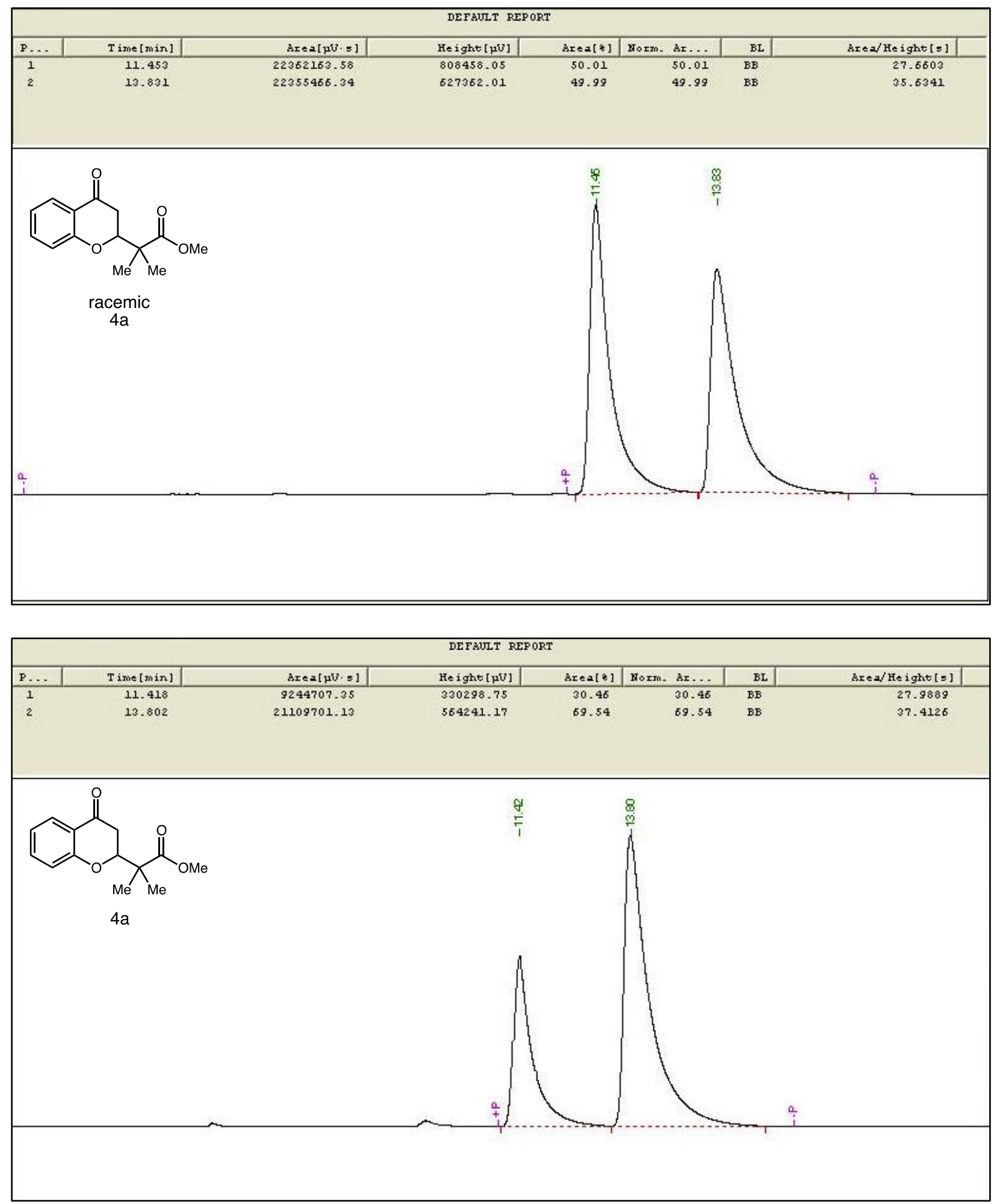

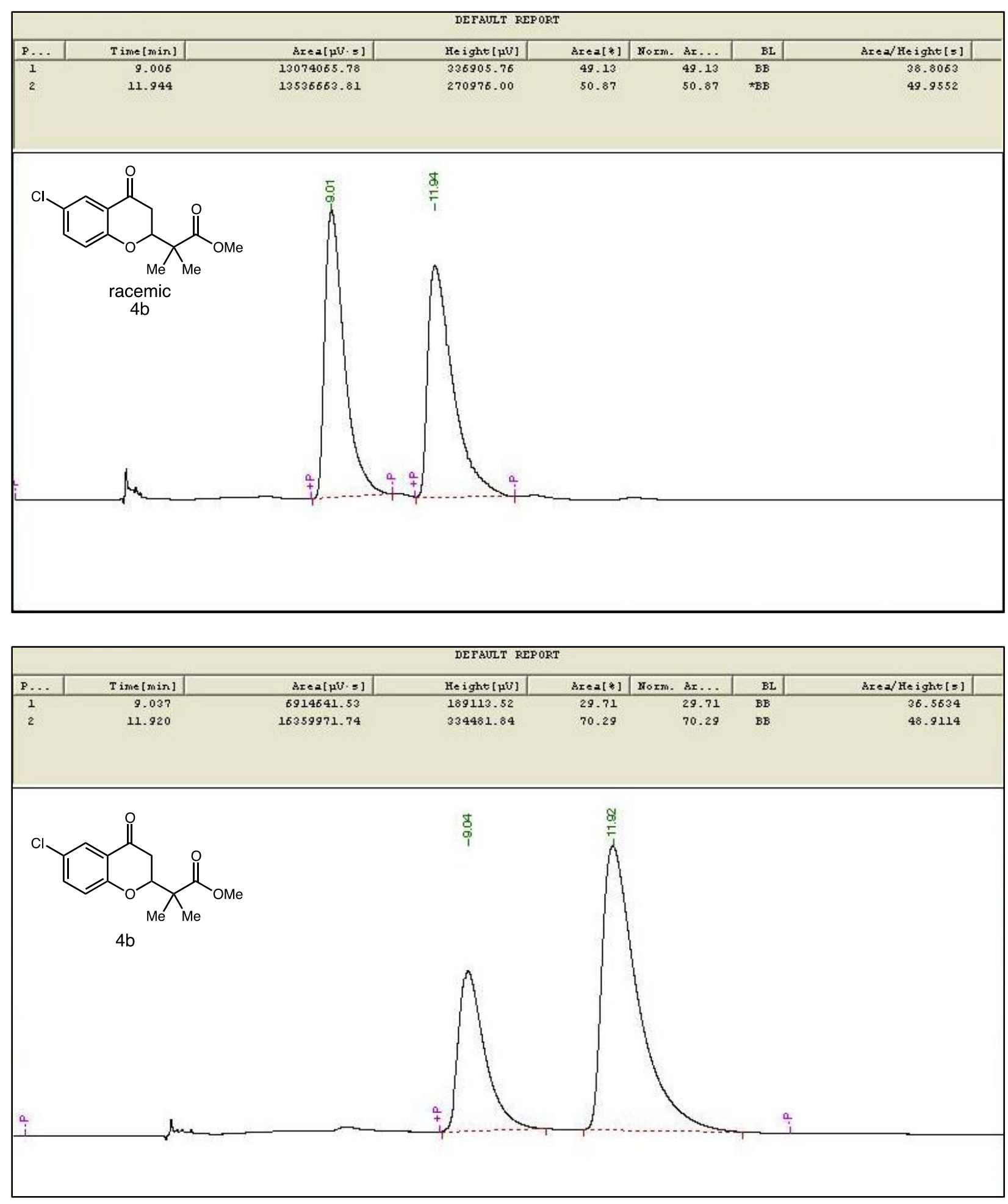

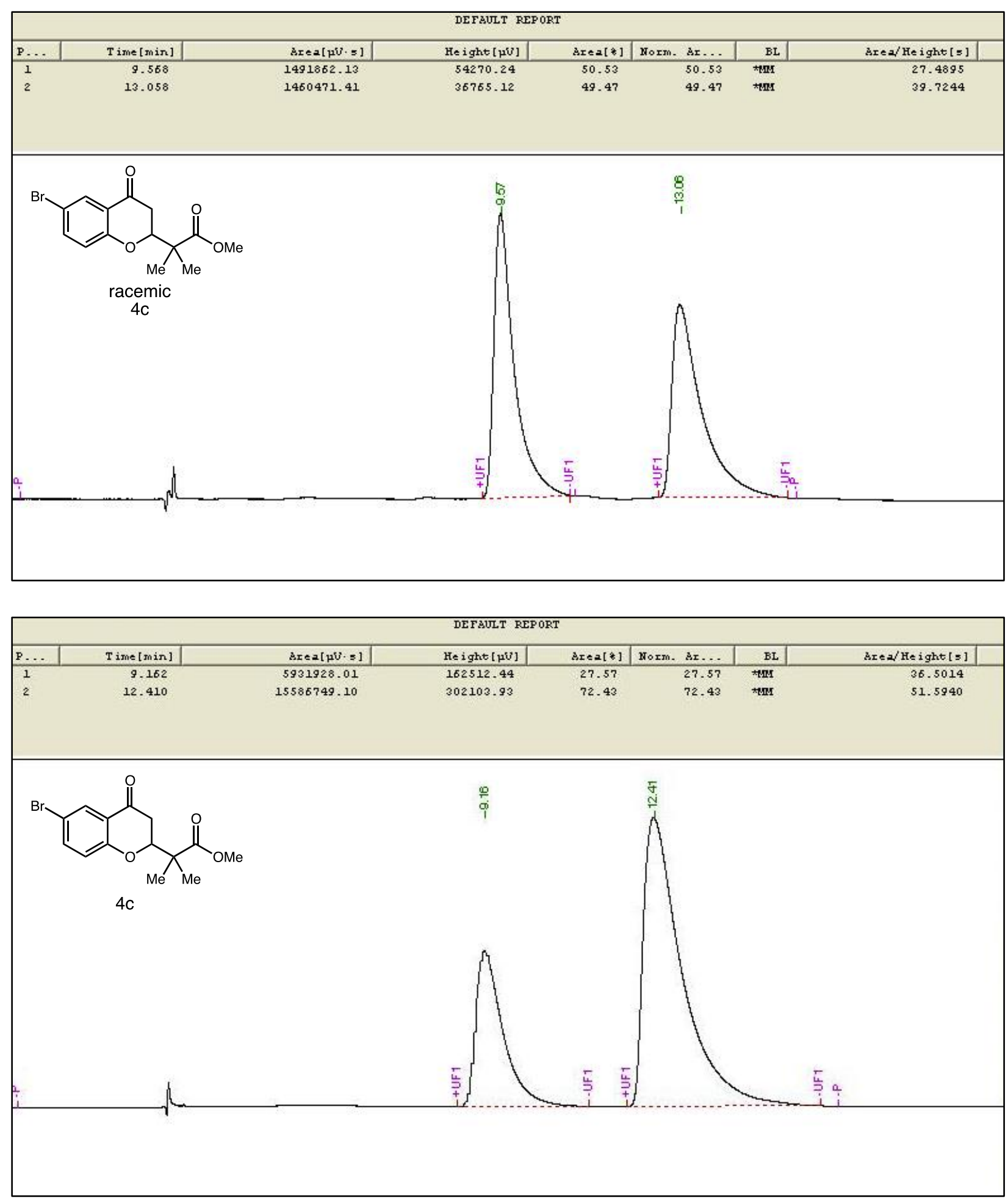


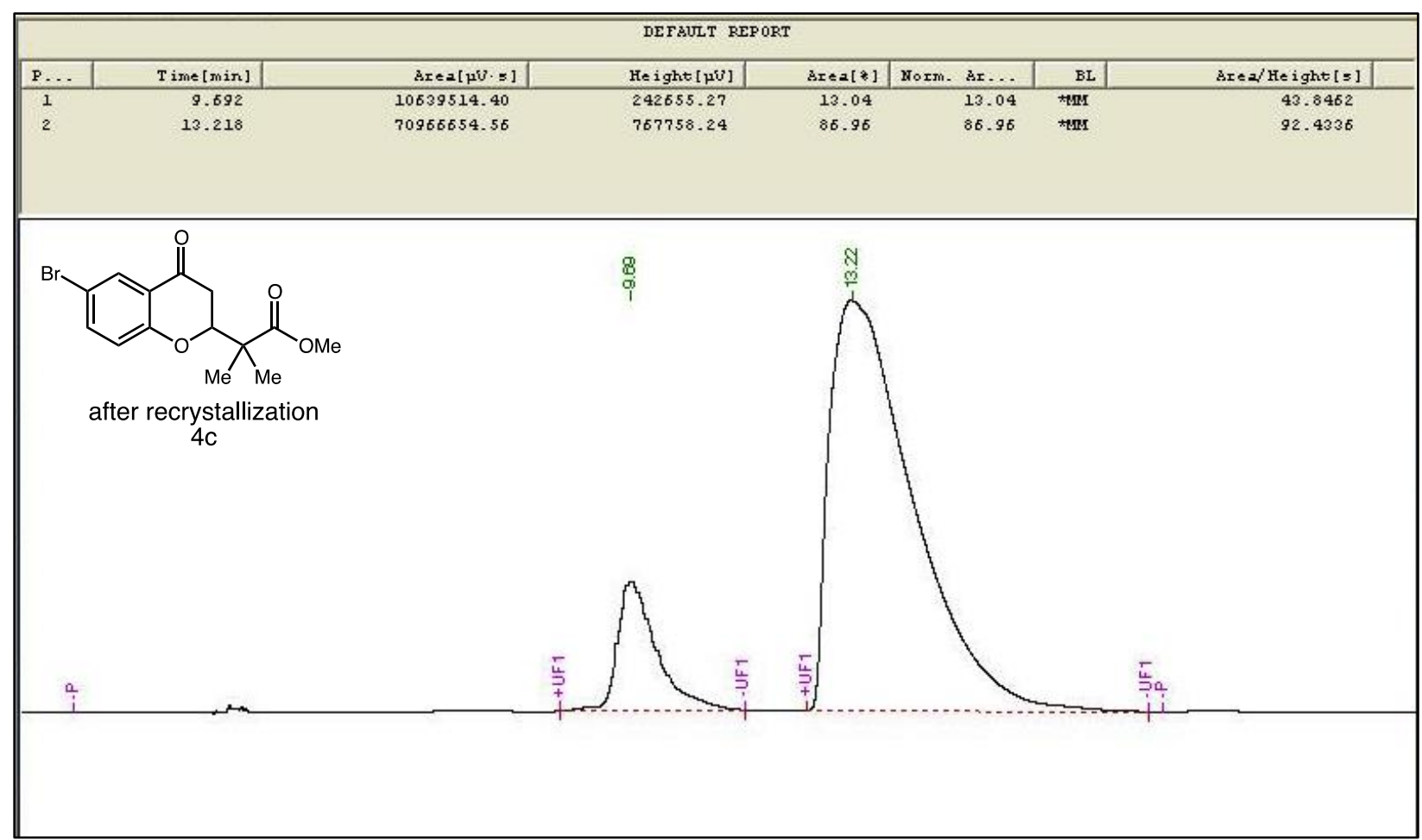



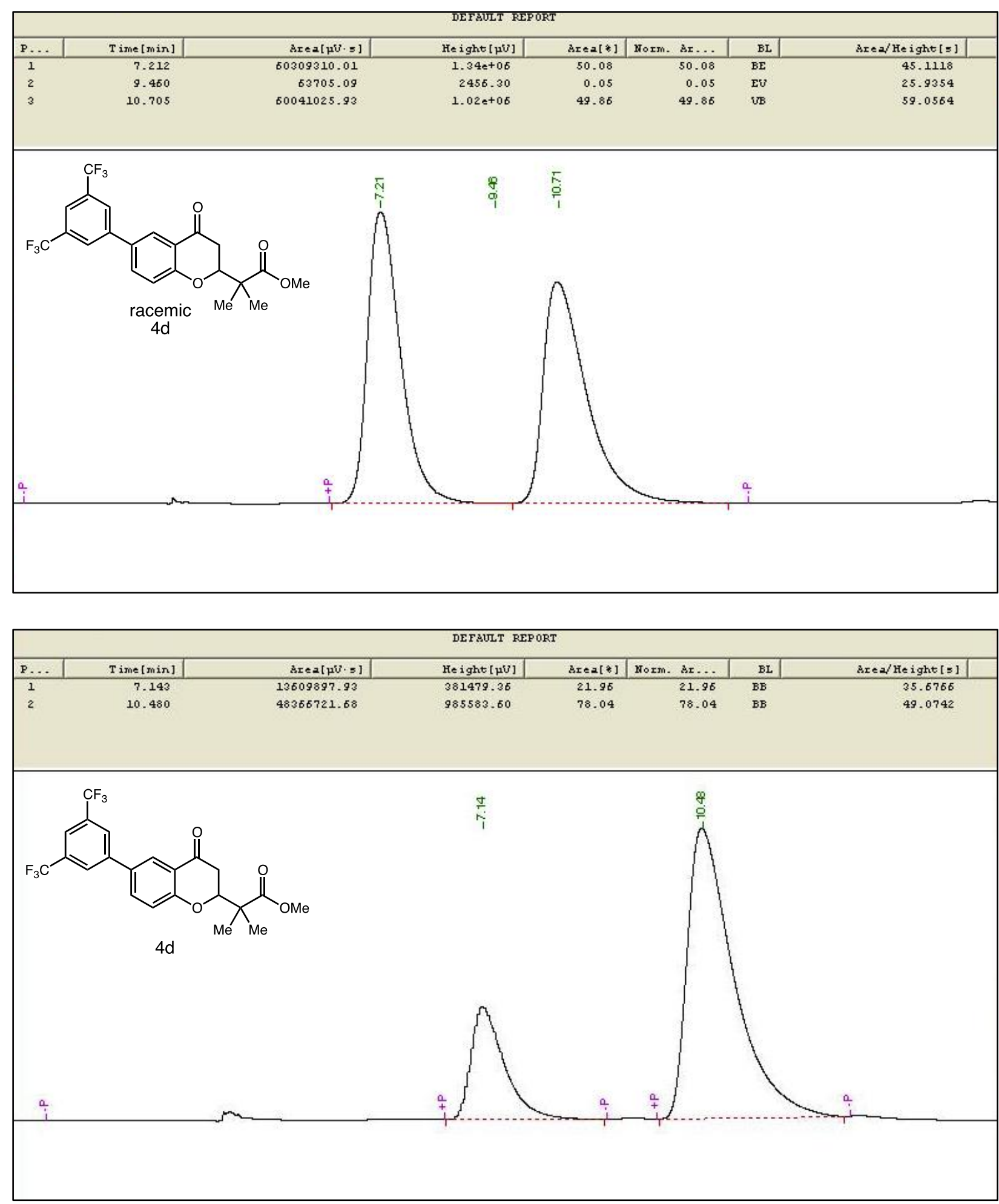

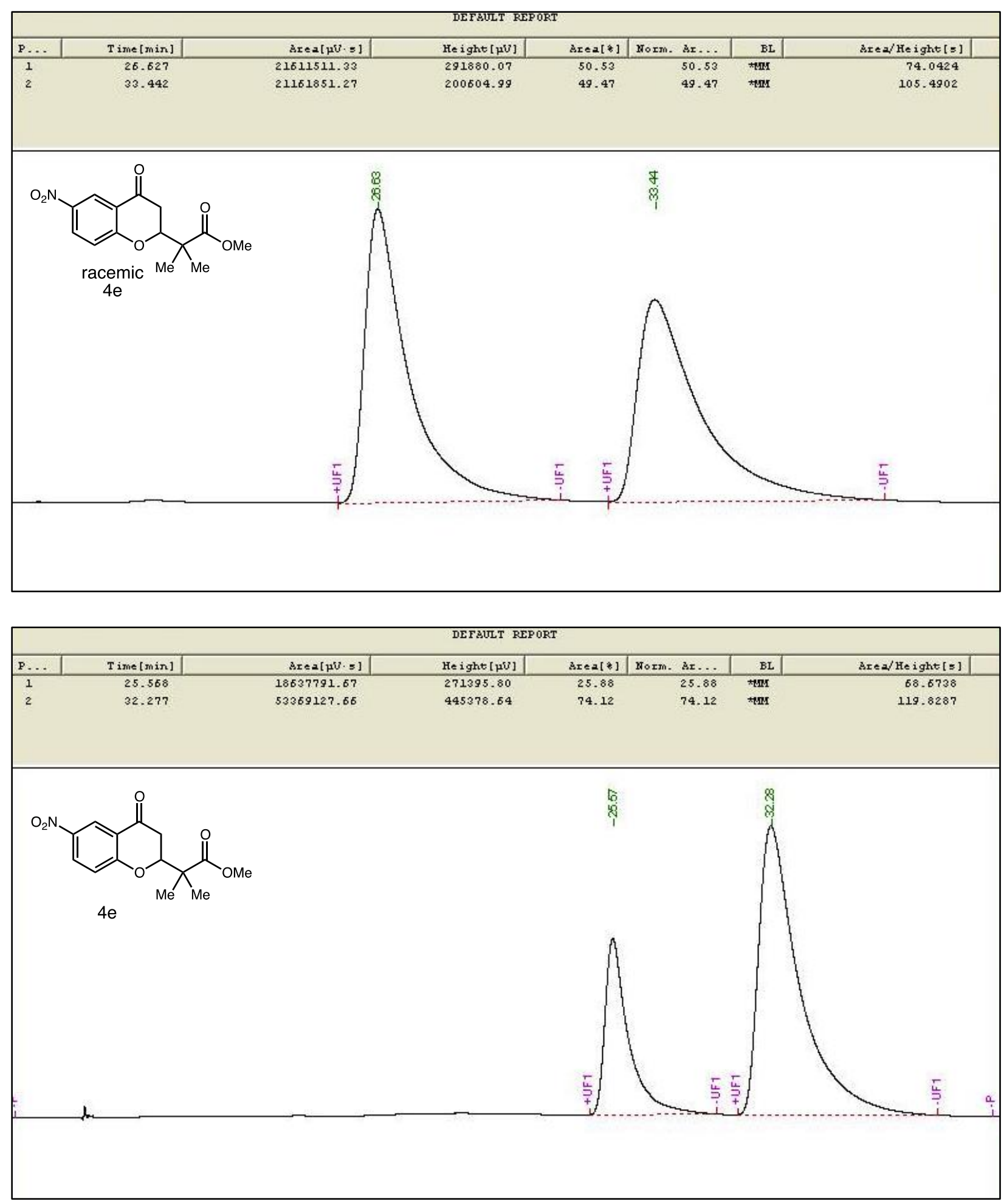

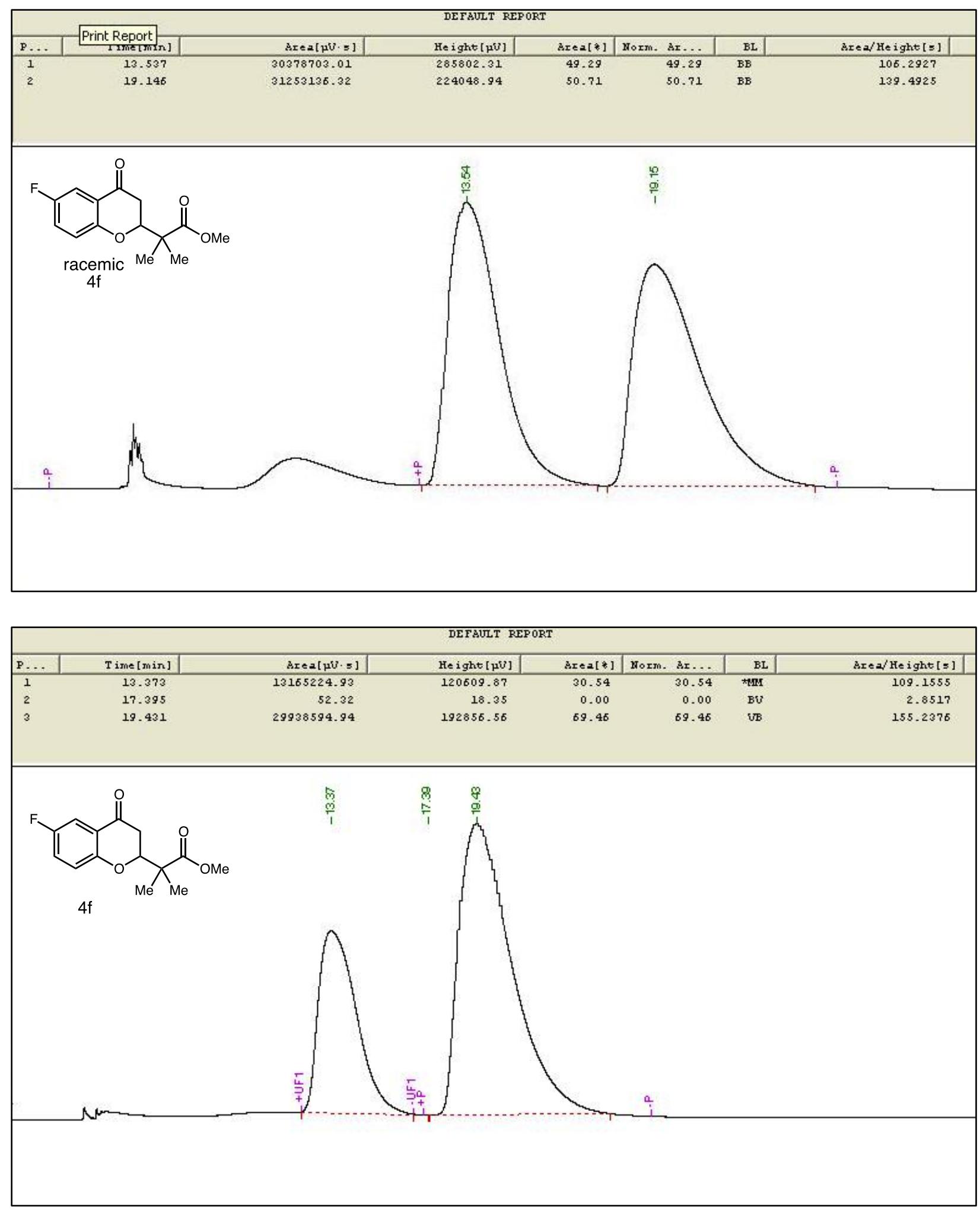

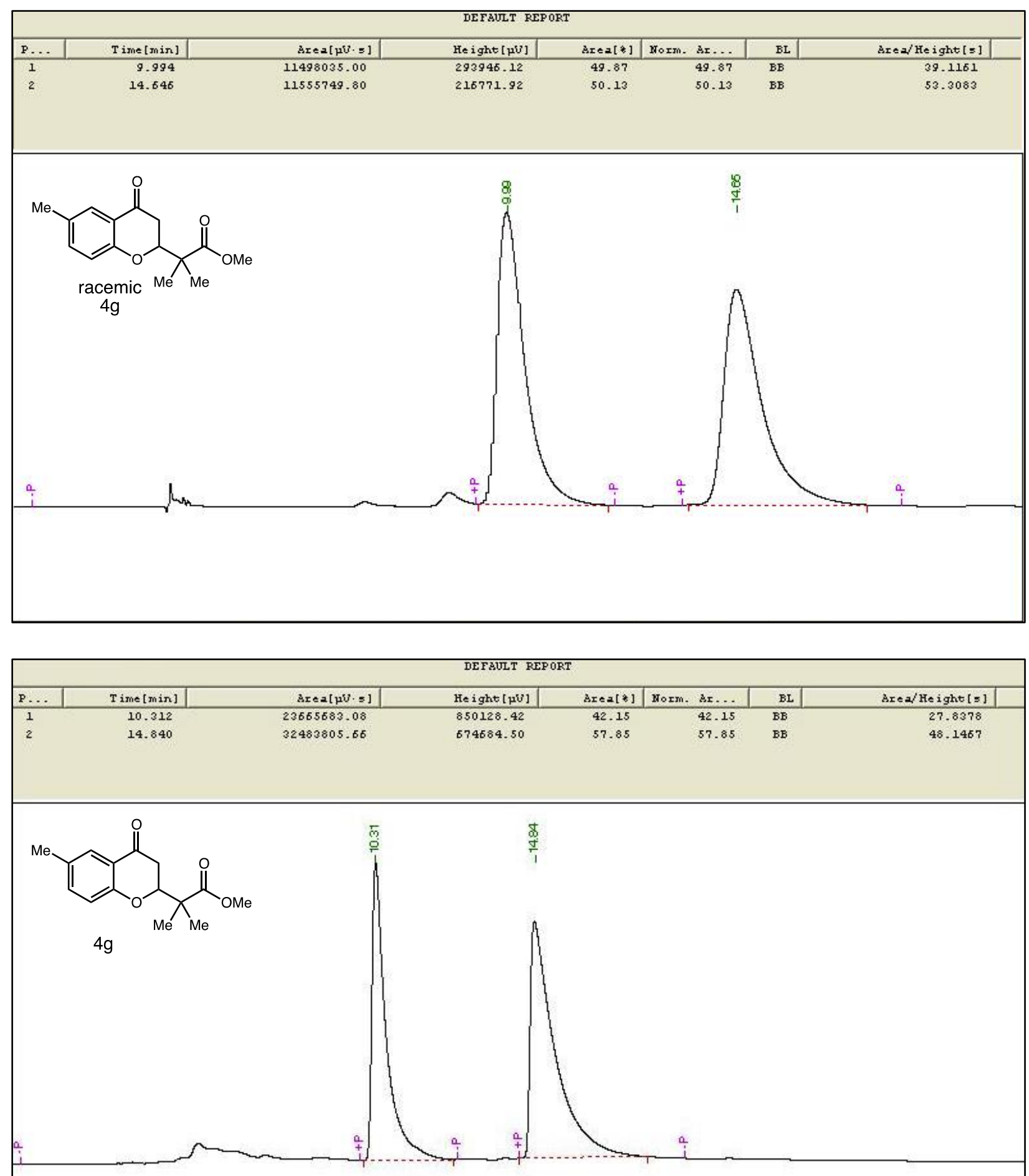

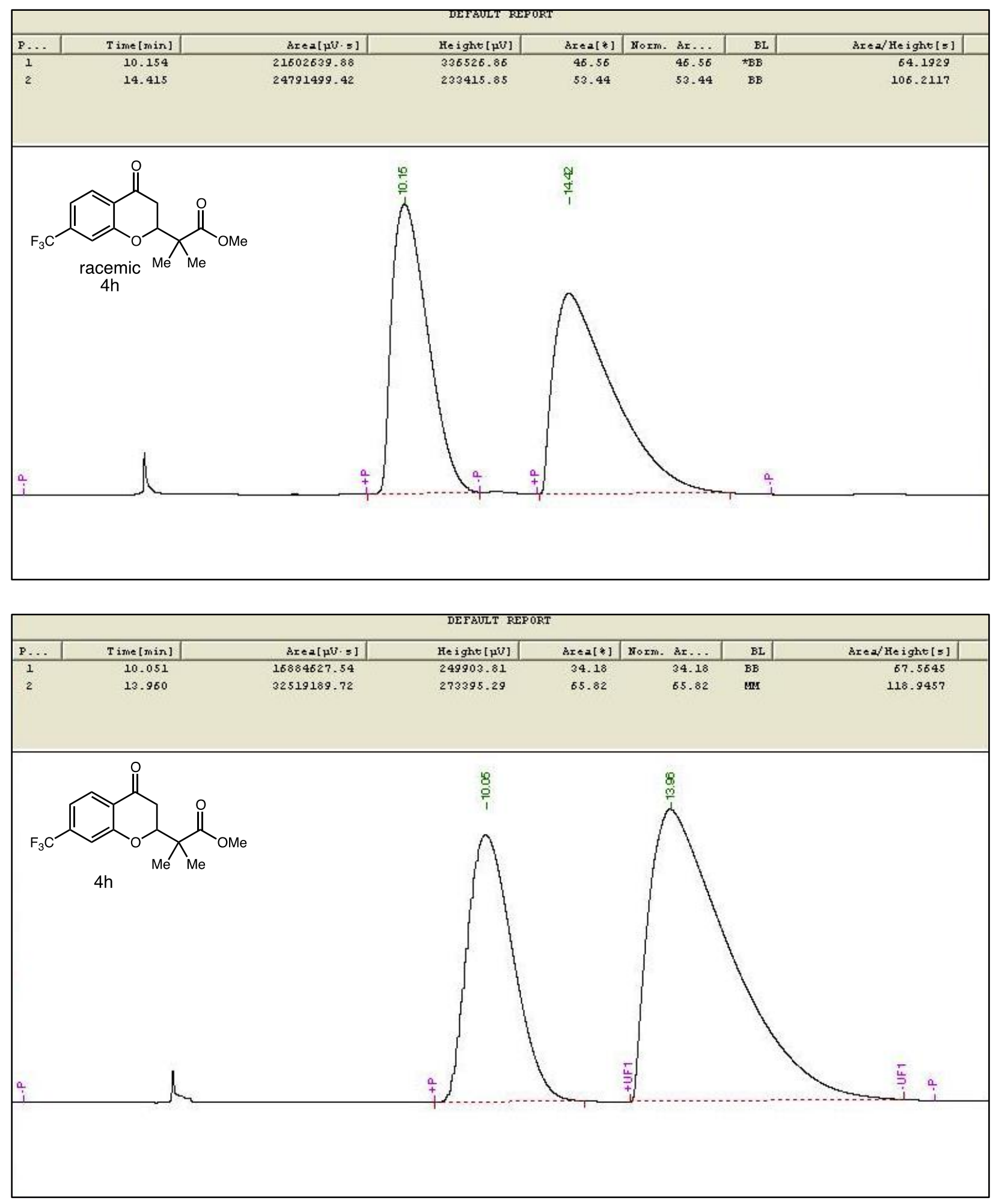

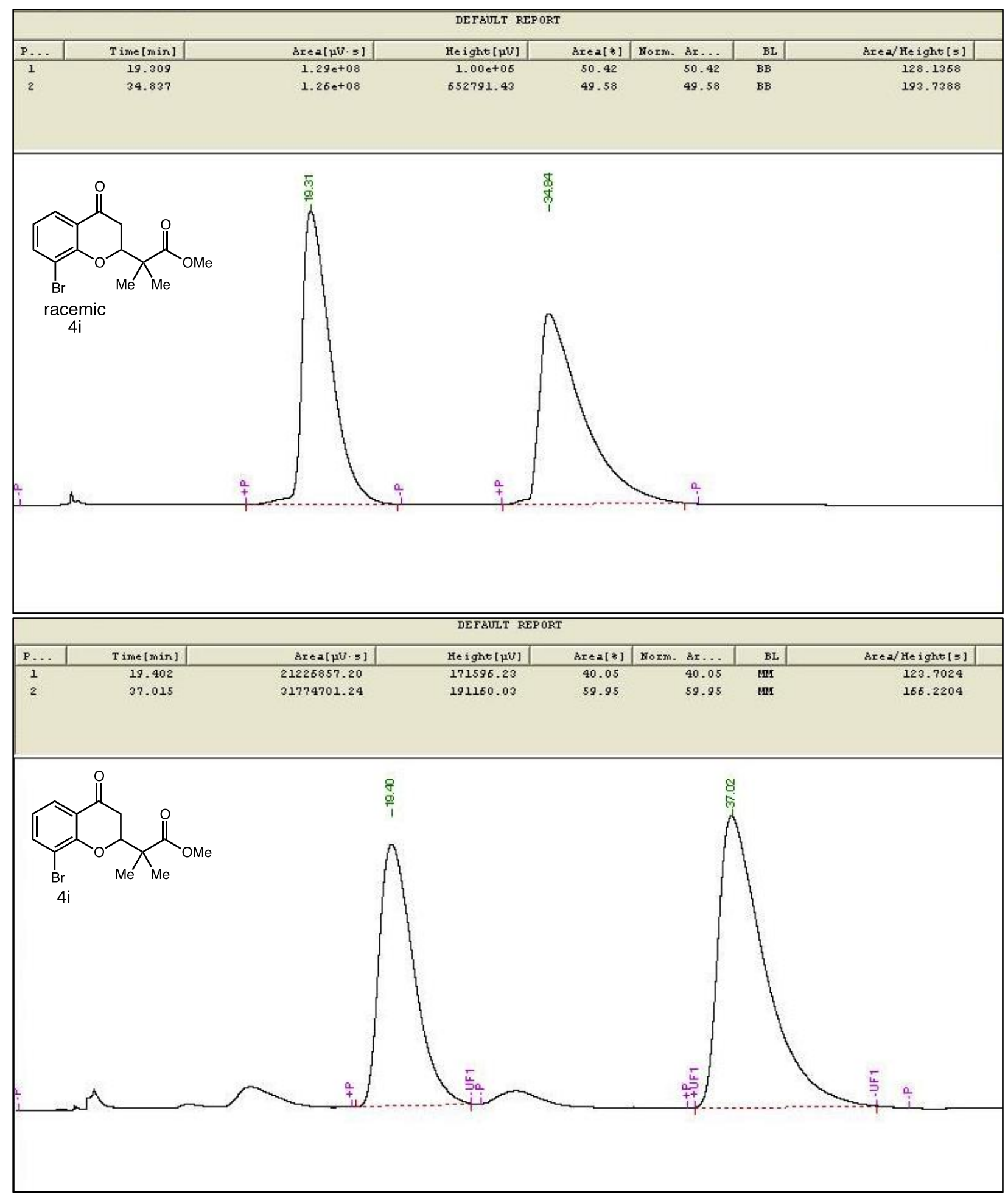


\section{Selected NMR Spectra}

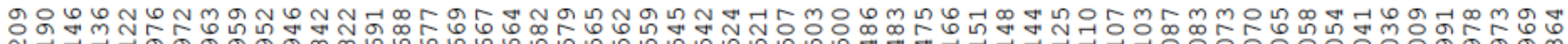
m m m m

क

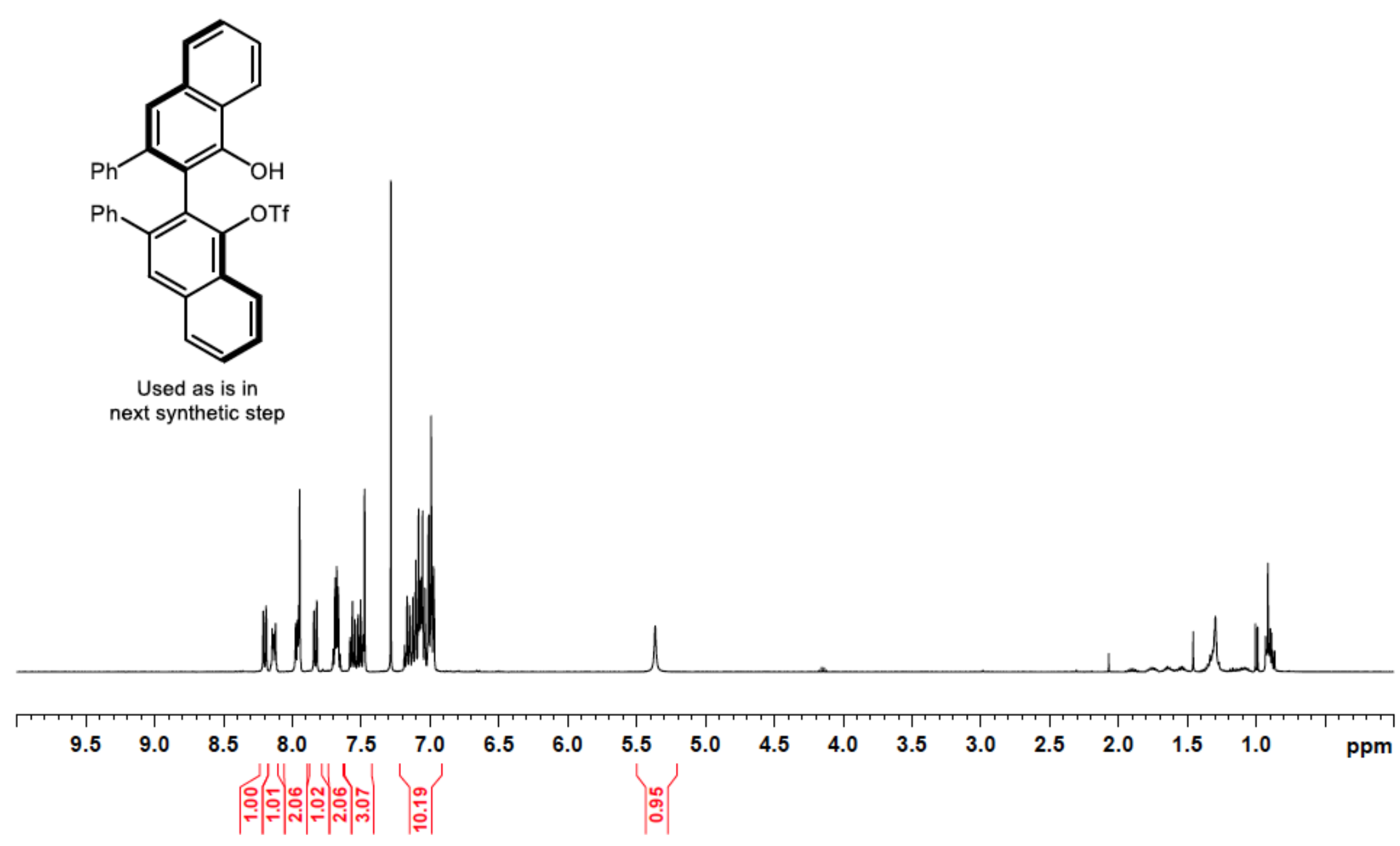




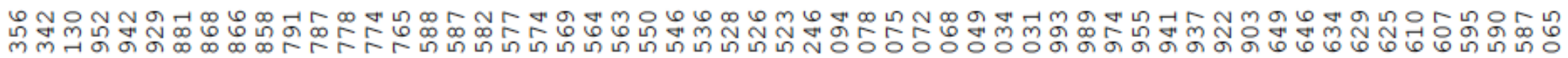

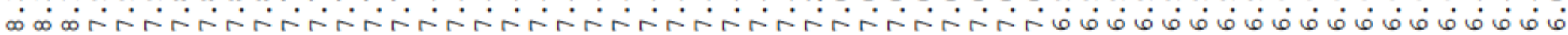

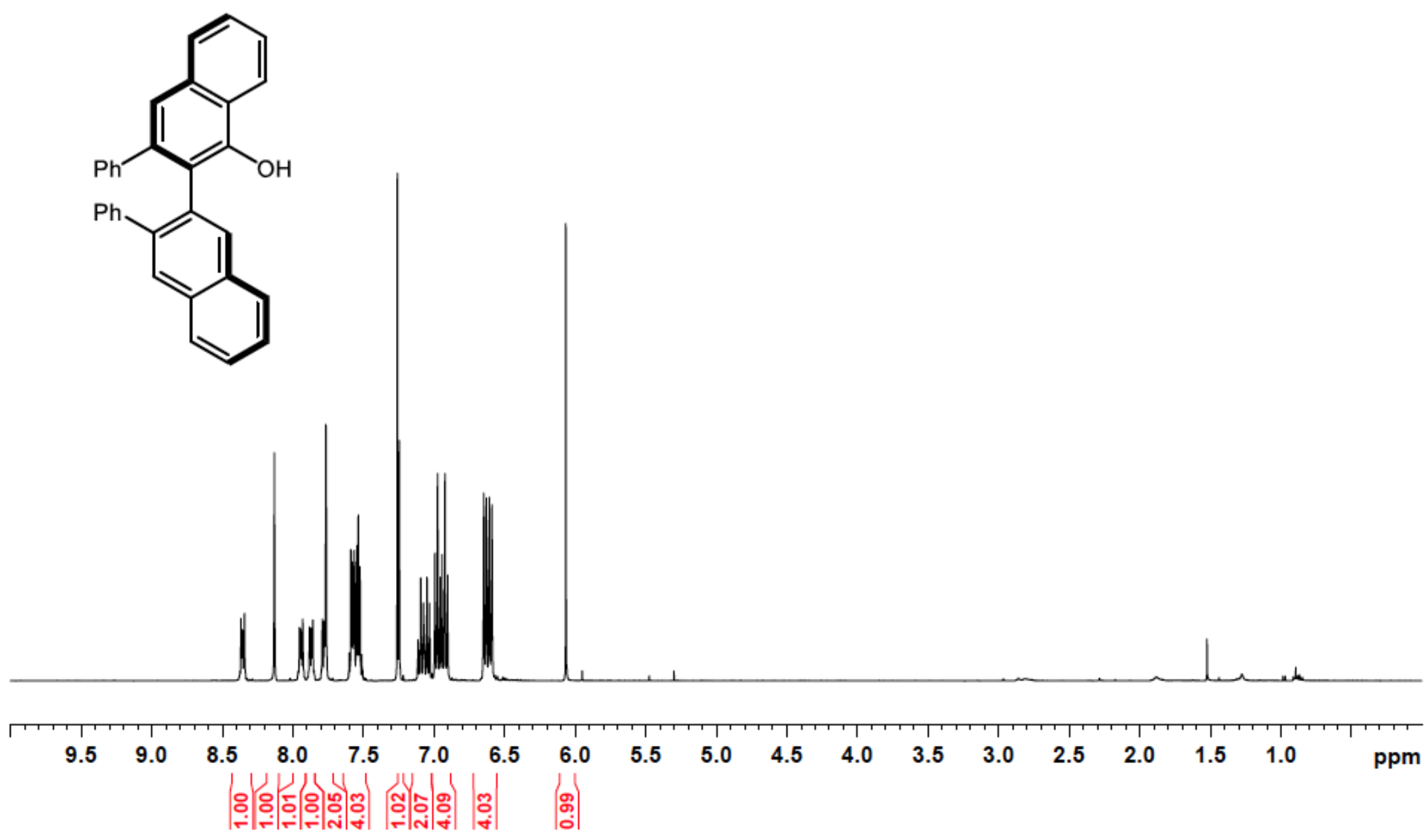




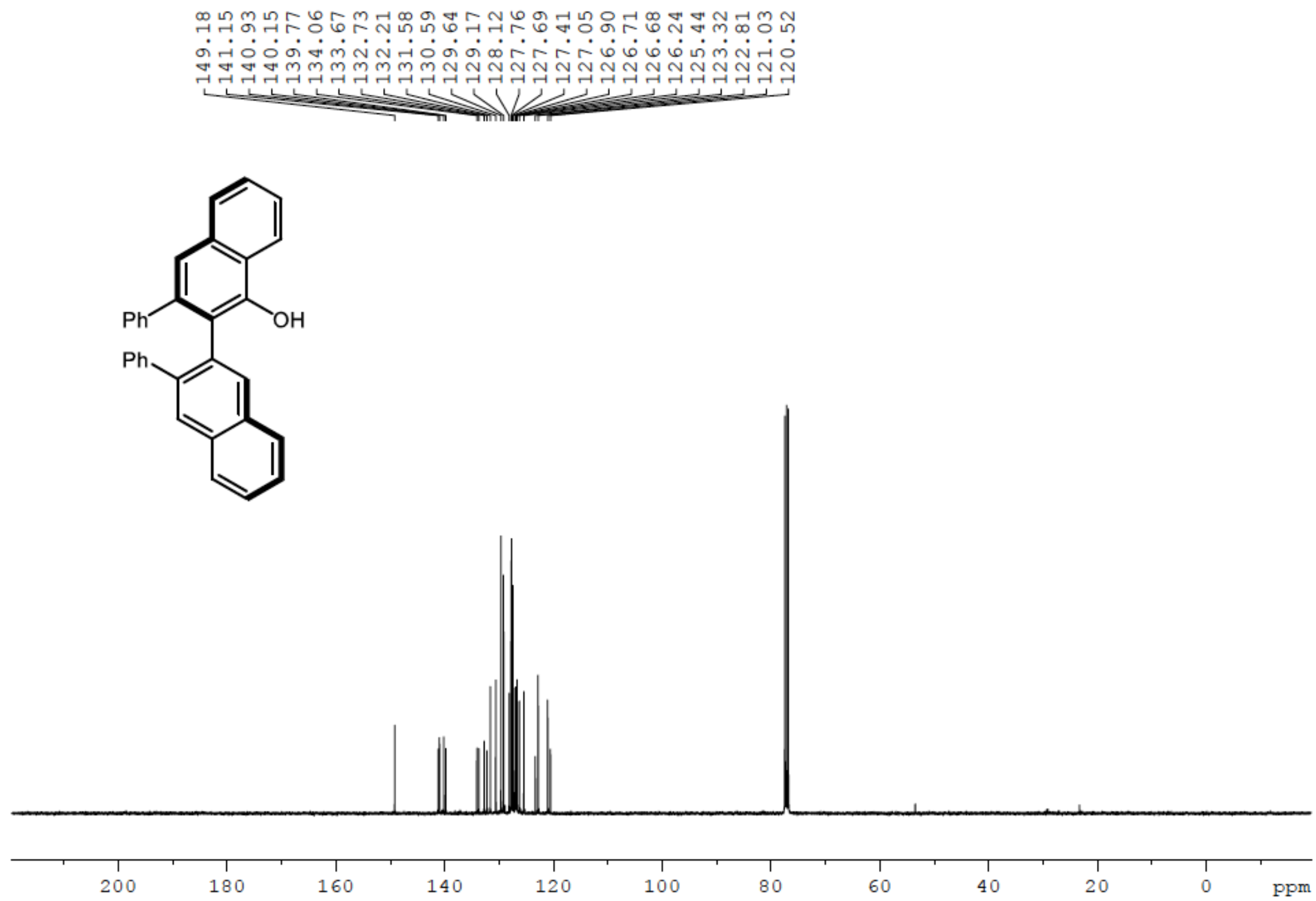




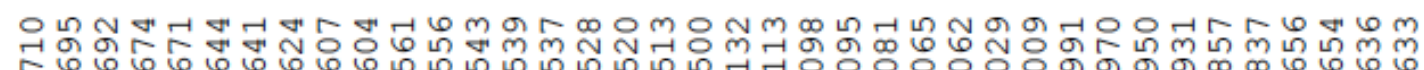

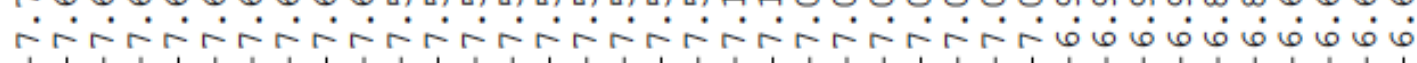

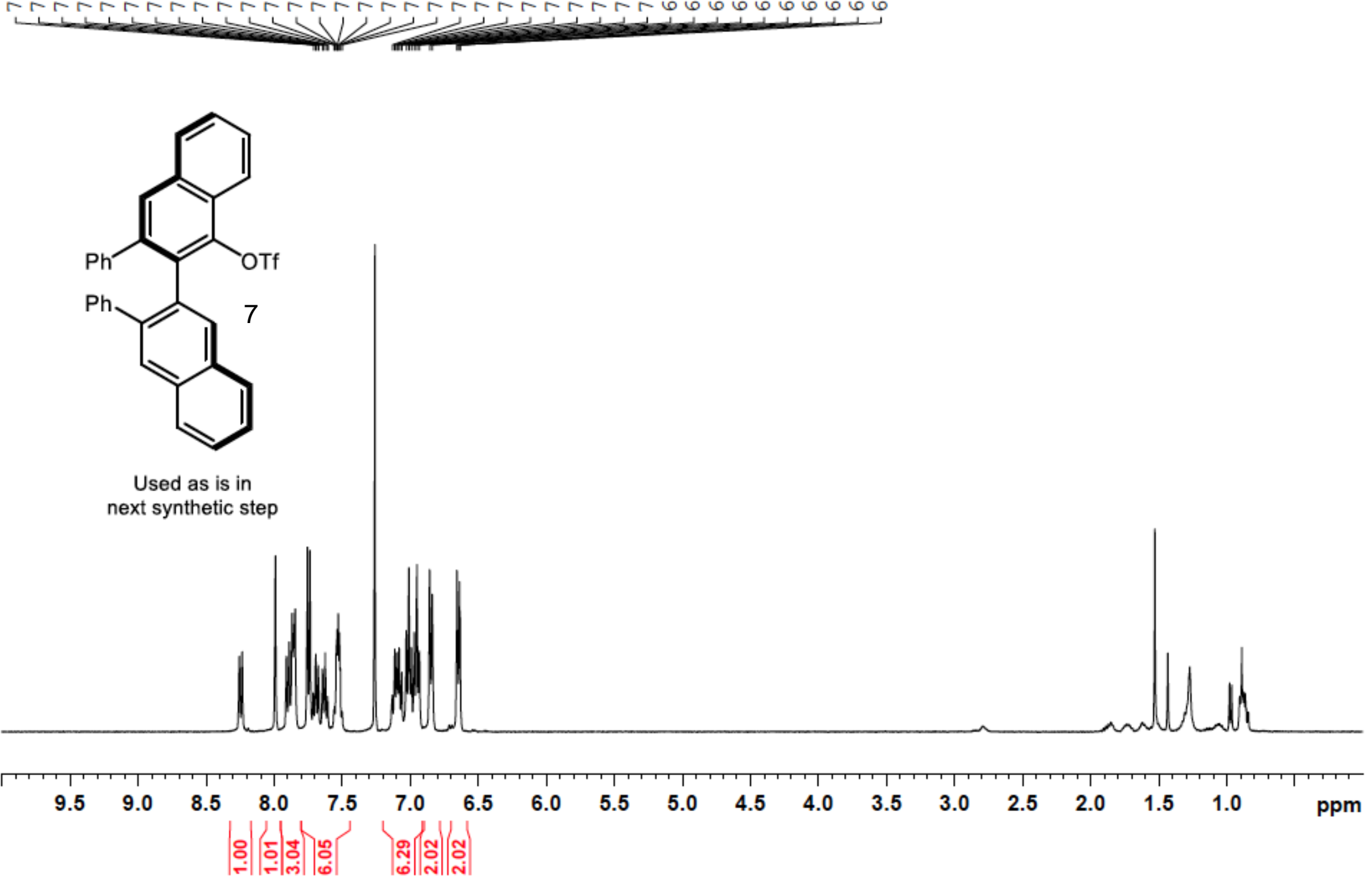




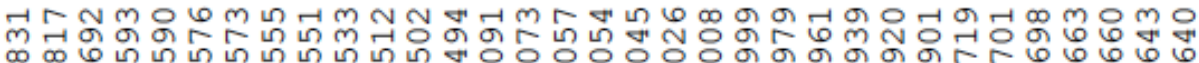

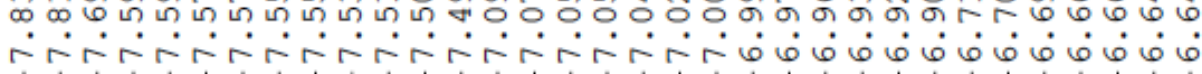
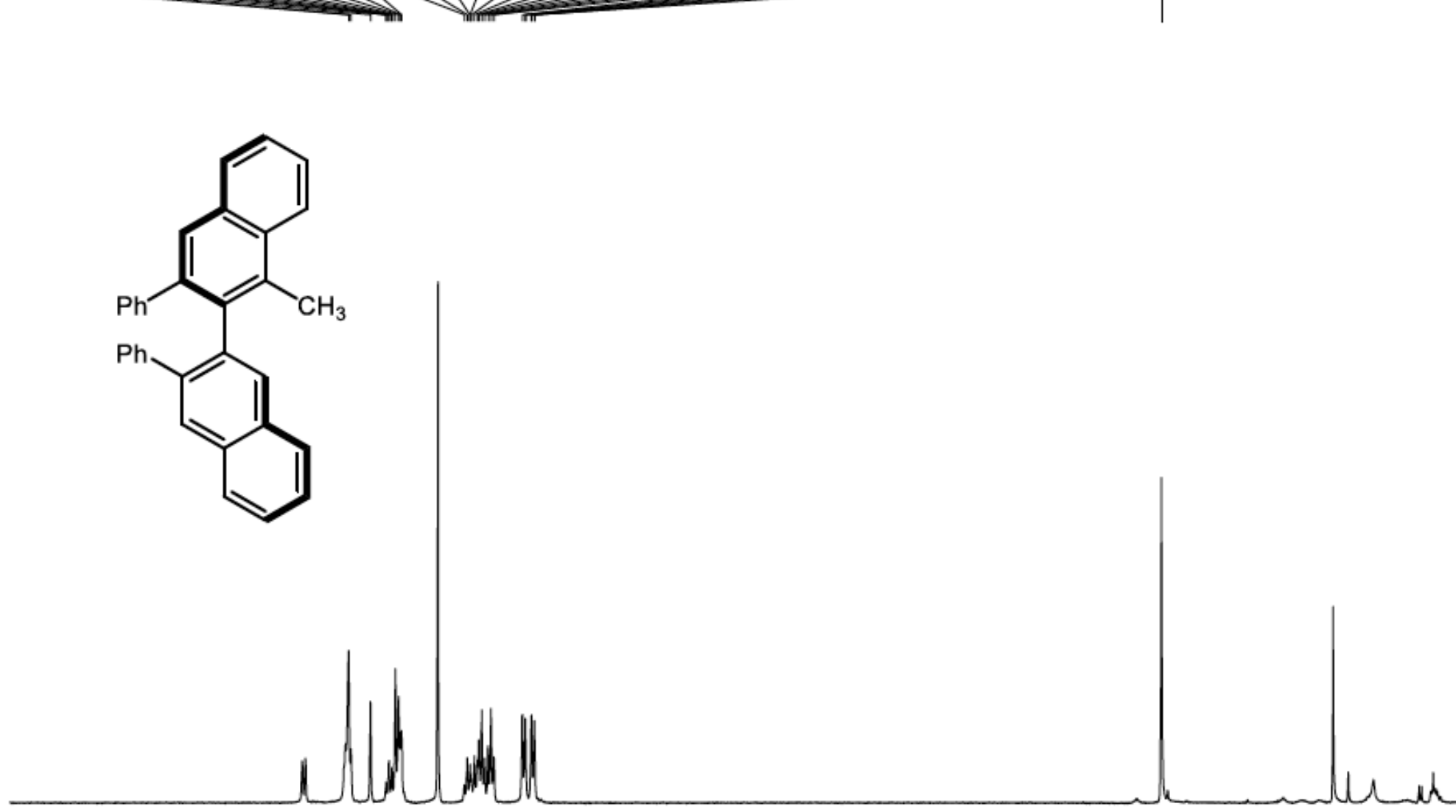

$9.5 \quad 9.0$

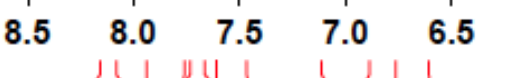

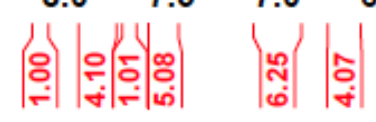

$\begin{array}{llll}6.0 & 5.5 & 5.0 & 4.5\end{array}$

$\begin{array}{llll}4.0 & 3.5 & 3.0 & 2.5\end{array}$

$\begin{array}{lll}2.0 & 1.5 & 1.0\end{array}$

ppm 


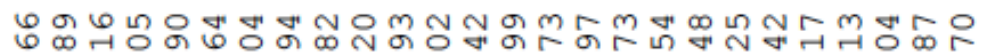

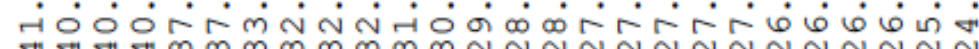

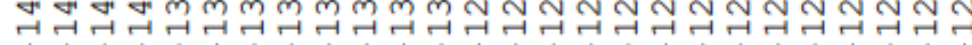

L

in 1 in<smiles>Cc1c(-c2cc3ccccc3cc2-c2ccccc2)cc2ccccc2c1-c1ccccc1</smiles>
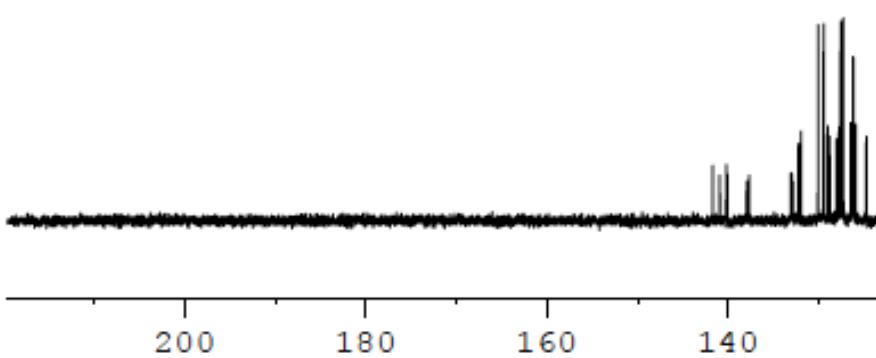

140

120

100

80

60

40

20

$\mathrm{ppm}$ 


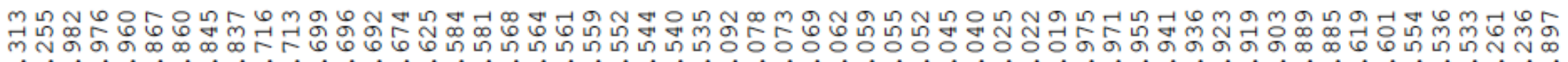

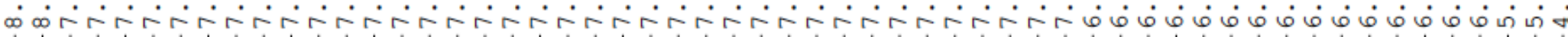

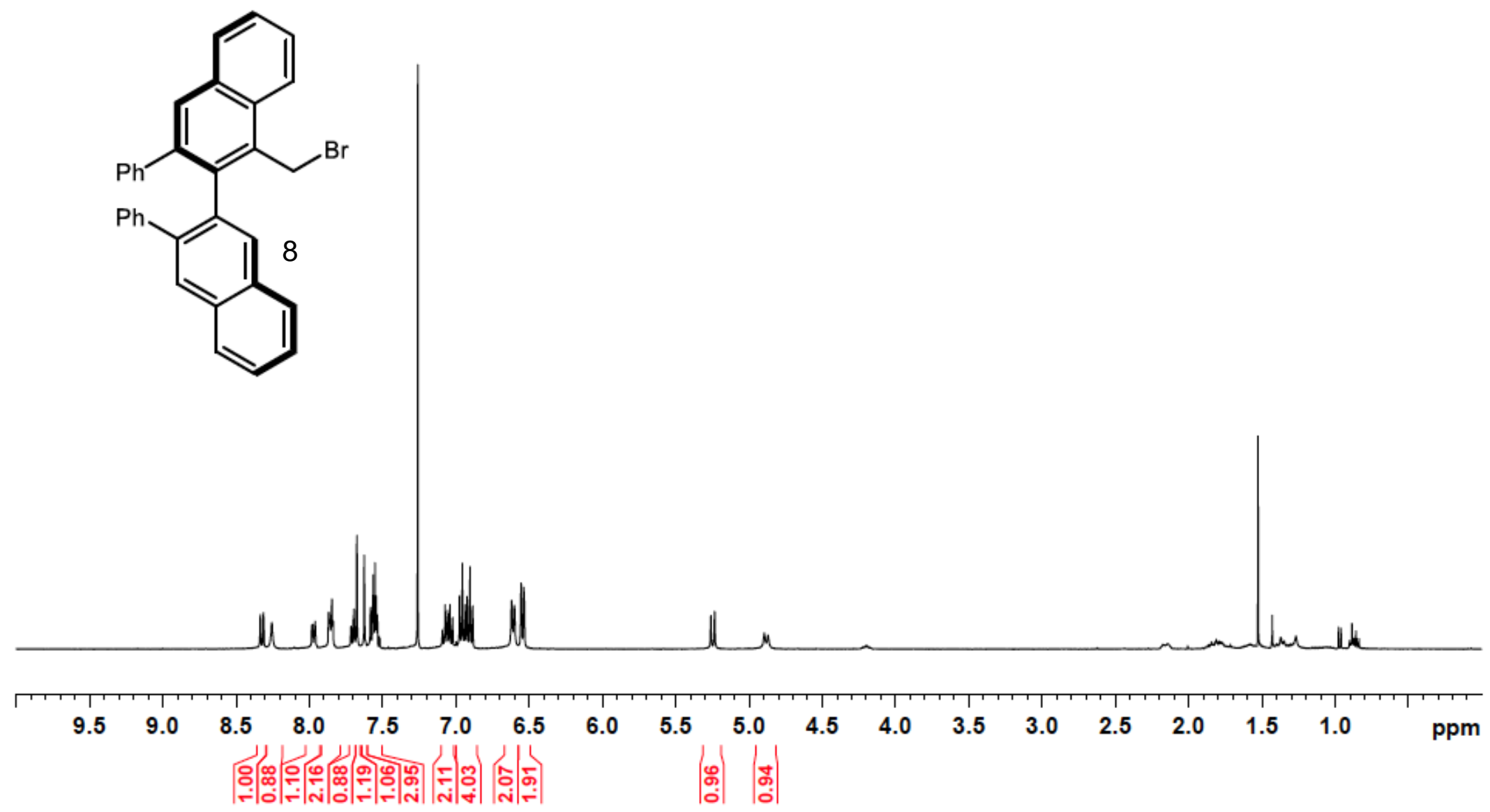




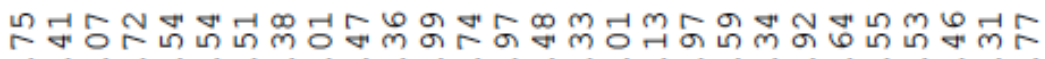

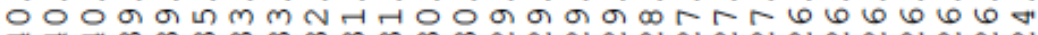

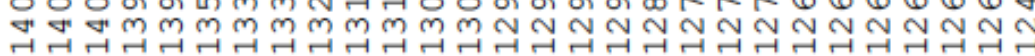

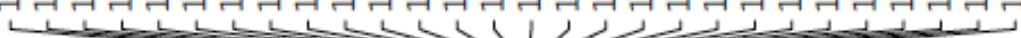

sin- 17 min

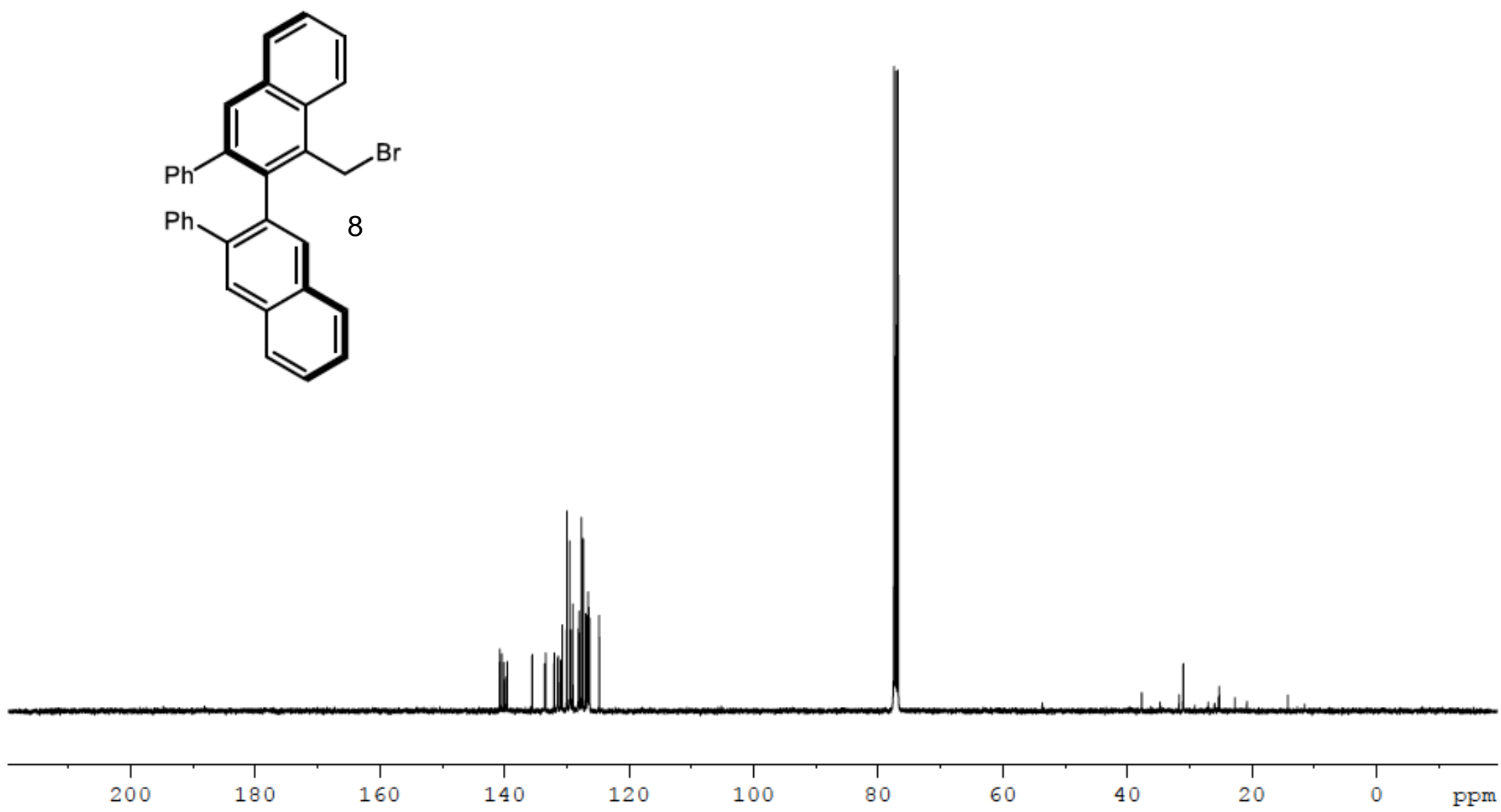




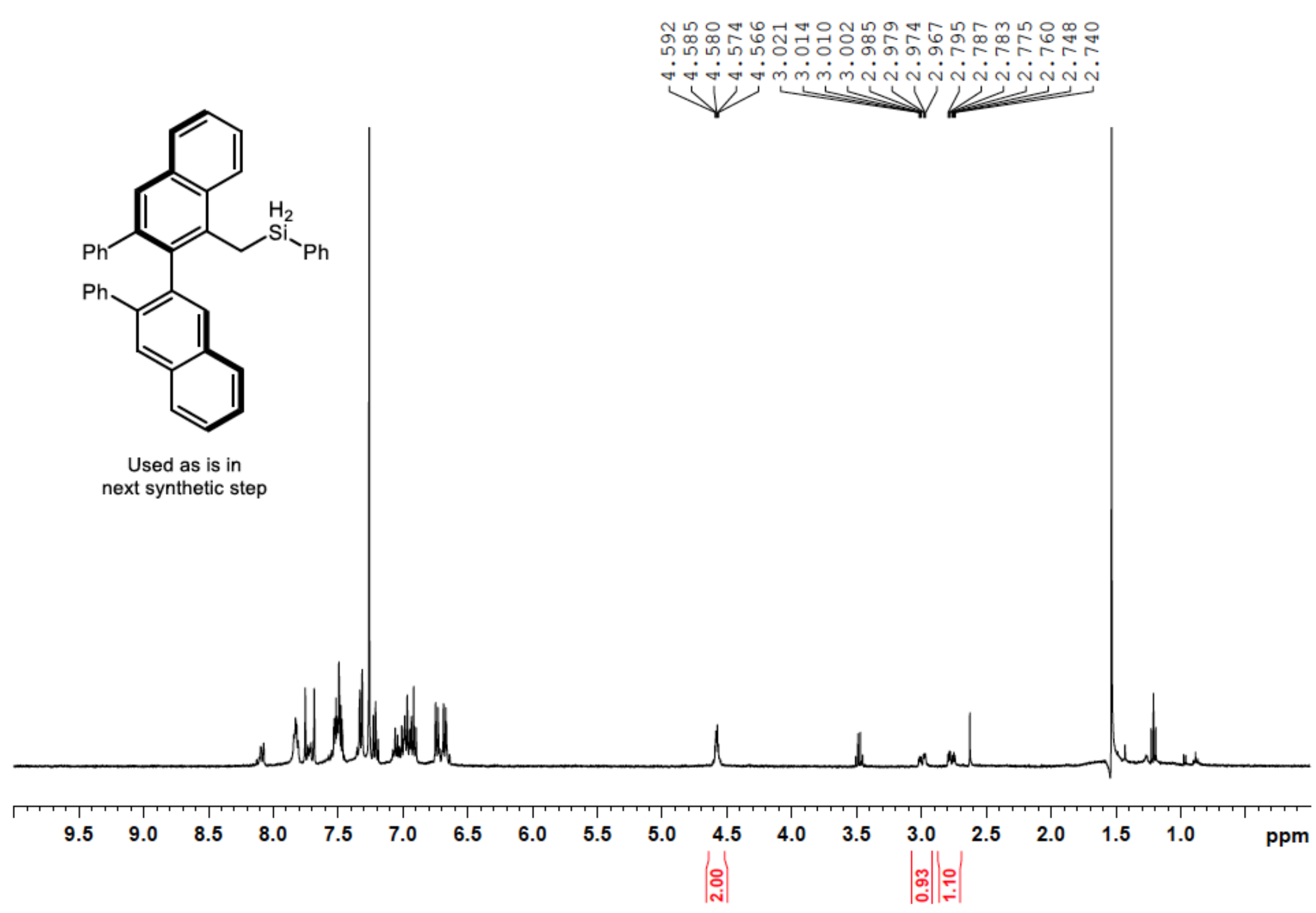




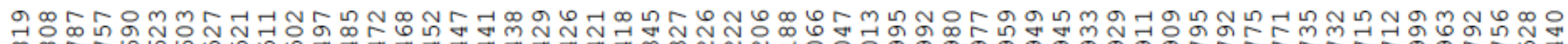

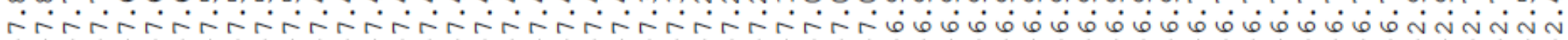

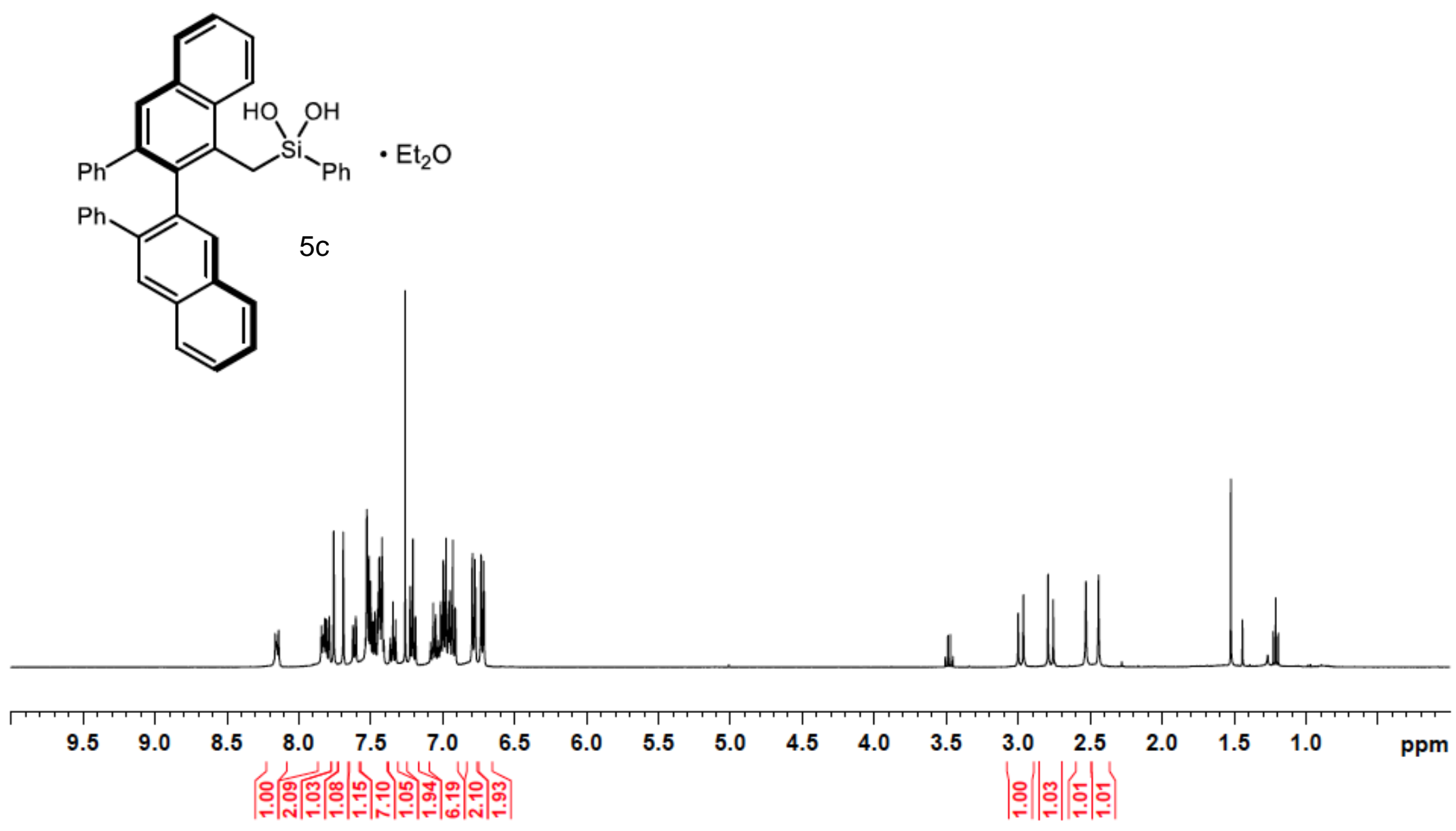




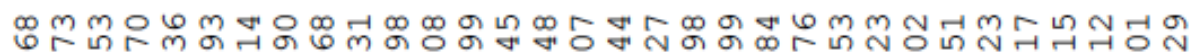

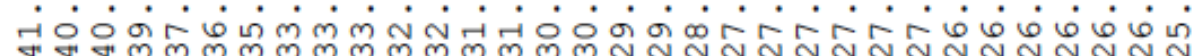

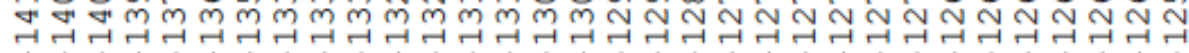

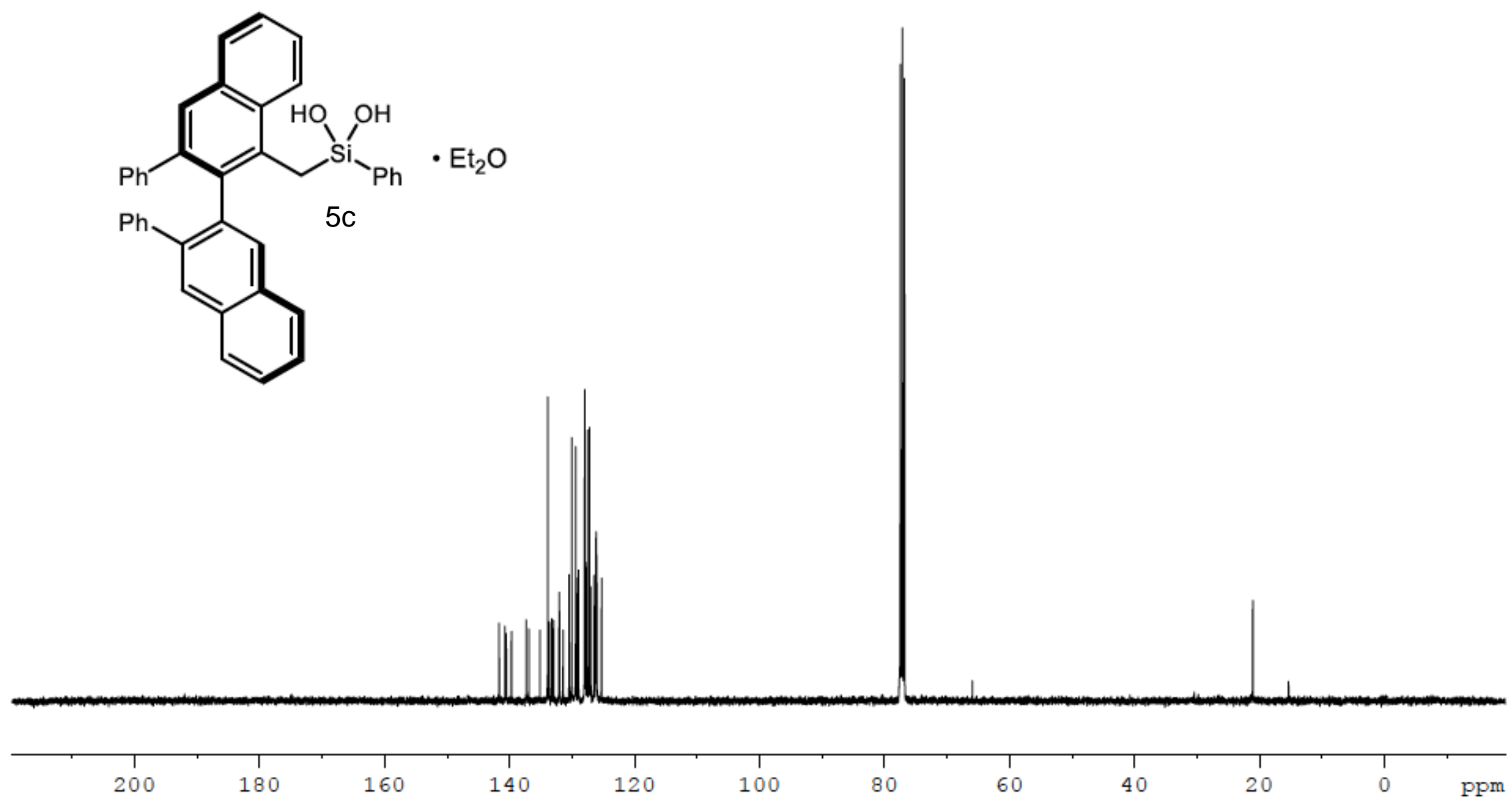


స్ำై

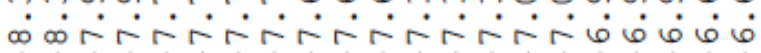

$1+1$<smiles>Oc1c(-c2ccccc2)c(-c2cc3ccccc3cc2-c2ccccc2)c(O)c2ccccc12</smiles>

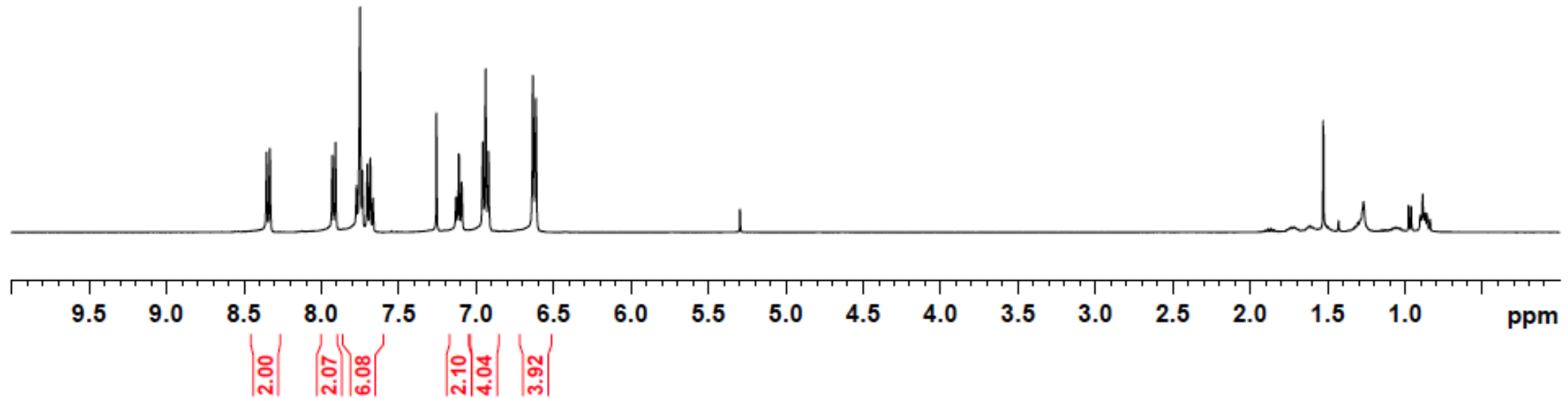



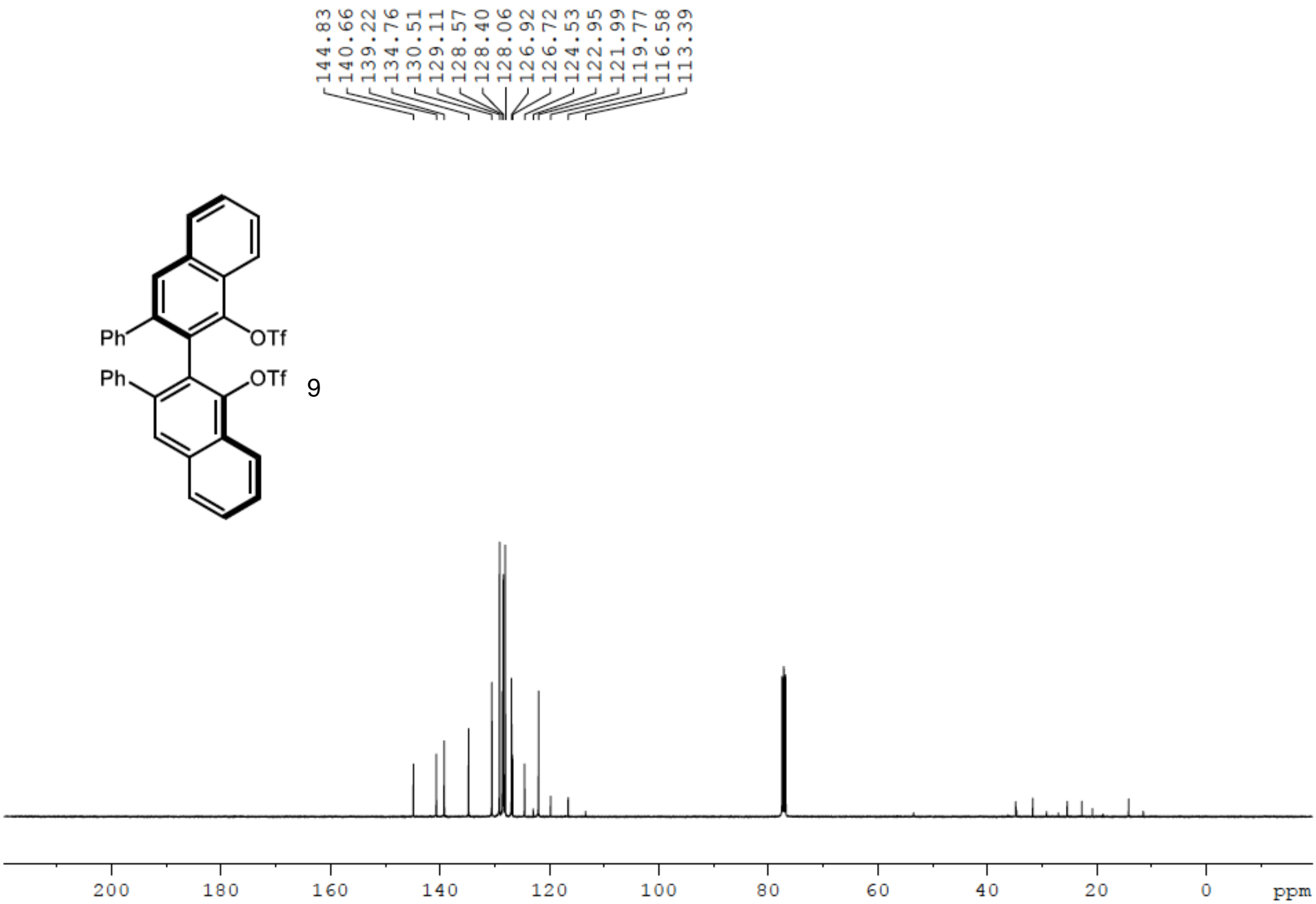


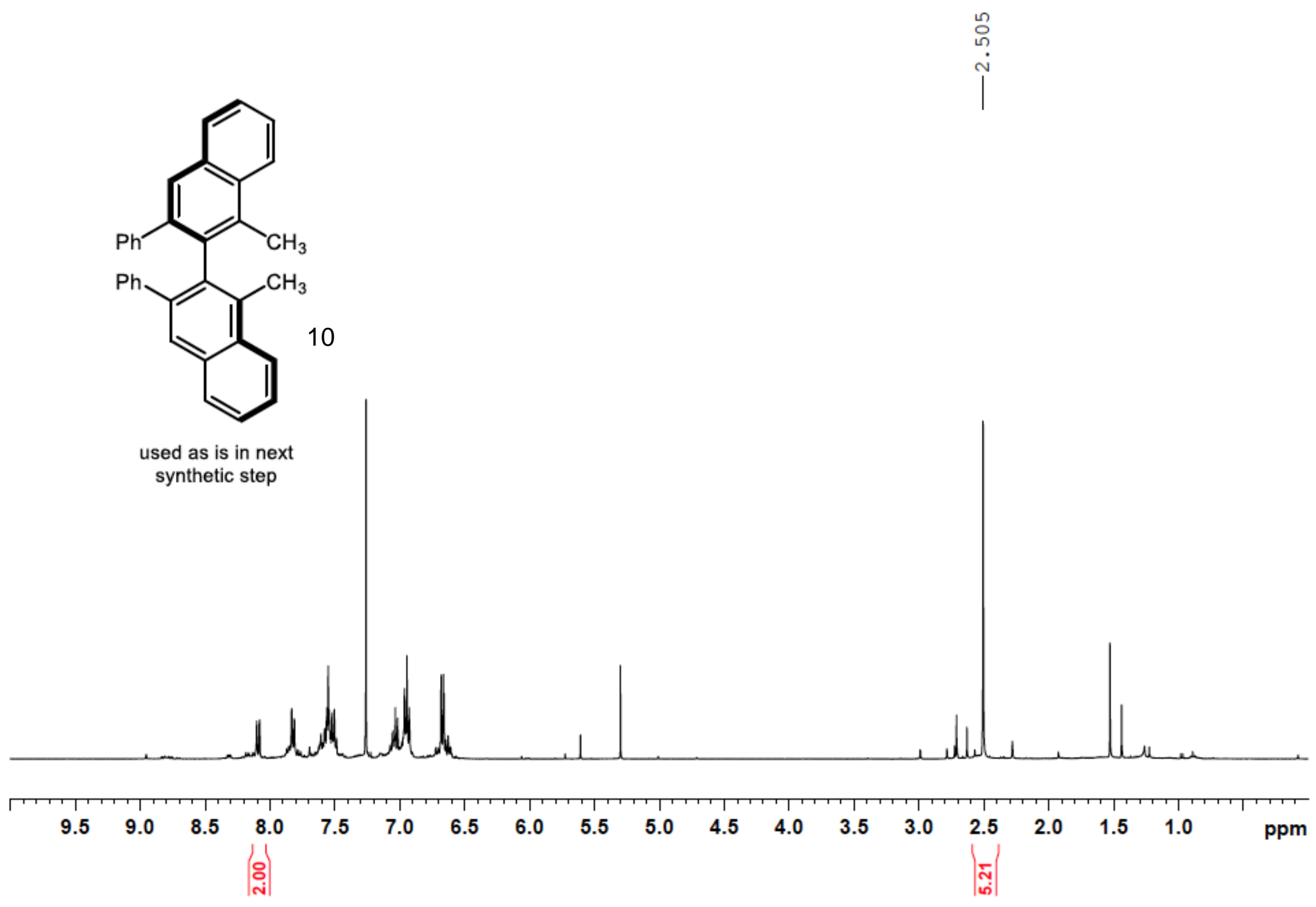




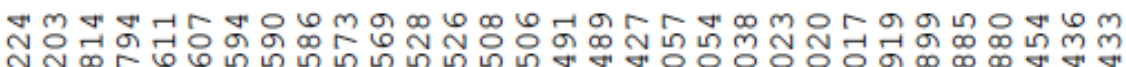

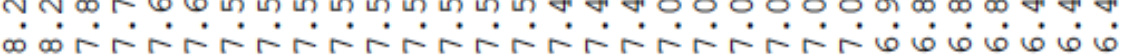

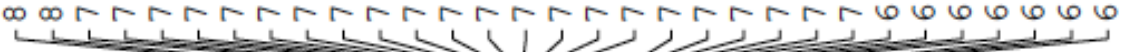<smiles></smiles>

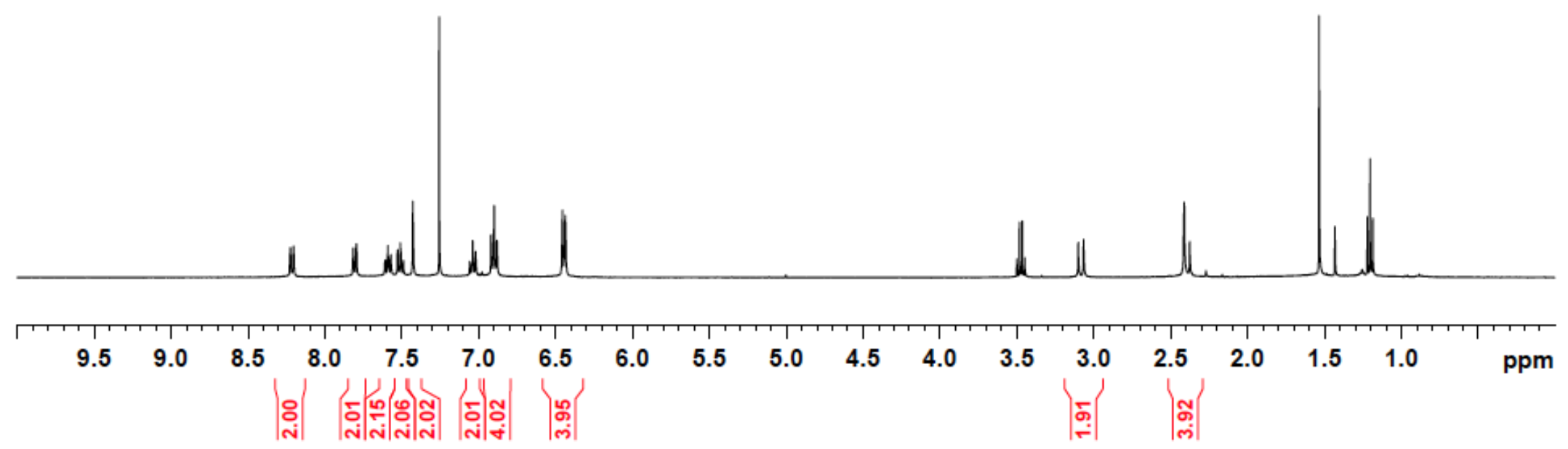



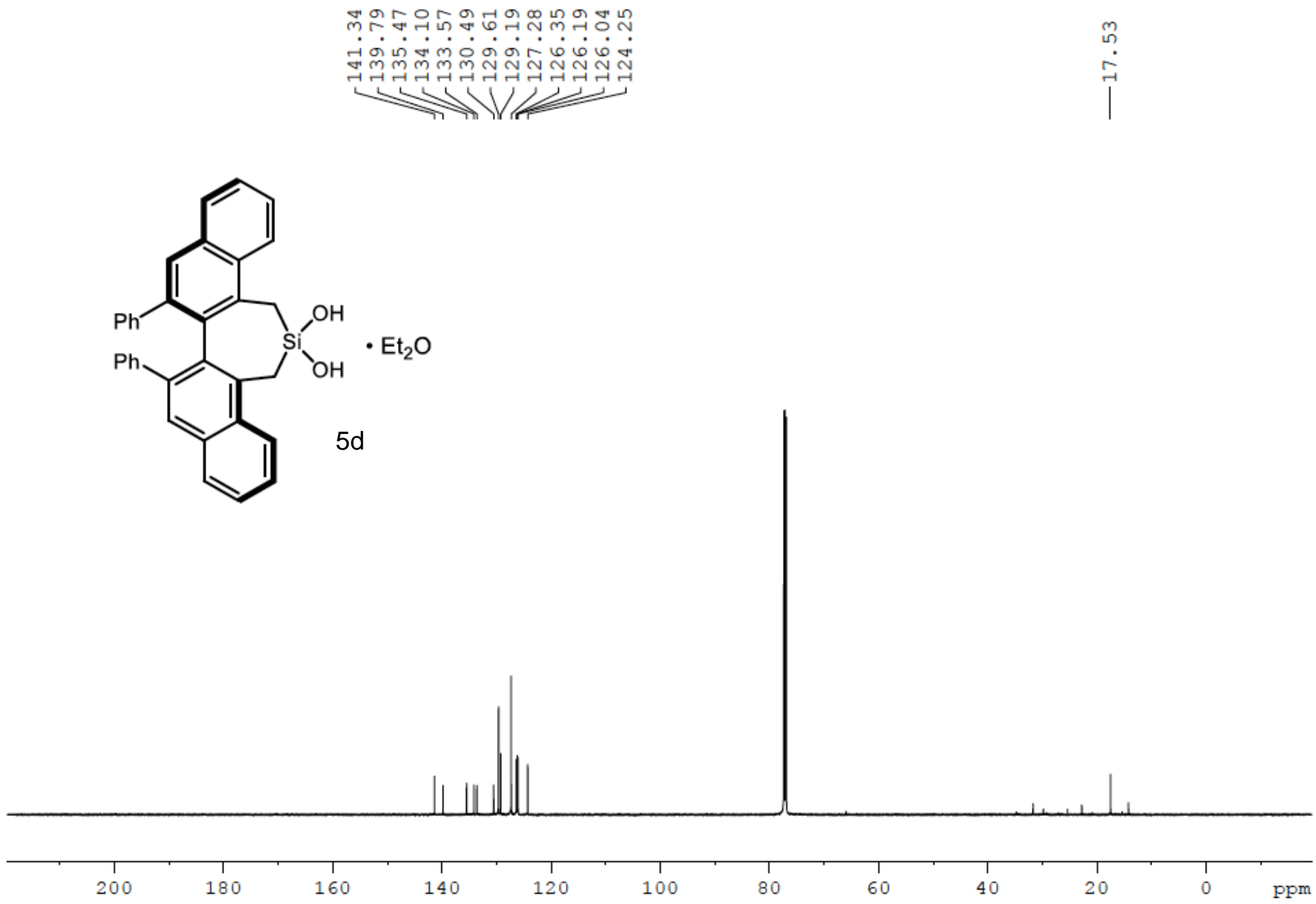


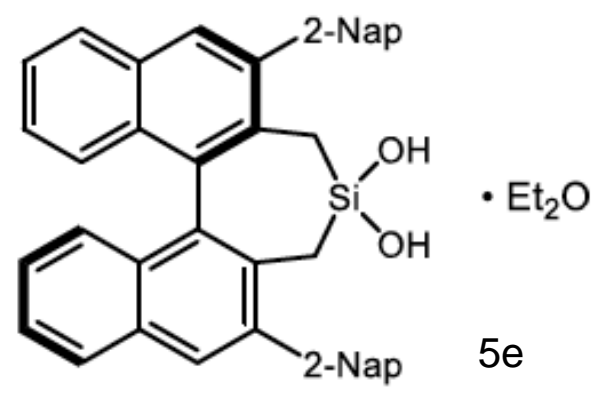

$5 e$

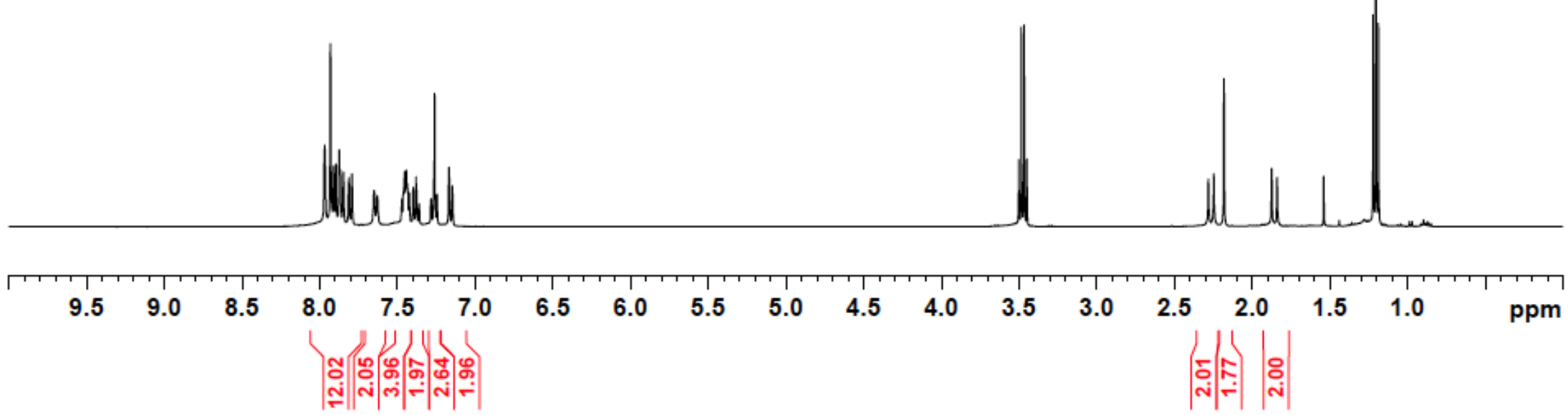



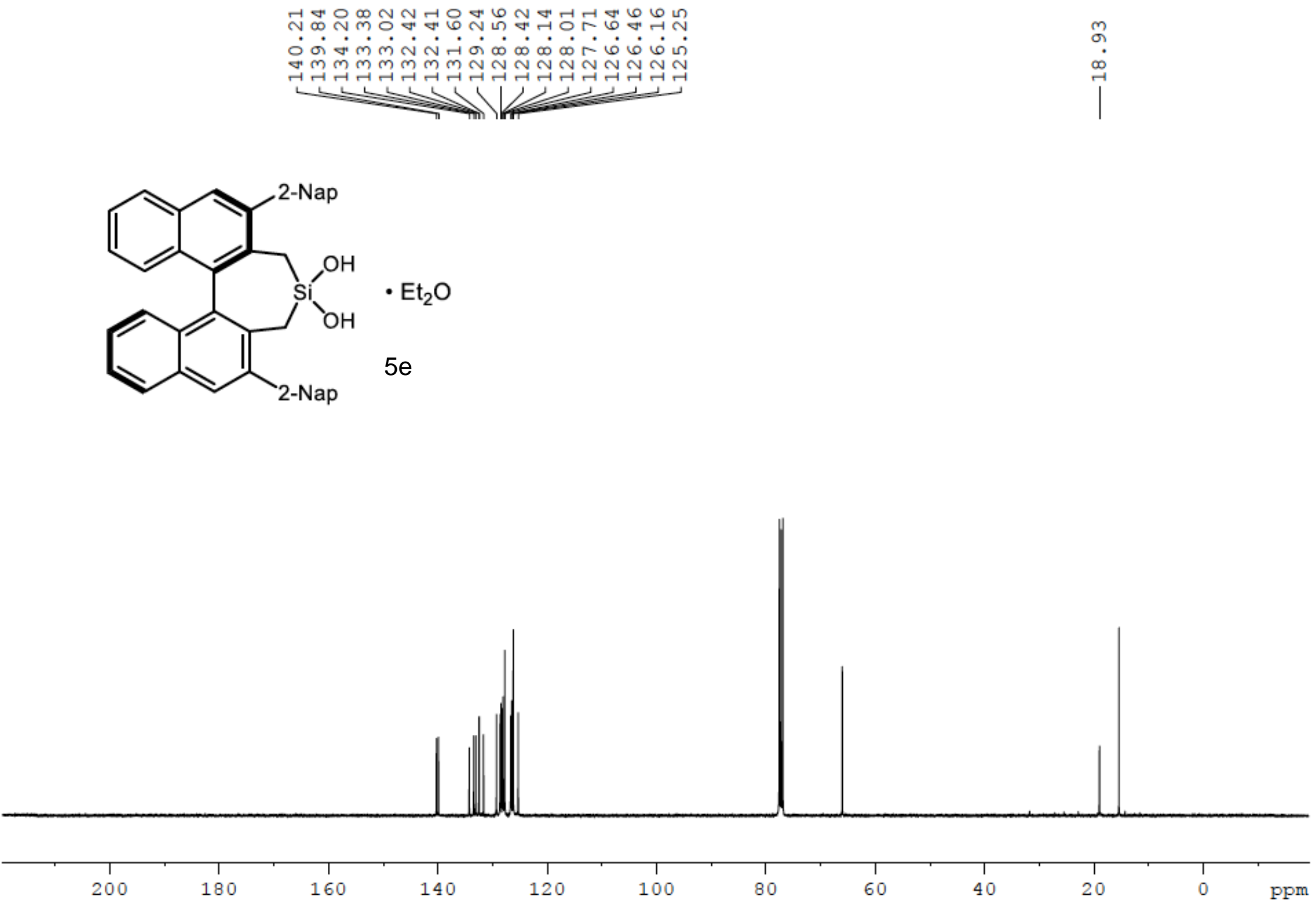


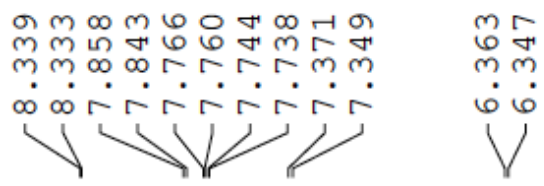<smiles>O=c1ccoc2ccc(Br)cc12</smiles>

$1 c$

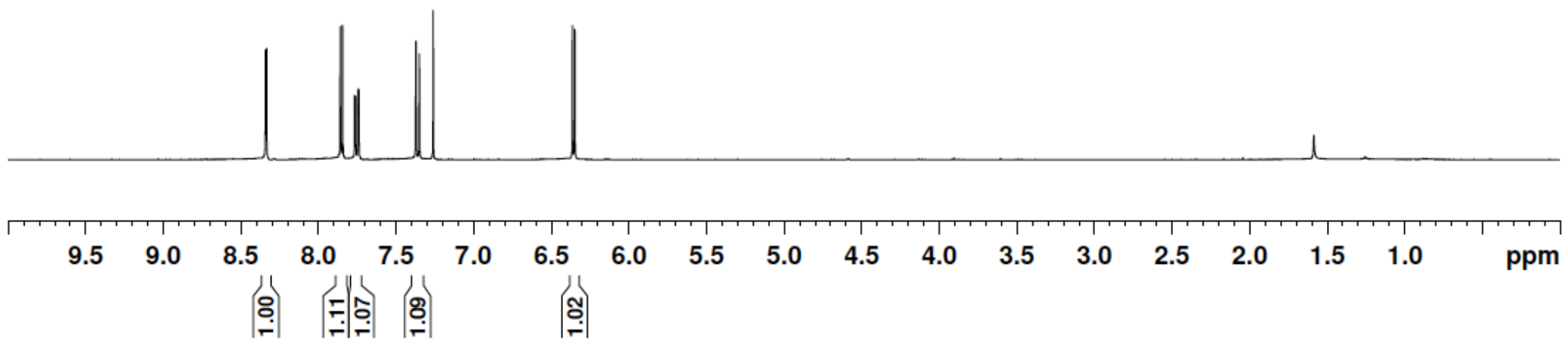




|<smiles>O=c1ccoc2ccc(Br)cc12</smiles>

$1 \mathrm{c}$

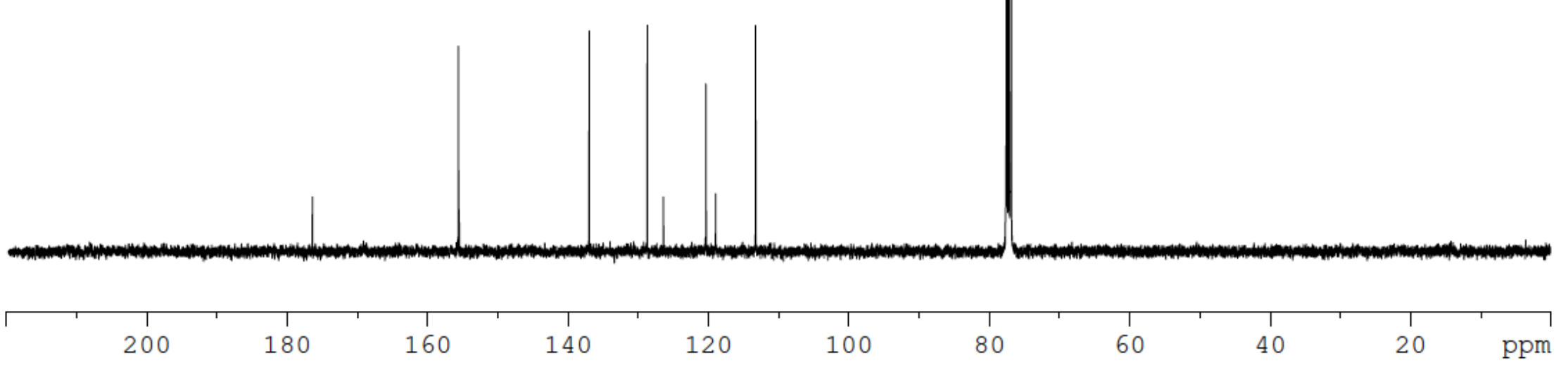




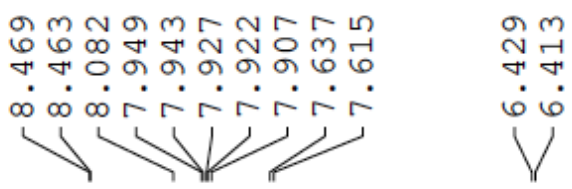<smiles>O=c1ccoc2ccc(-c3cc(C(F)(F)F)cc(C(F)(F)F)c3)cc12</smiles>

$1 d$

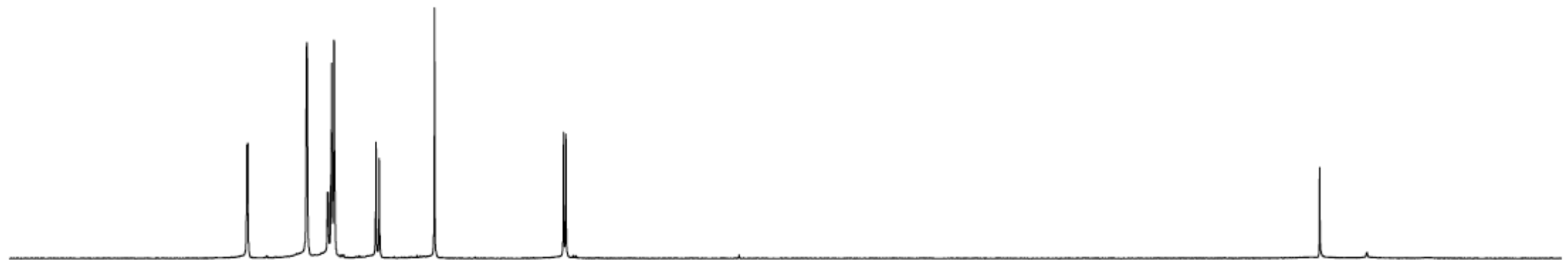

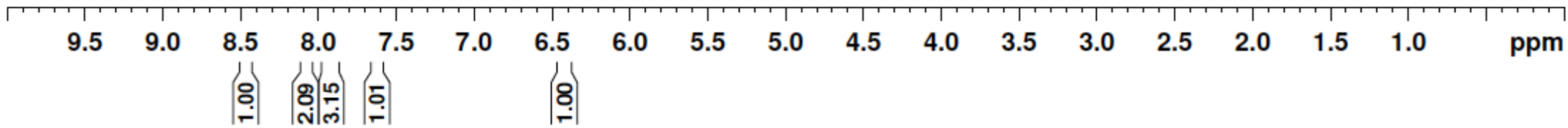


房

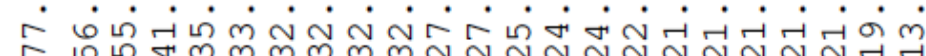

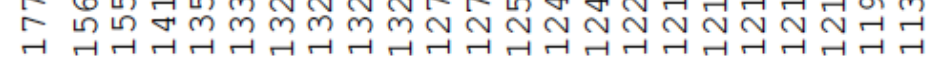

(n)<smiles>O=c1ccoc2ccc(-c3cc(C(F)(F)F)cc(C(F)(F)F)c3)cc12</smiles>

1d

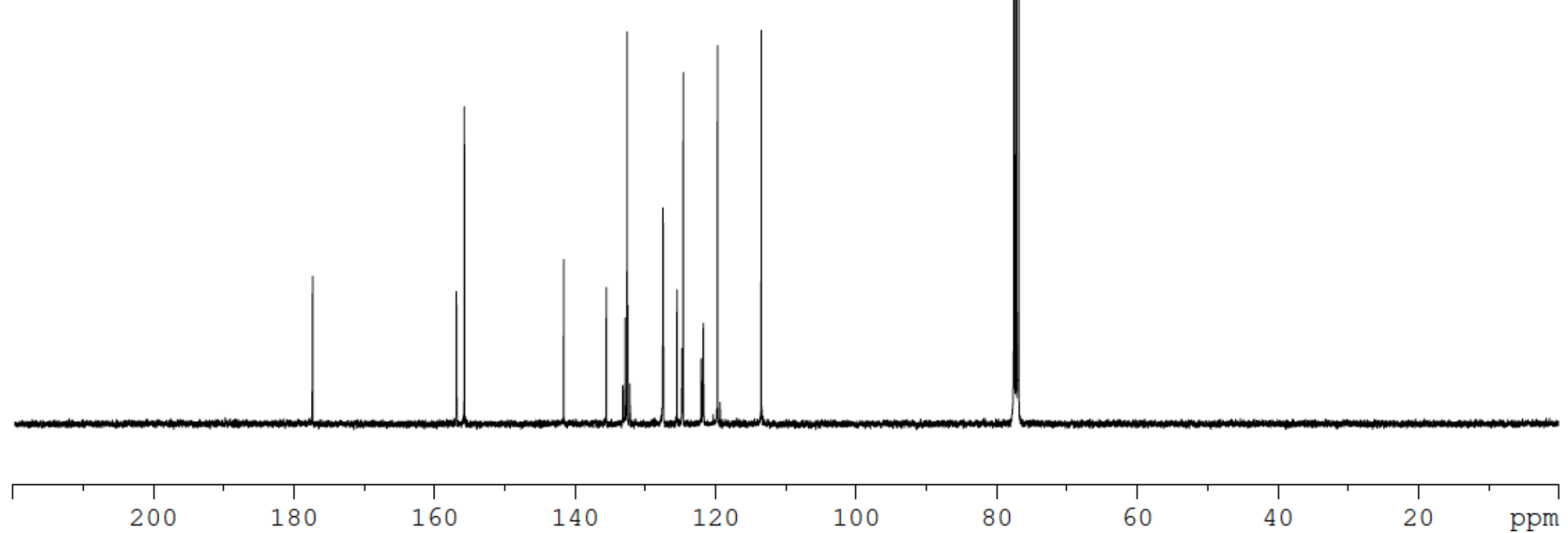




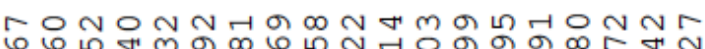

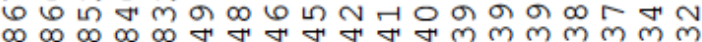

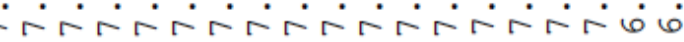
$\longrightarrow$<smiles>O=c1ccoc2ccc(F)cc12</smiles>

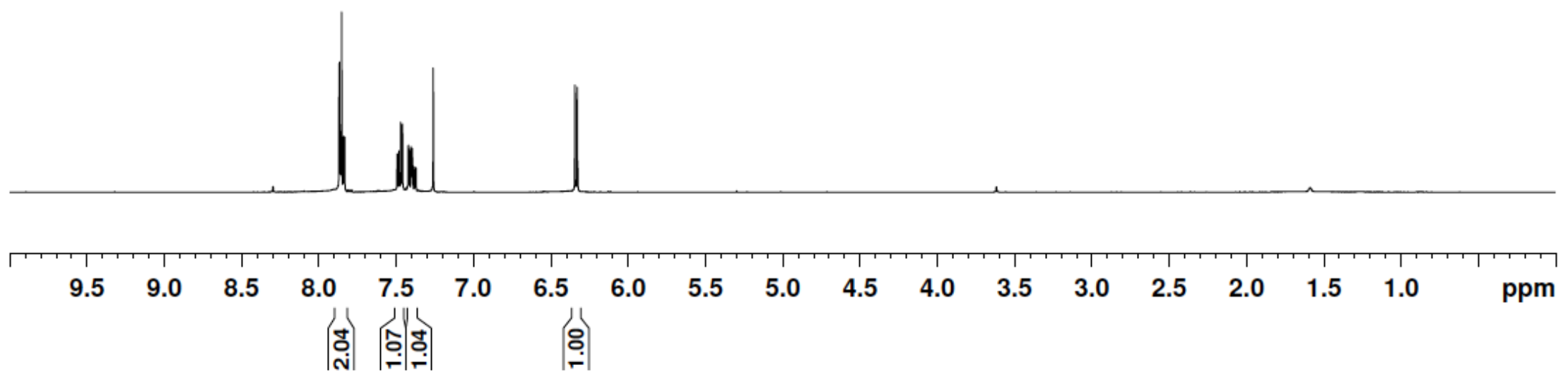



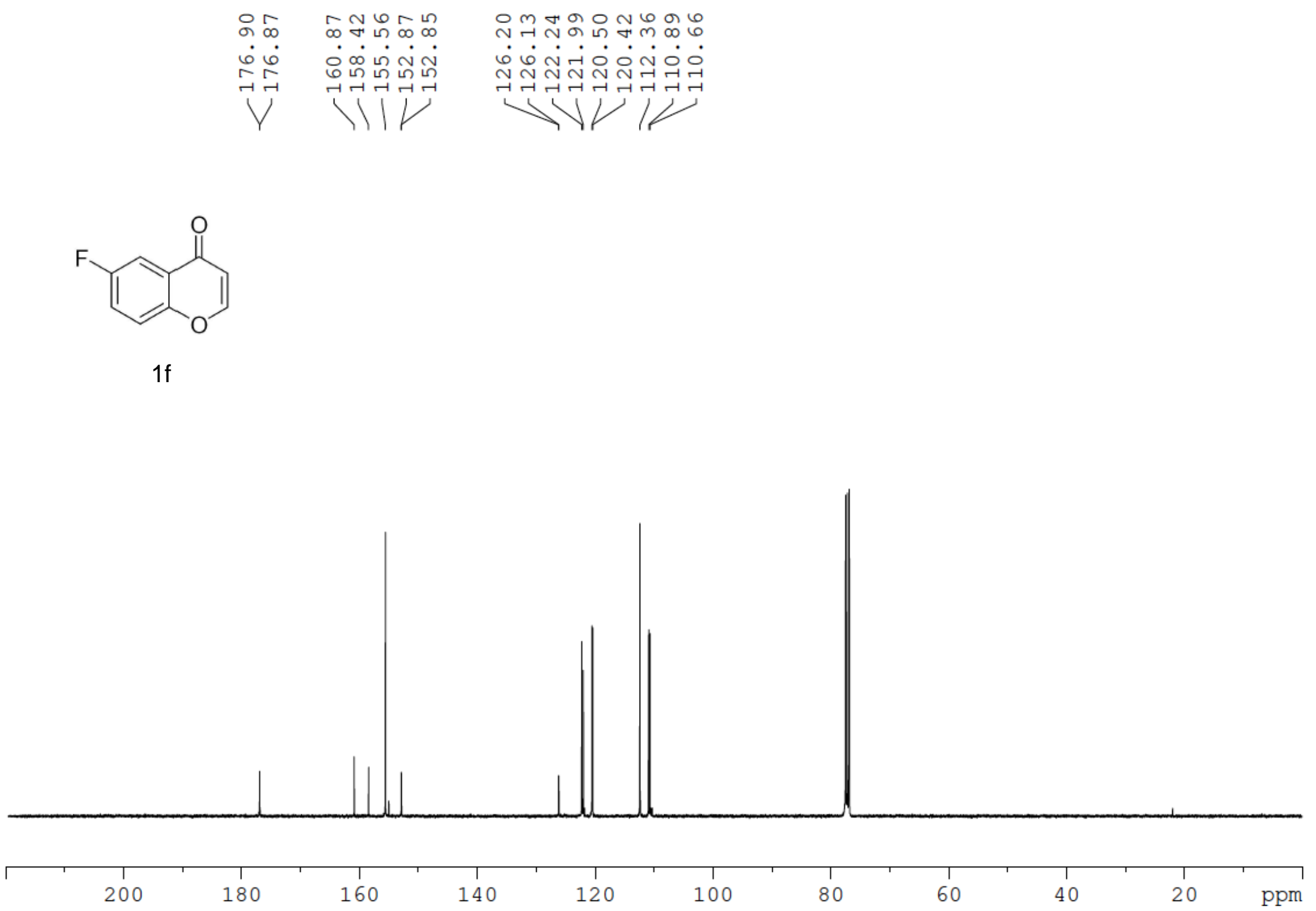


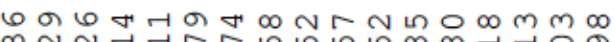

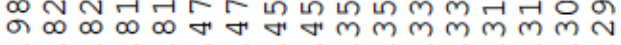

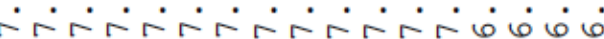

$\ldots$<smiles>Cc1ccc2occc(=O)c2c1</smiles>

$1 \mathrm{~g}$
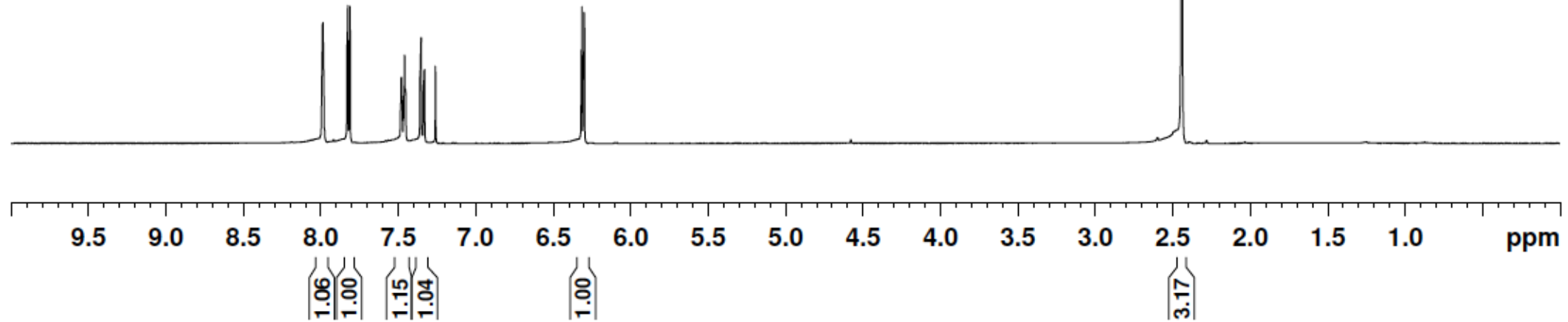


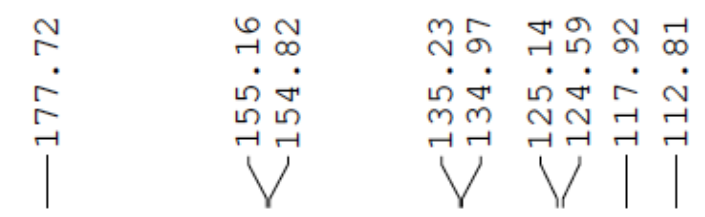

नु

우

I<smiles>Cc1ccc2occc(=O)c2c1</smiles>

$1 \mathrm{~g}$

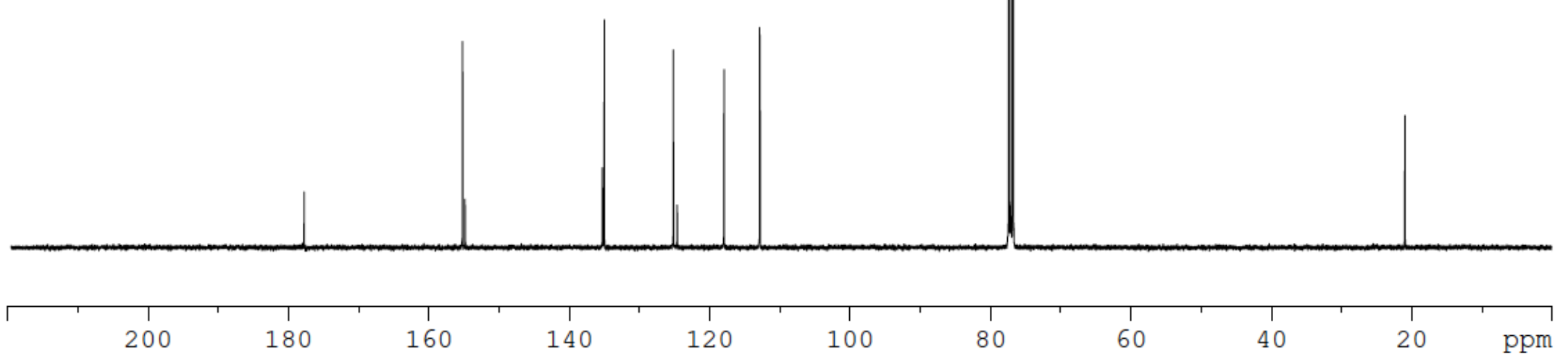



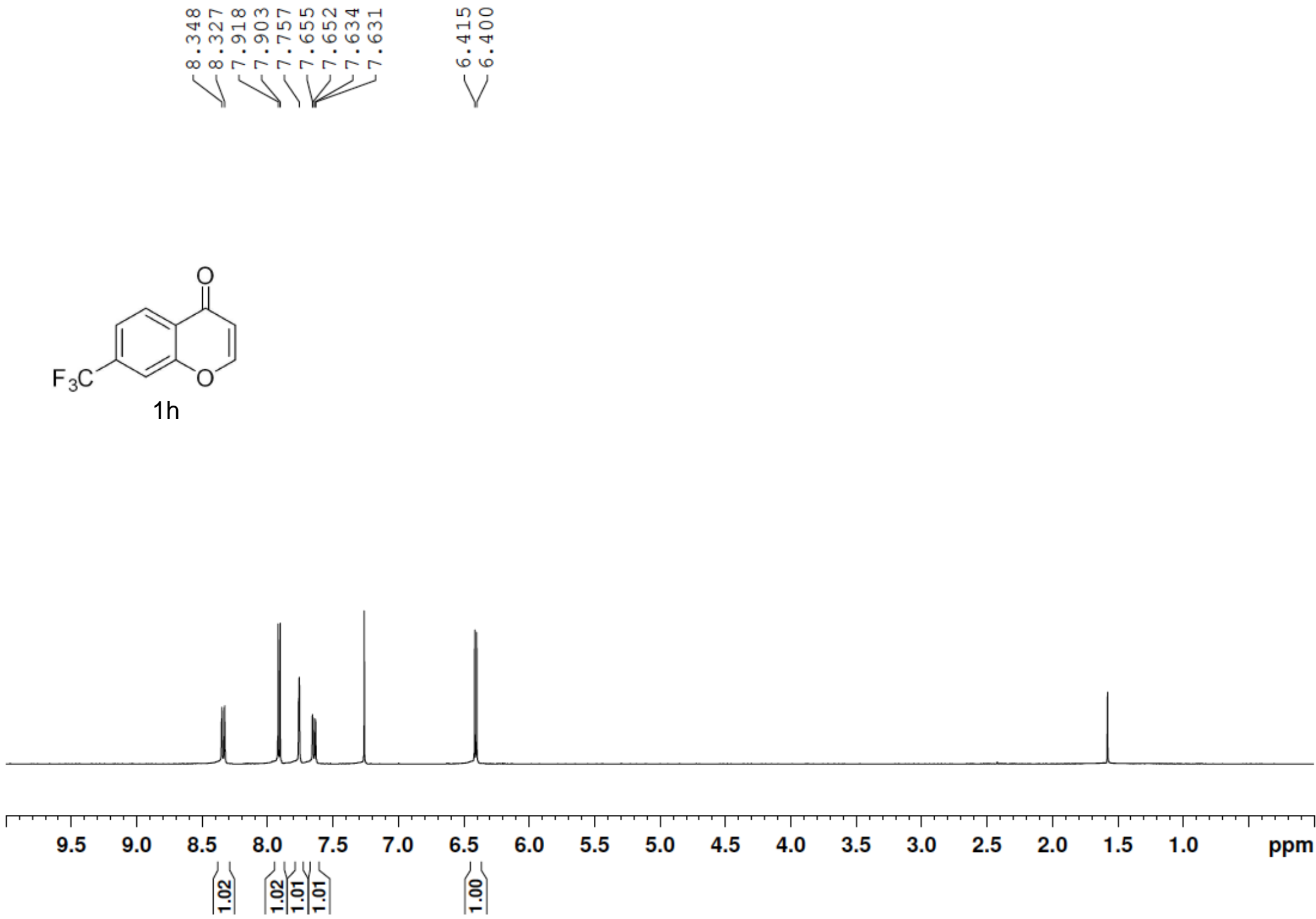

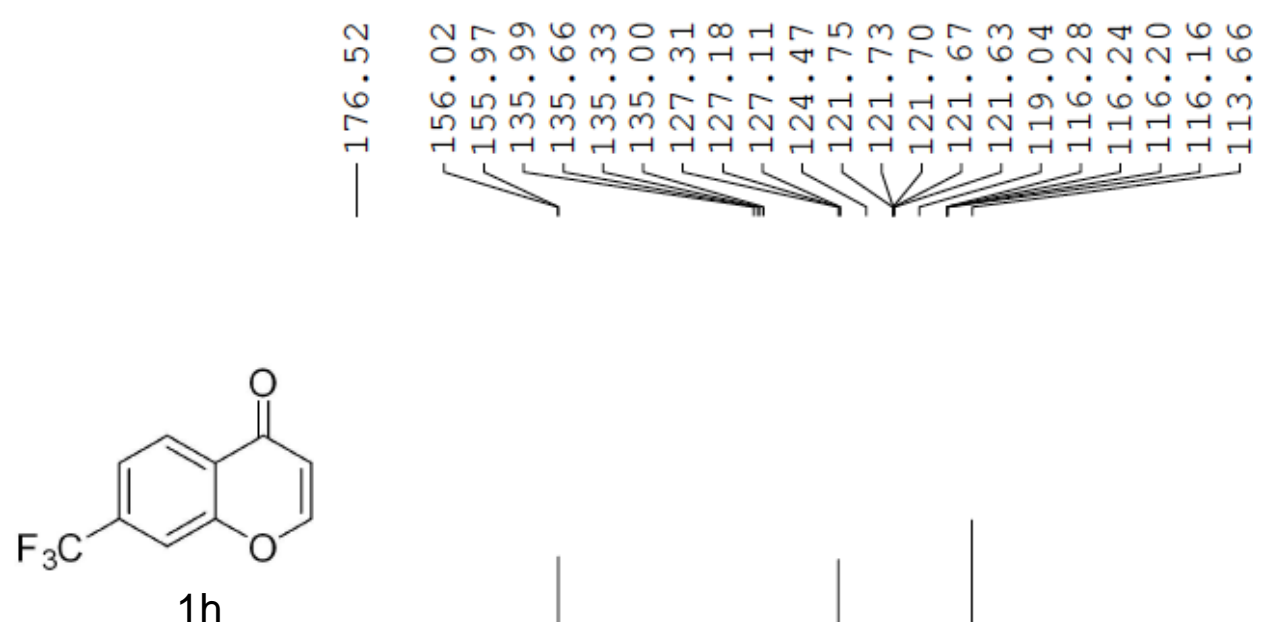

$1 \mathrm{~h}$
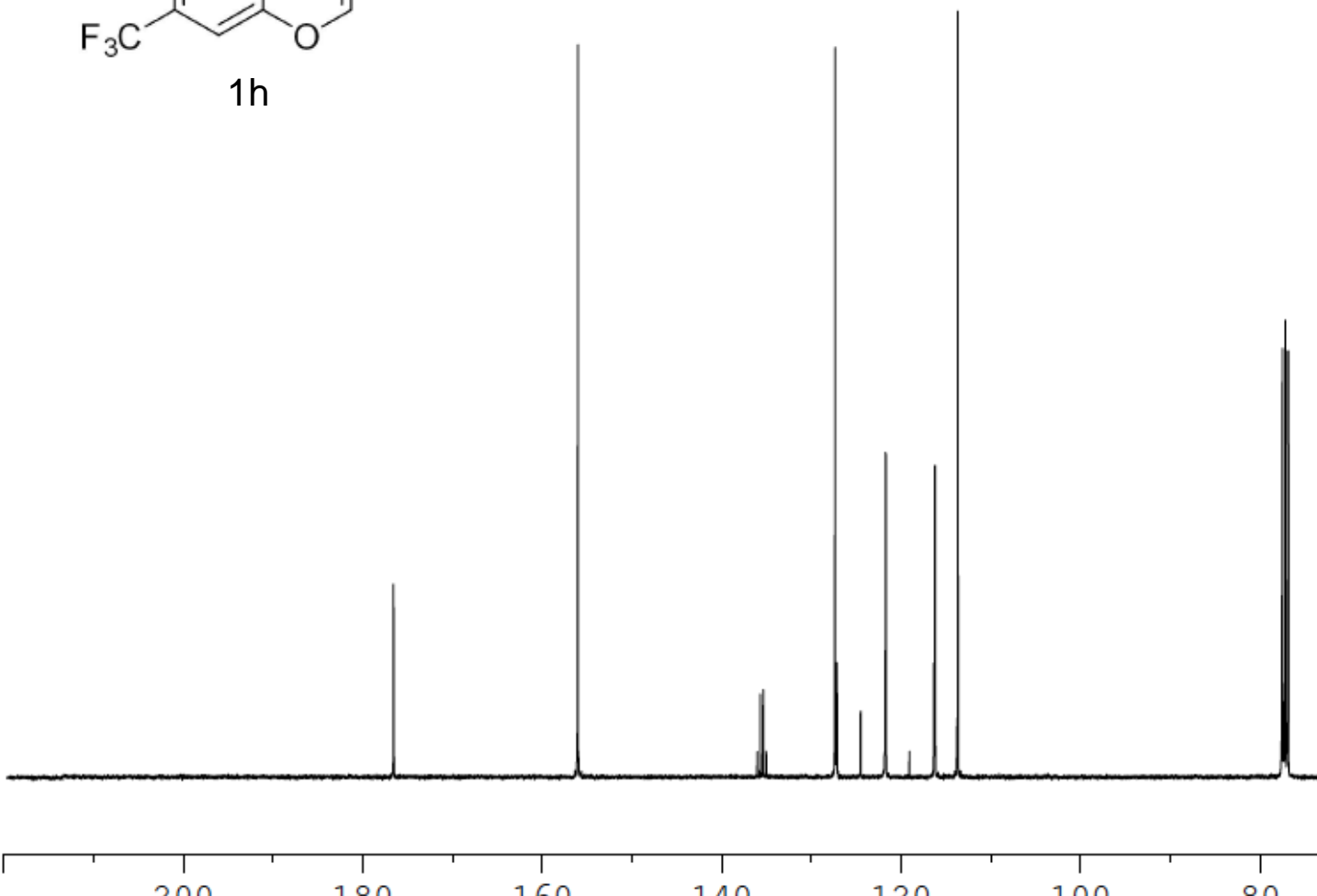

200
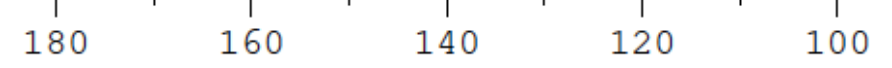

80

60

40

20 
응유

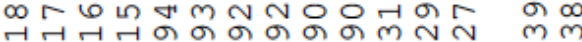

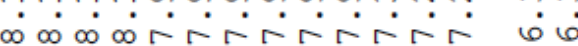
$\underbrace{\infty} \underbrace{\infty}$<smiles>O=c1ccoc2c(Br)cccc12</smiles>
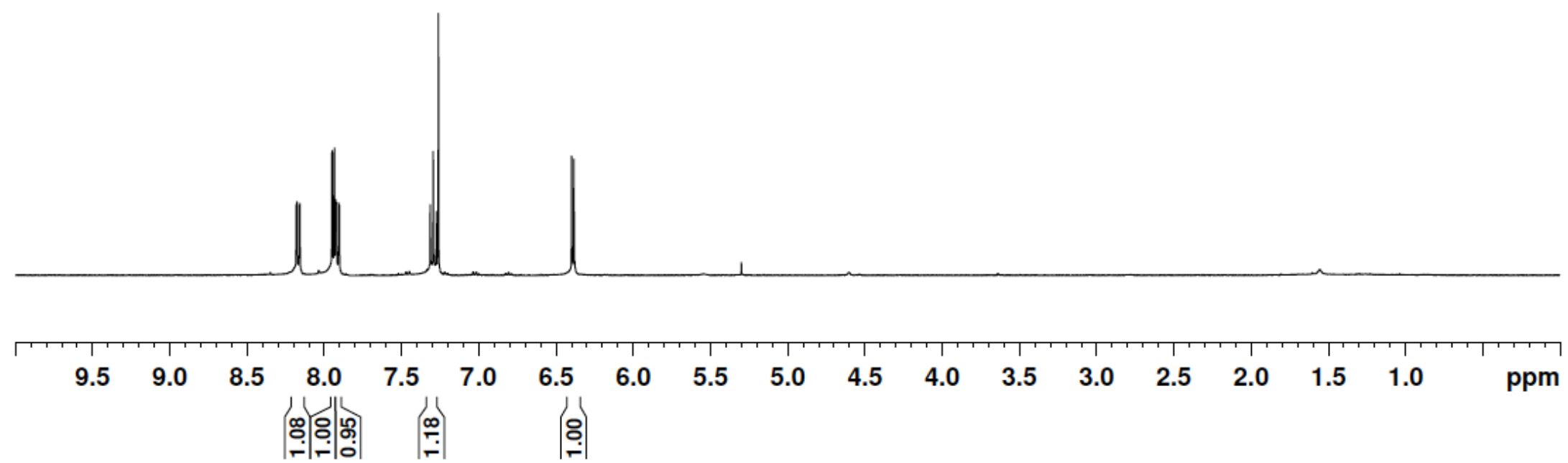


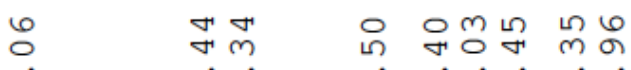

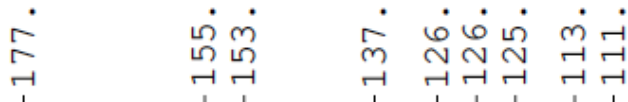

$$
\begin{aligned}
& \text { l I I I I }
\end{aligned}
$$
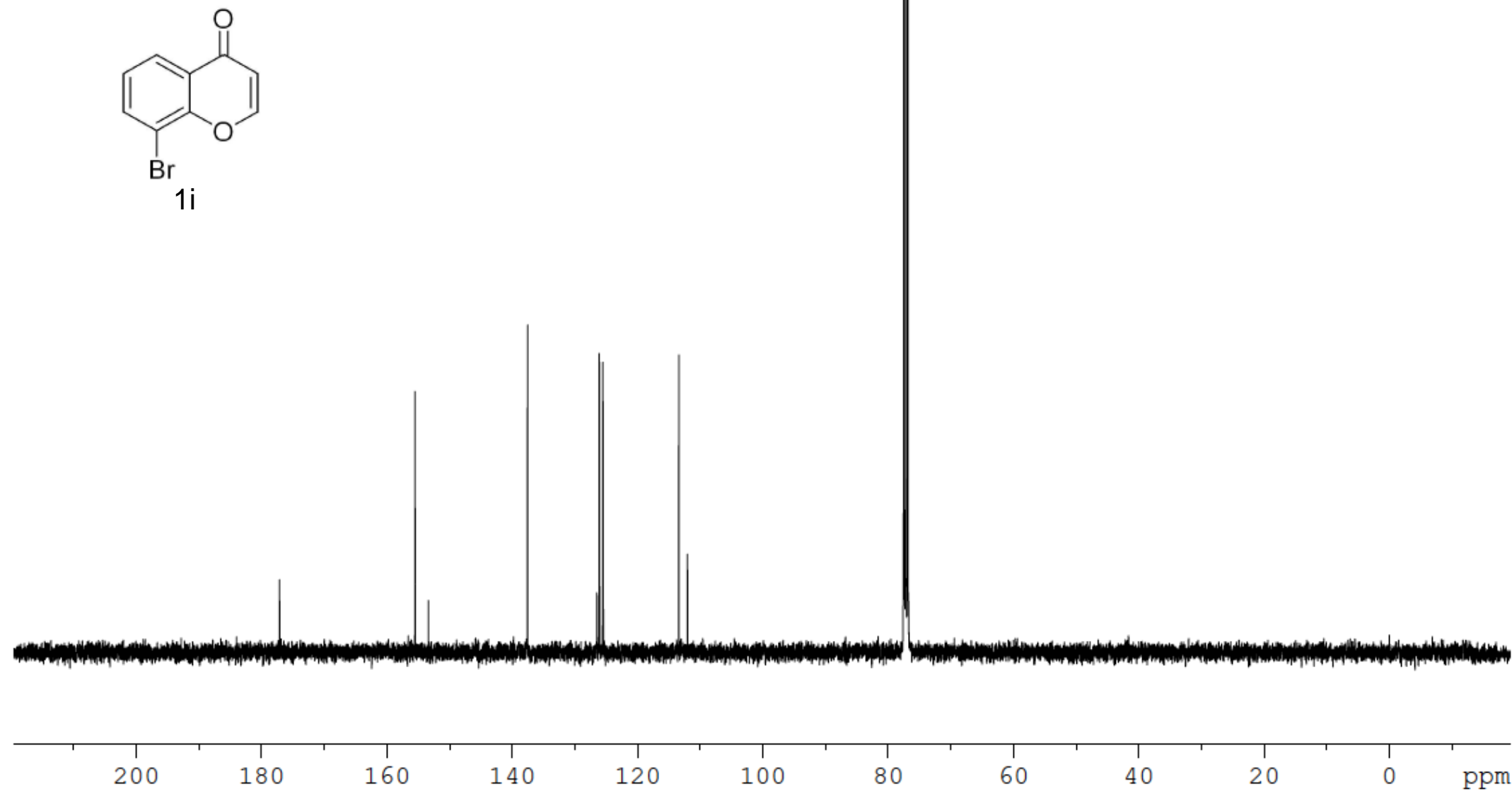


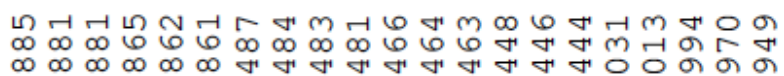

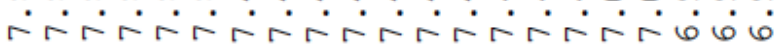

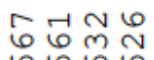

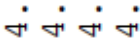
$\longrightarrow$

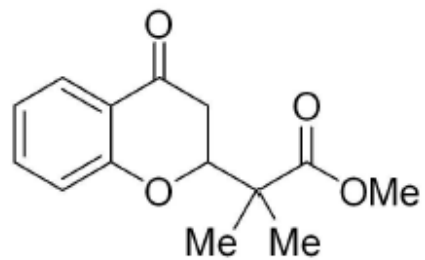

$4 a$
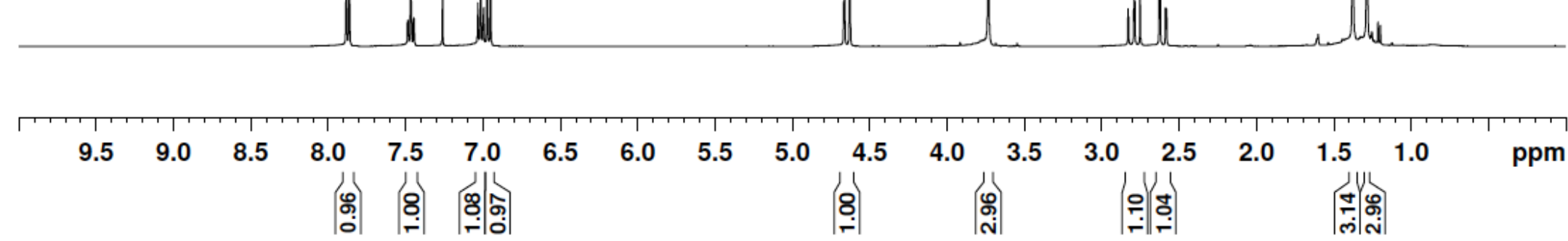


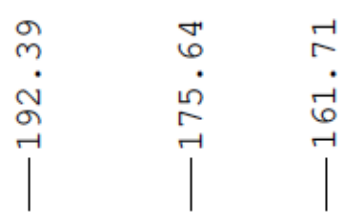

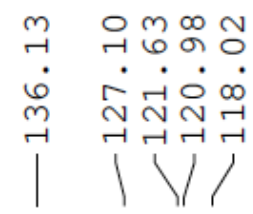

$\stackrel{\llcorner}{\infty}$

-

$\infty$

$m$ n

$\dot{v} \dot{\omega} \infty$

in

$\stackrel{m \infty}{n}$

$\circ \dot{0}$

v

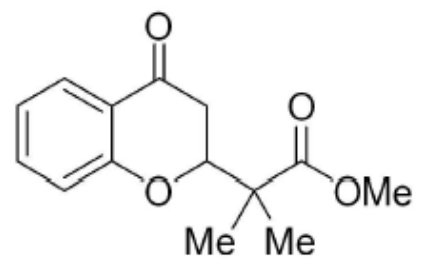

$4 a$

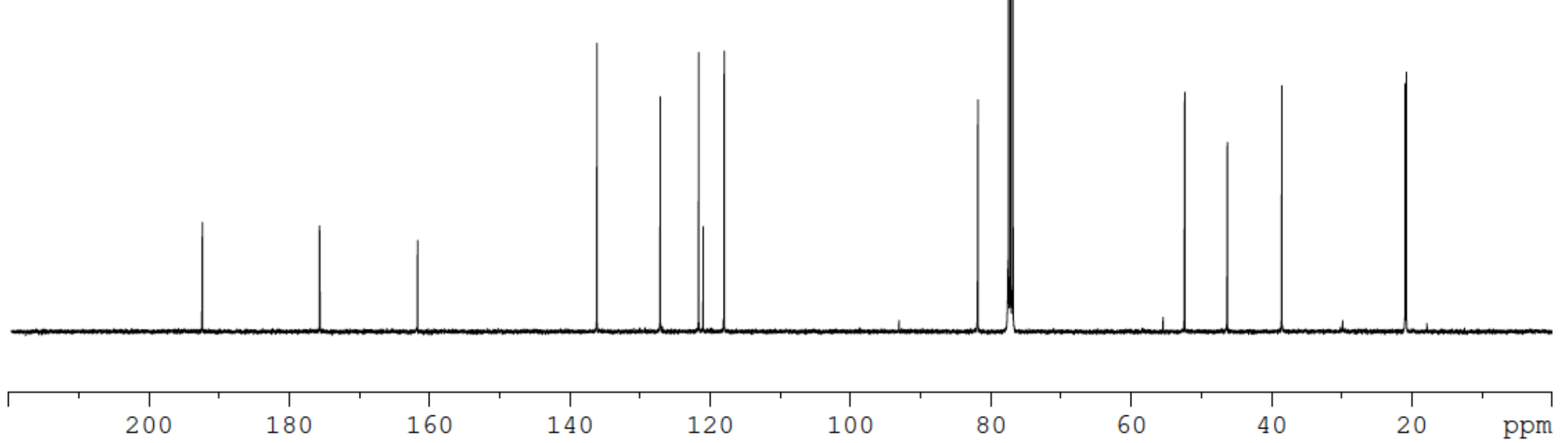


전은

ल N

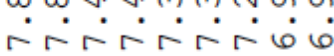

4

กู่

ب.

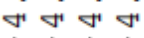

4

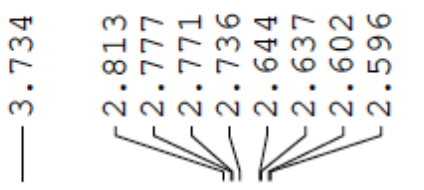

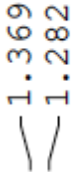

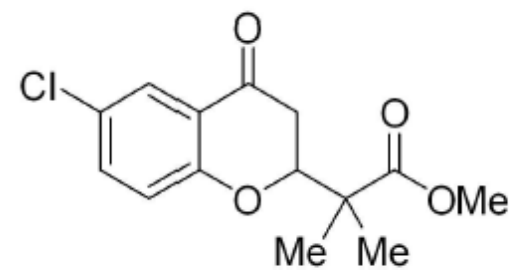

$4 b$
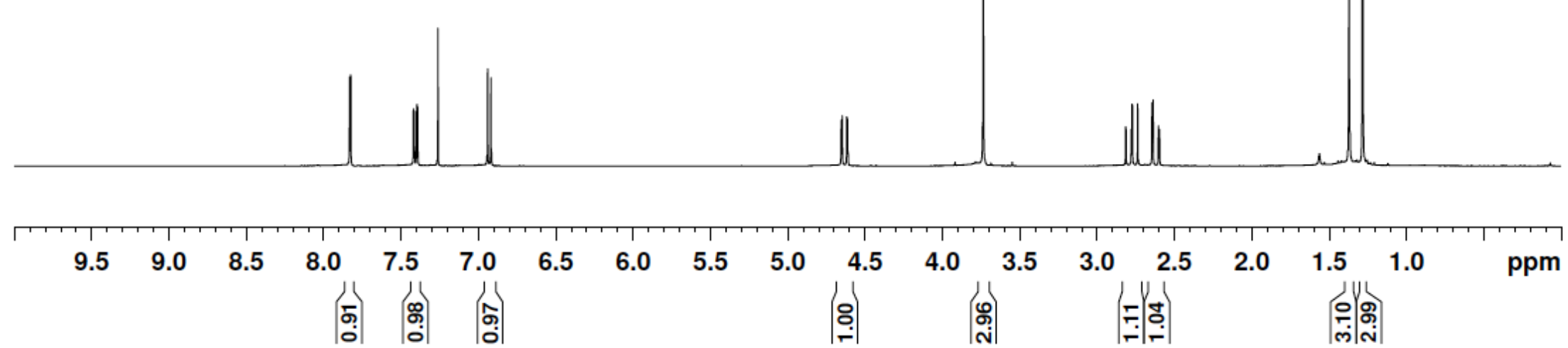


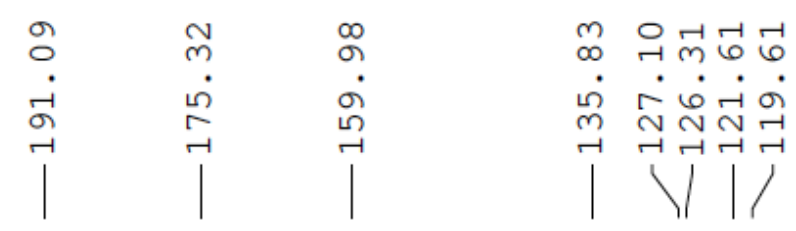

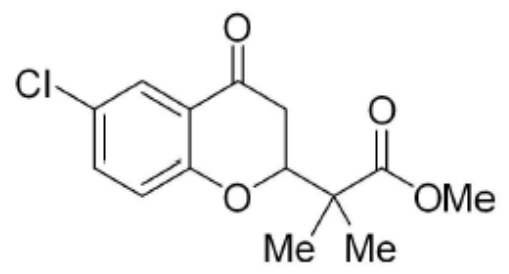

$4 \mathrm{~b}$

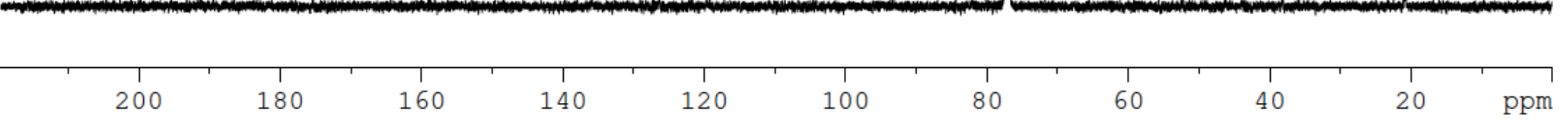




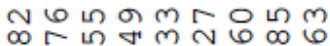

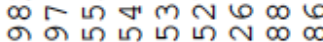

rararario

i
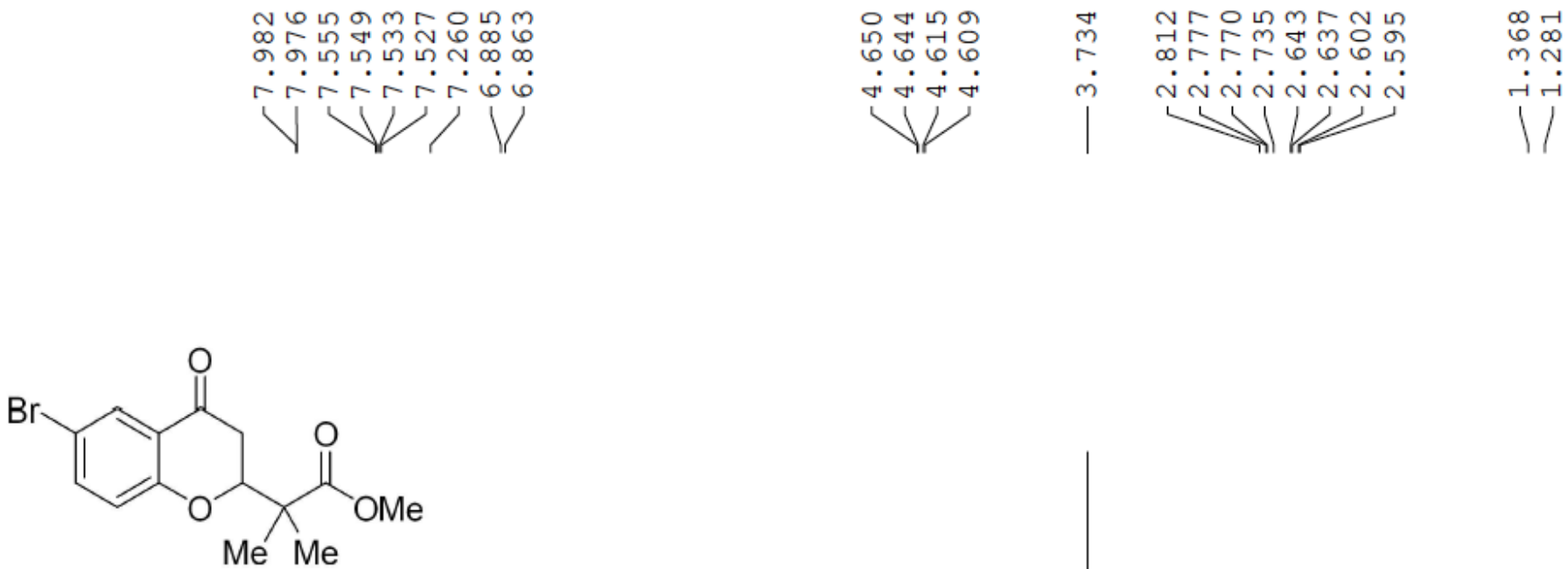

$4 c$

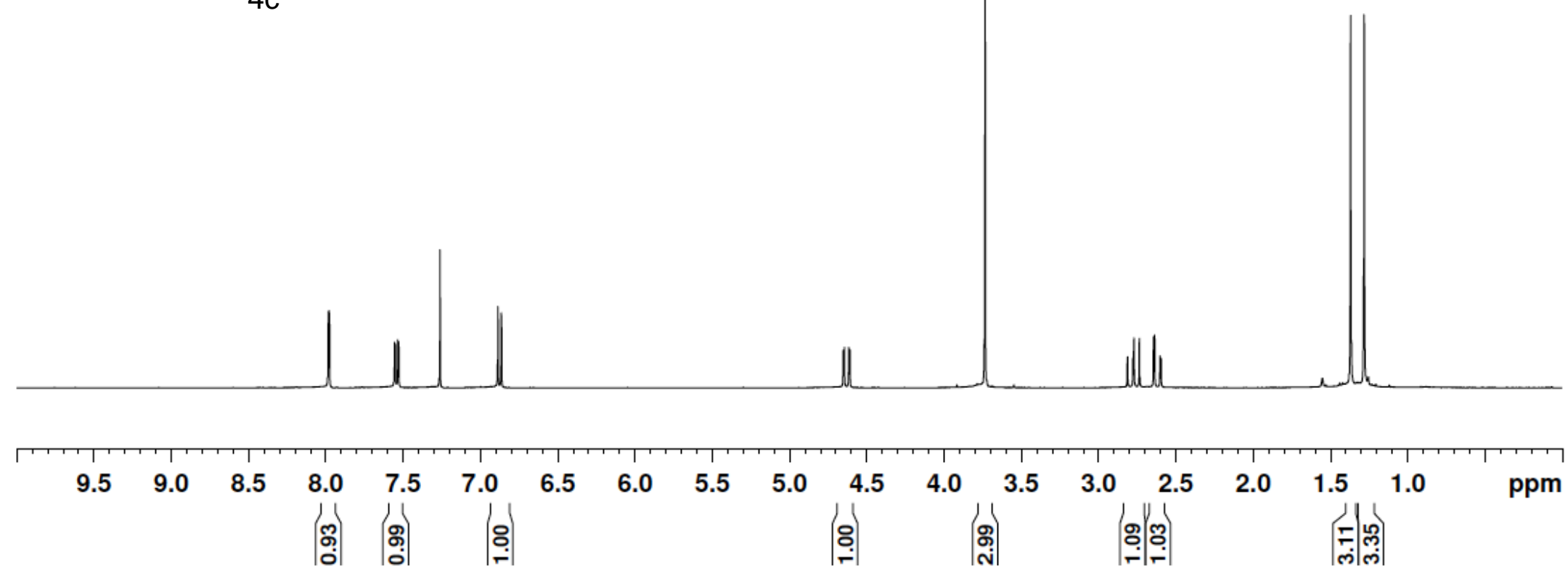




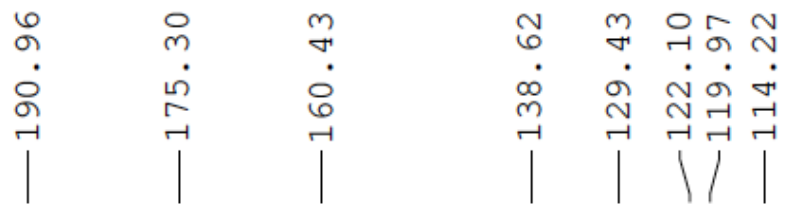

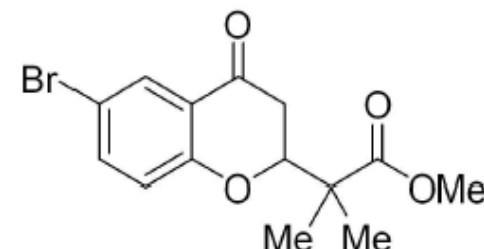

$4 c$

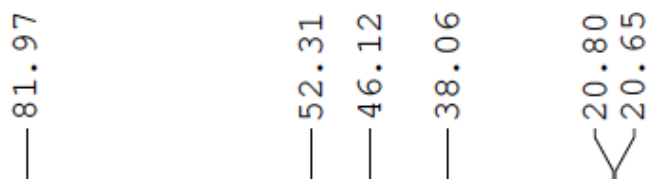

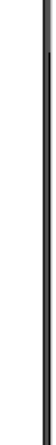

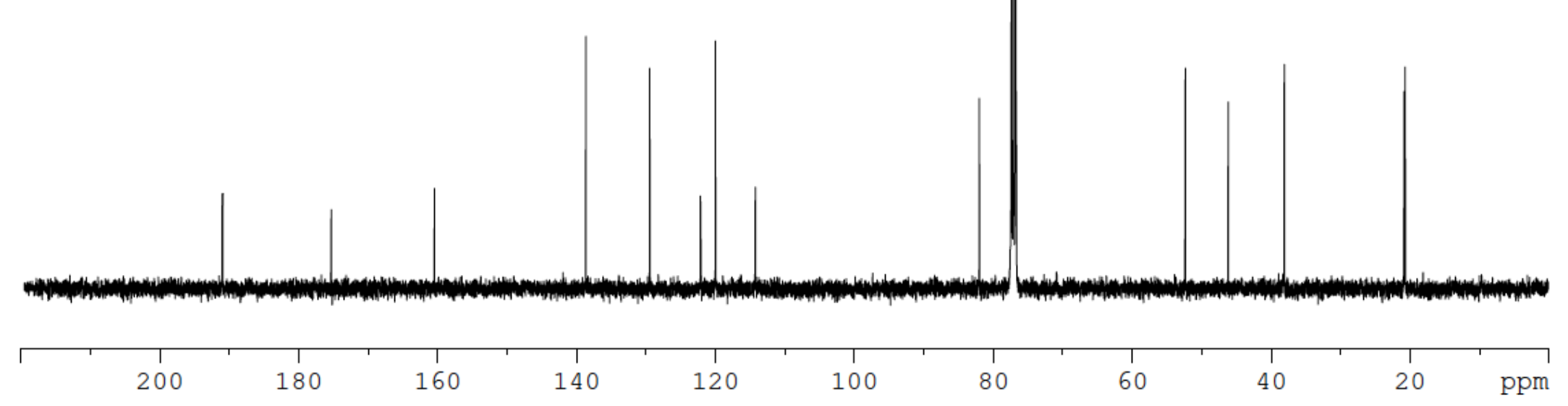



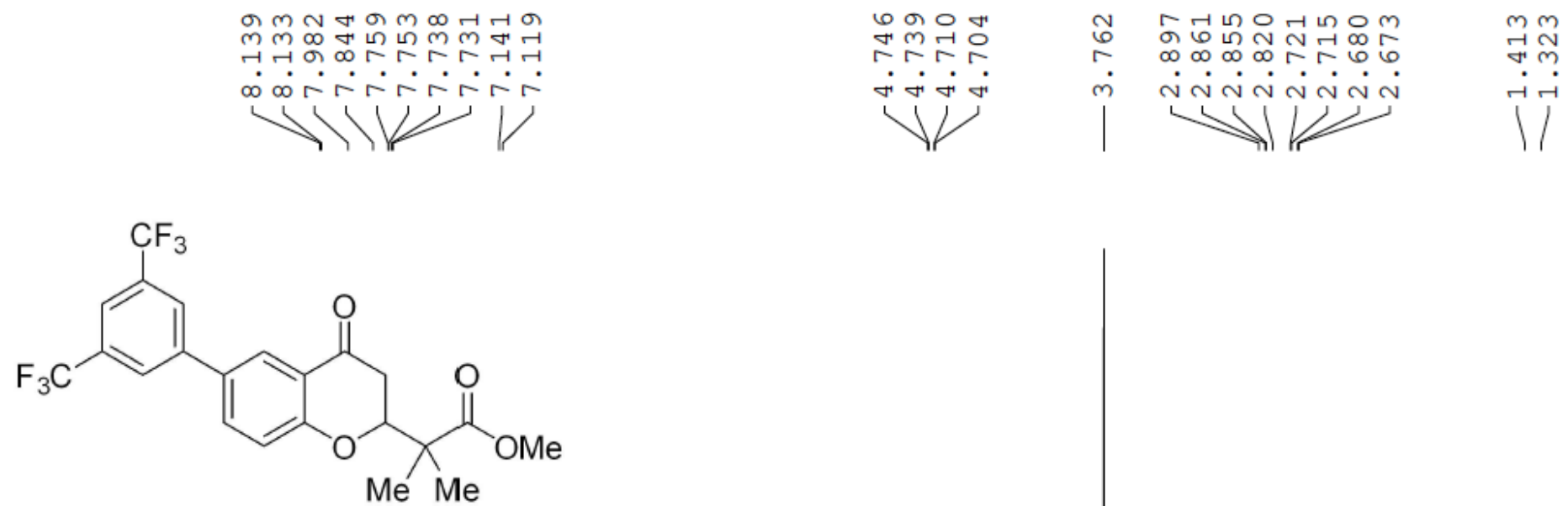

$4 d$
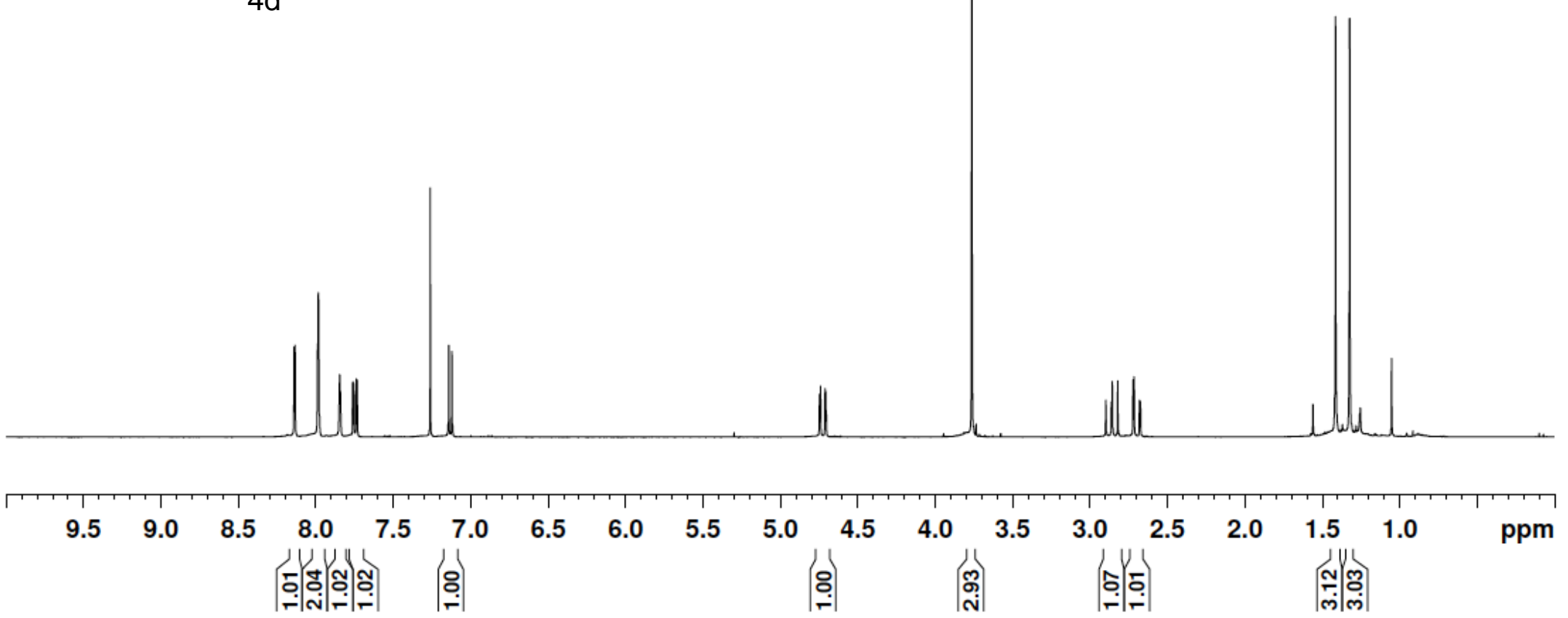

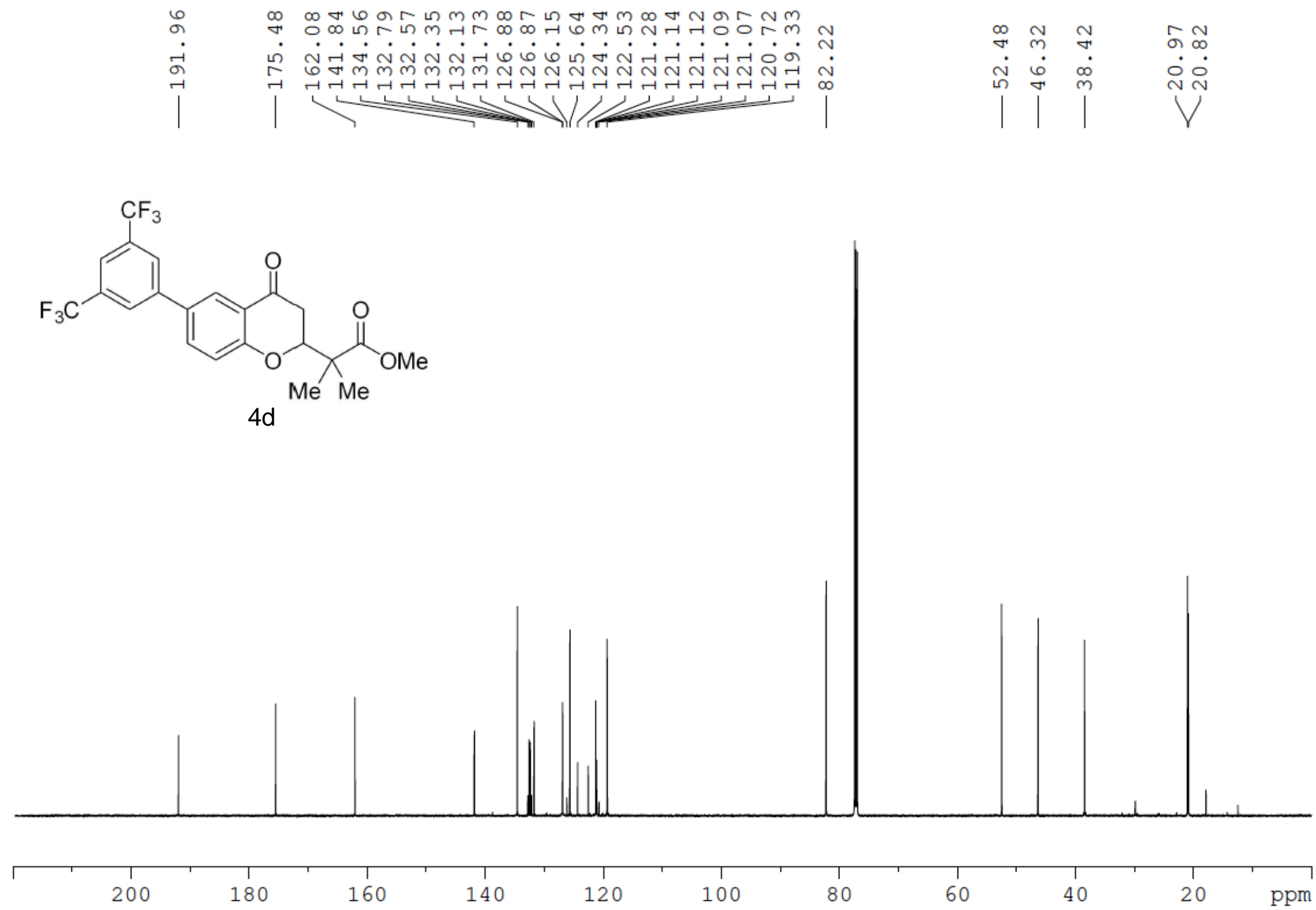

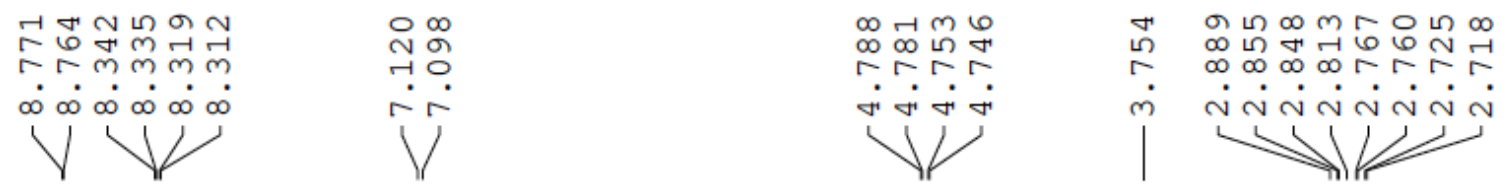

|

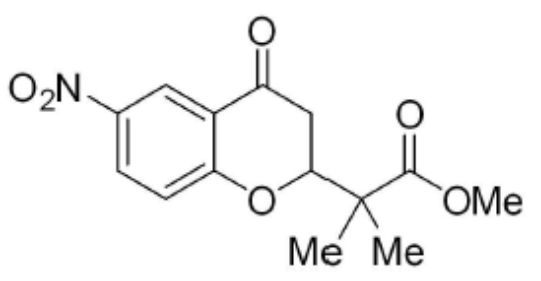

$4 e$
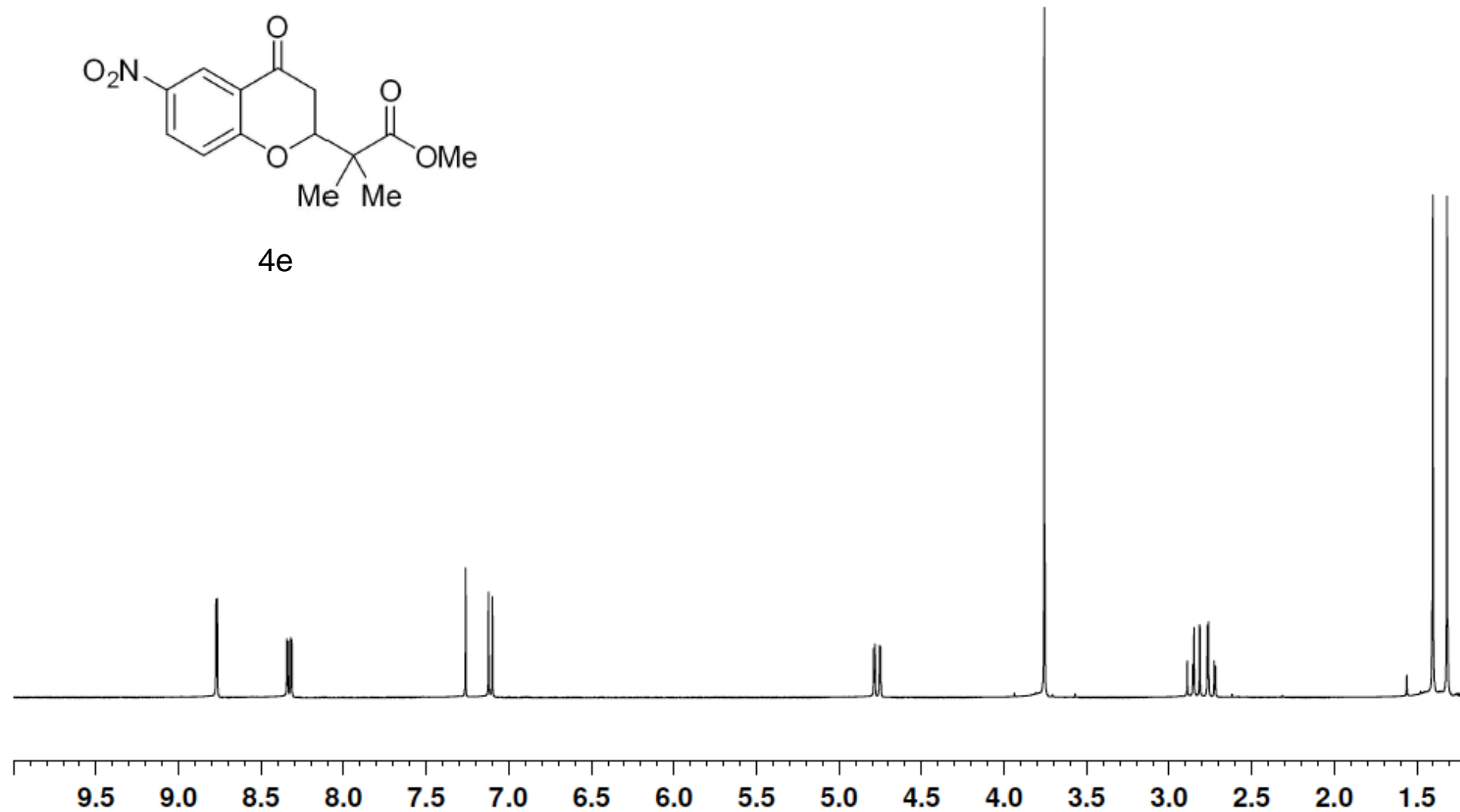

9.5
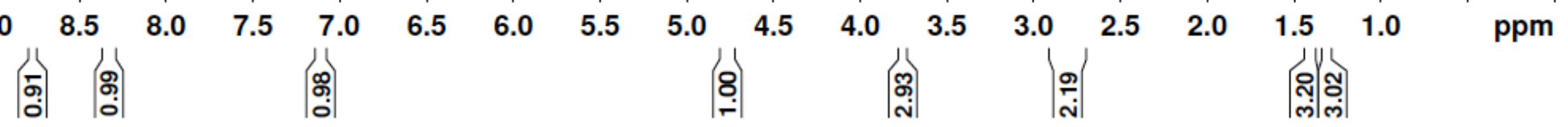

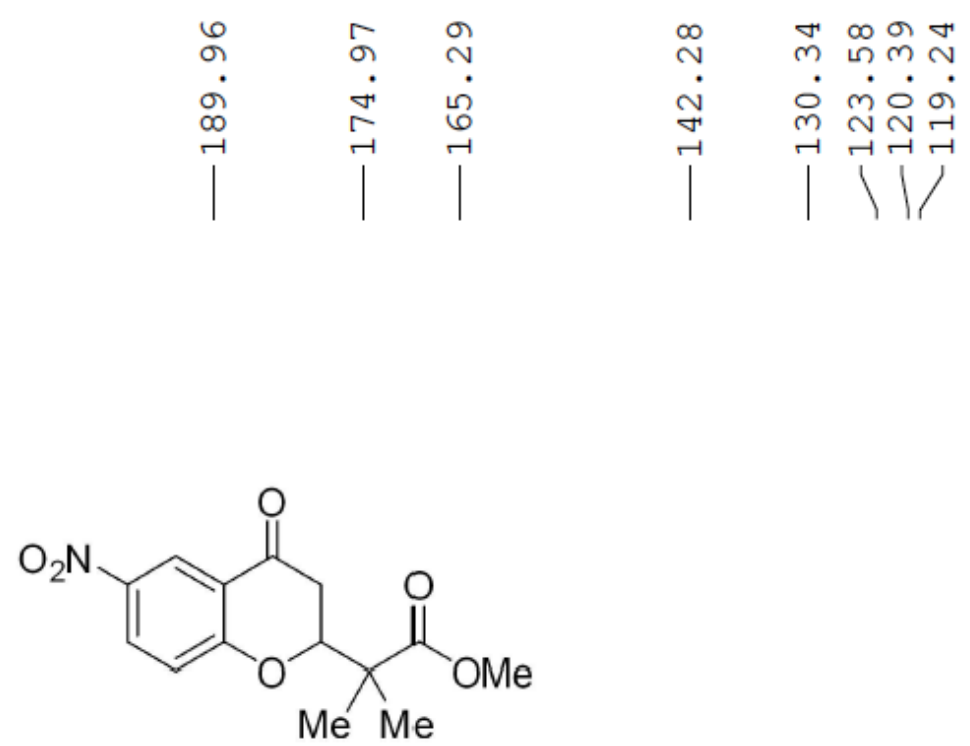

$\infty$
6
$\dot{N}$
$\infty$
$\mid$

마 न

î

$\prod_{\infty}^{\infty} \underset{6}{\infty}$

$4 \mathrm{e}$

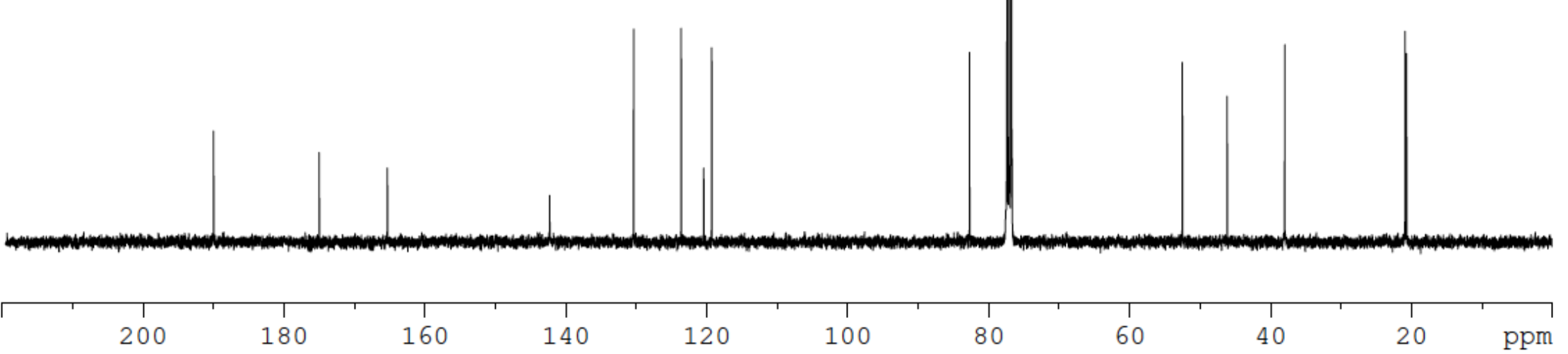



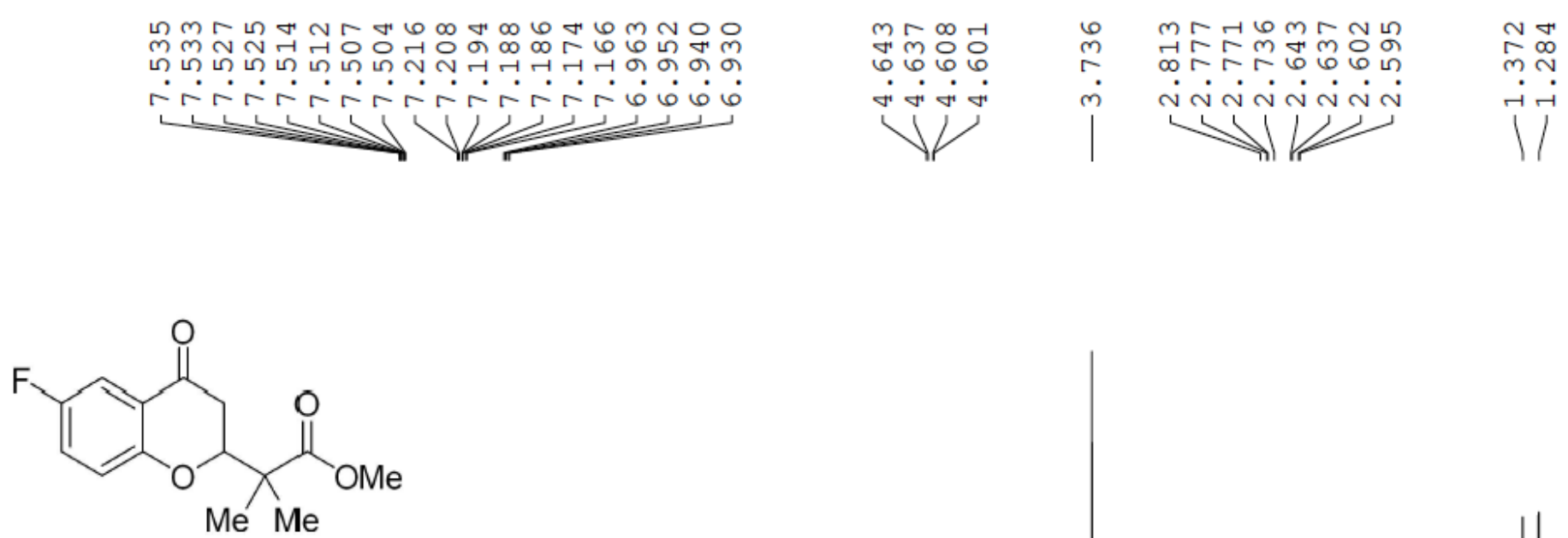

$4 f$
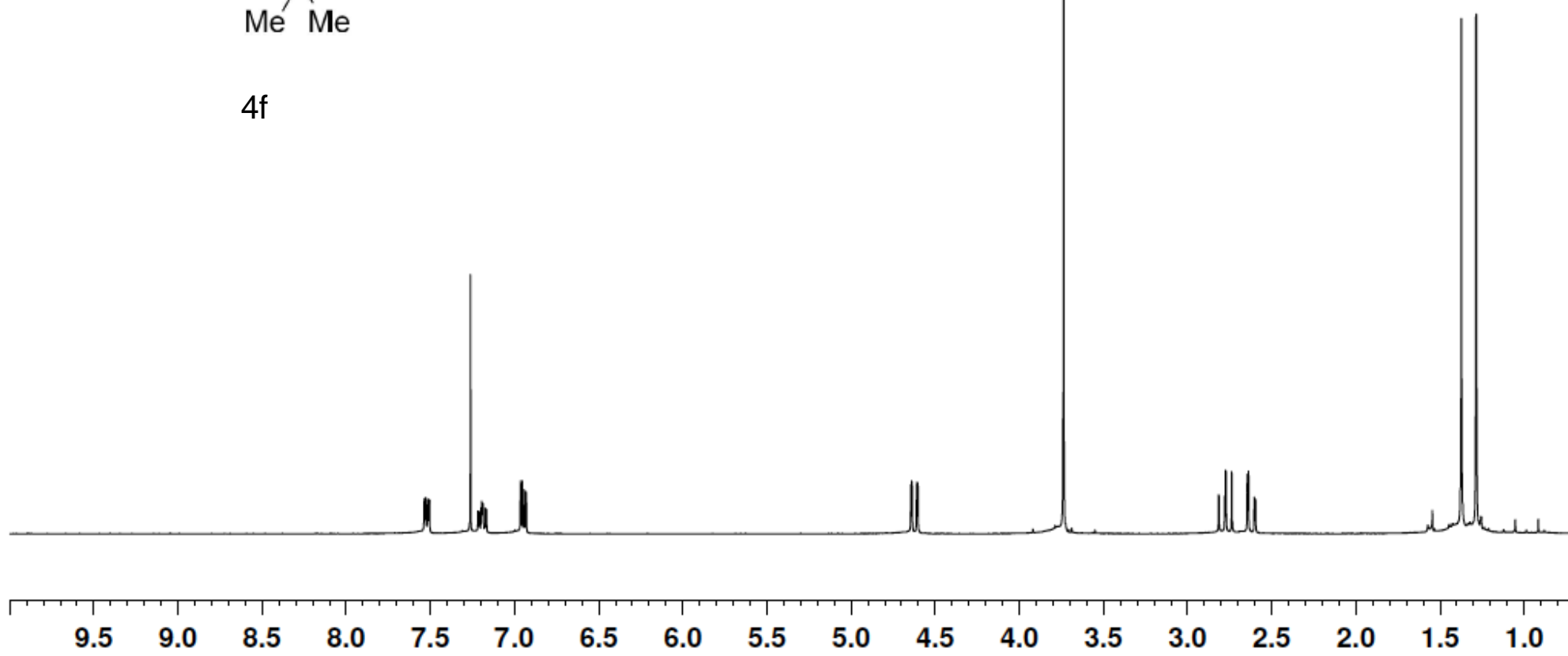

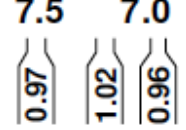
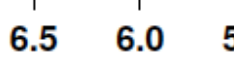

$5.5 \quad 5.0$

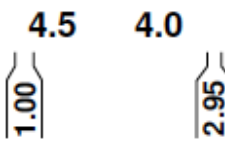

$\begin{array}{ll}3.5 & 3.0\end{array}$

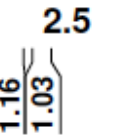

2.0

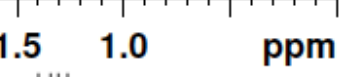




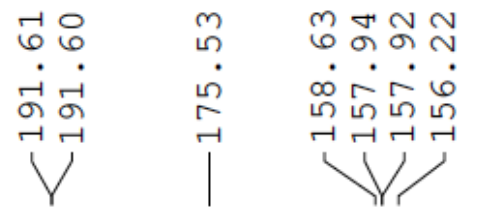

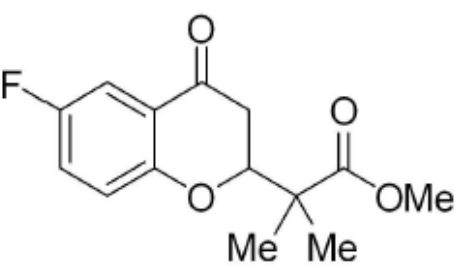

$4 f$

\section{(n)}

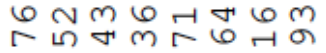

लंलंनंबंबंत्र

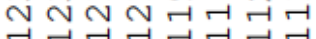

N1

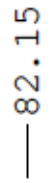

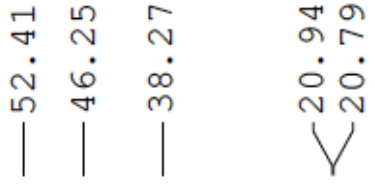

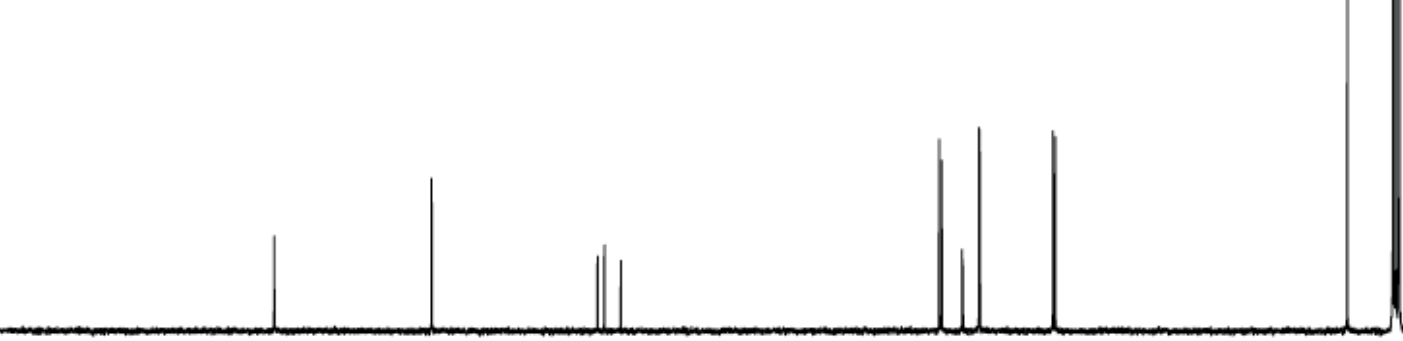
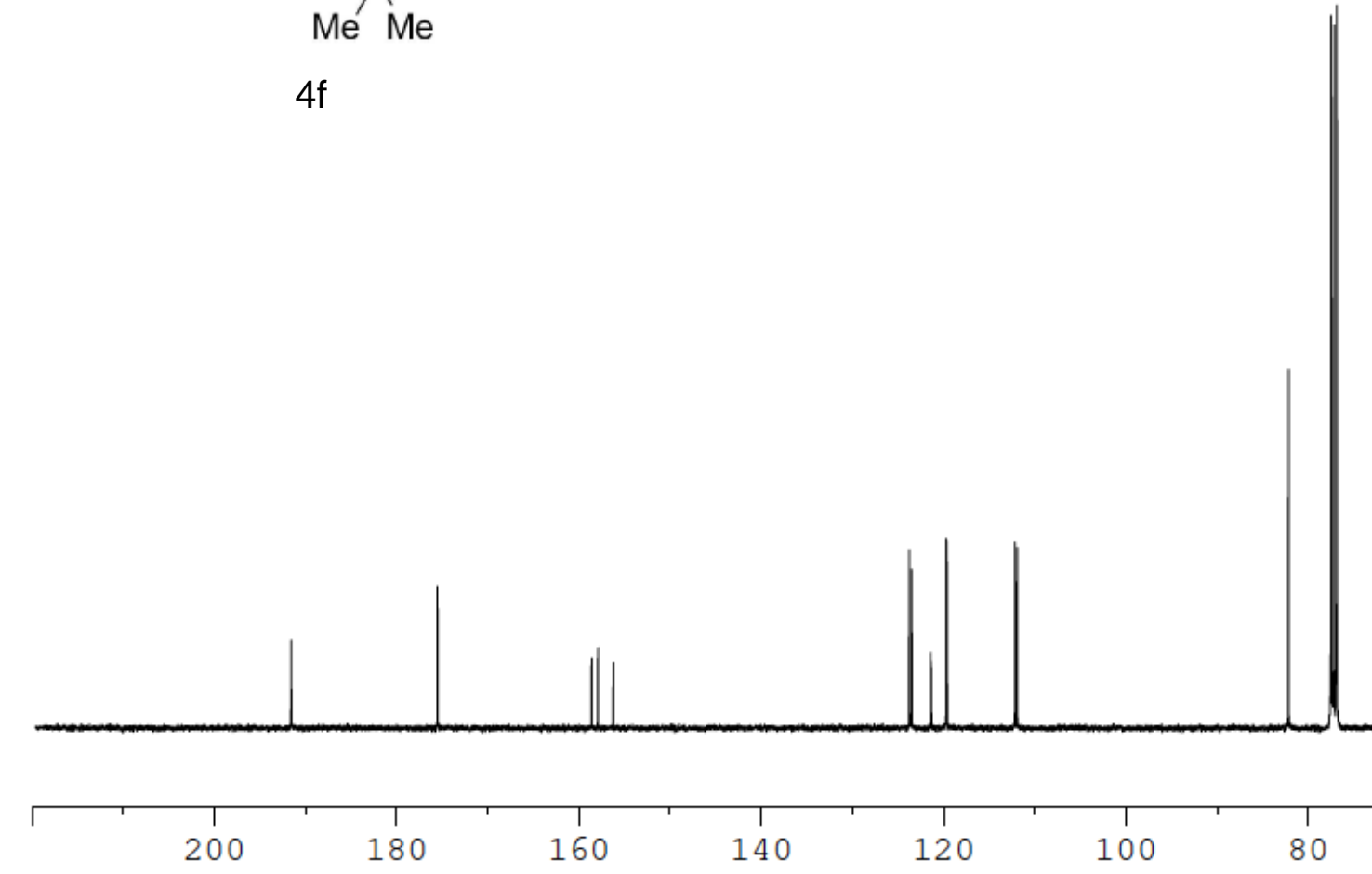

180

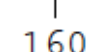

140

120

100

80

60

40

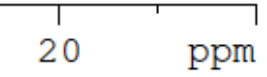


vin

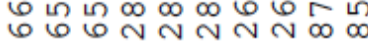

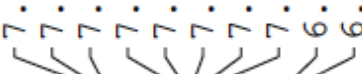

$m \Gamma \infty N$

ำ

$\cdot$.

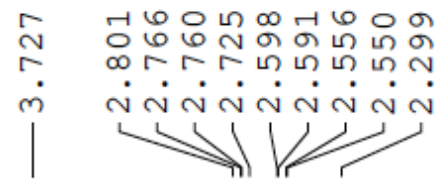

농

$\sqrt{4}$

m.

I

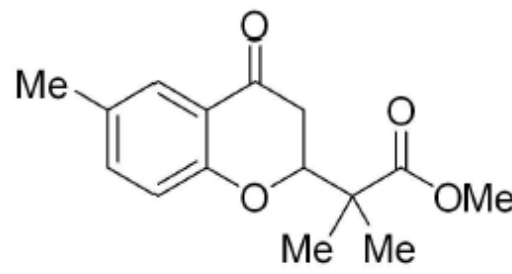

$4 \mathrm{~g}$
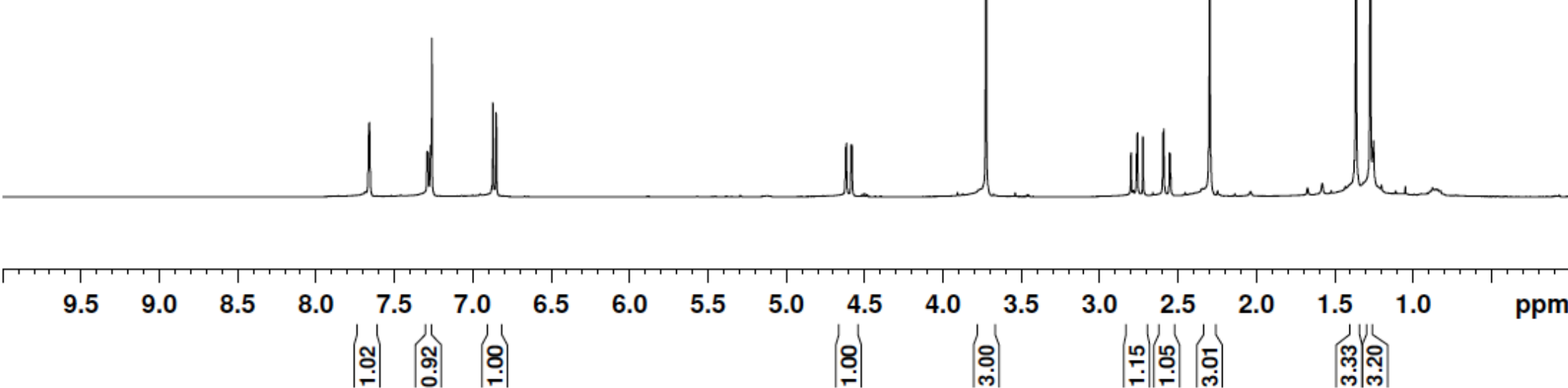


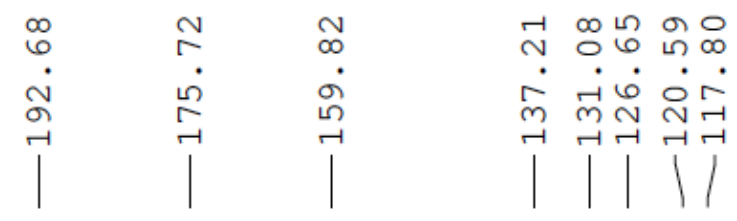

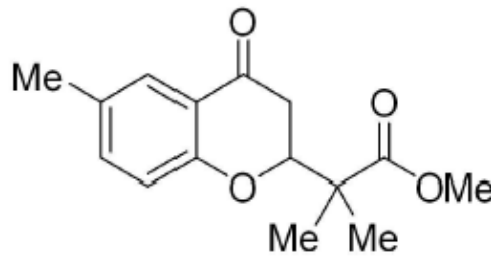

$4 g$

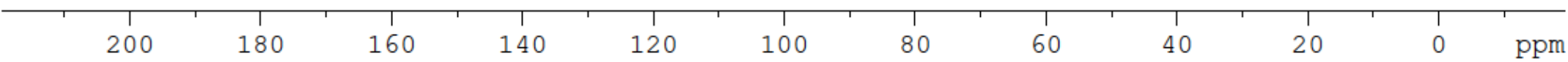



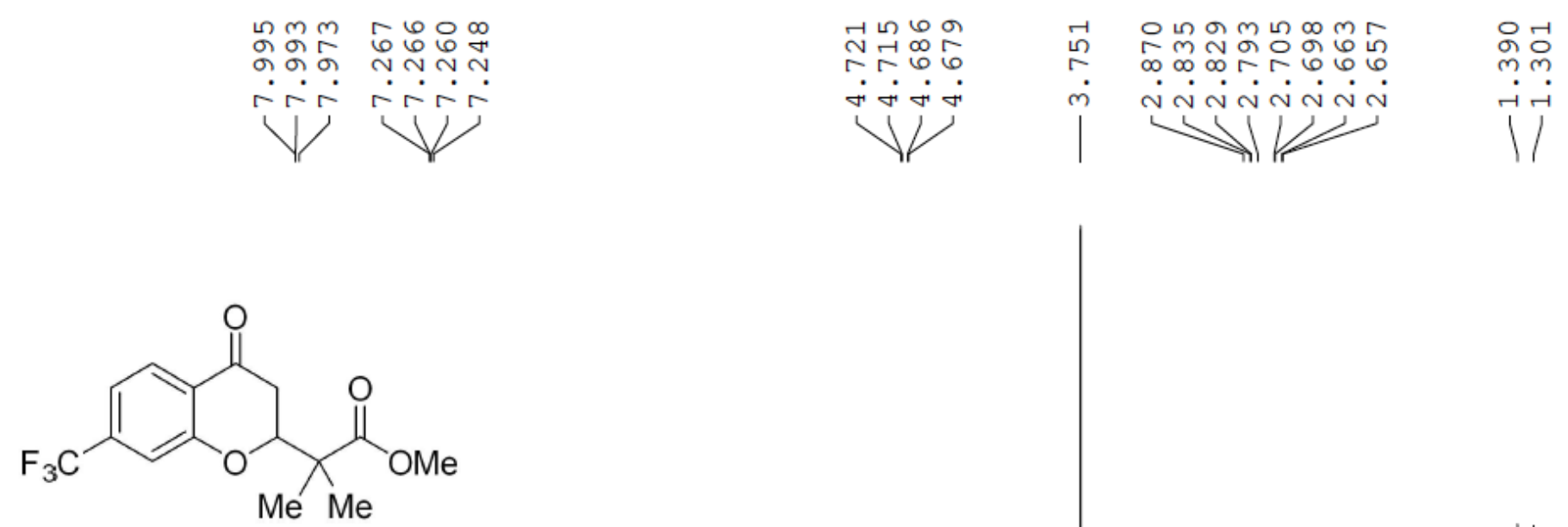

$4 h$

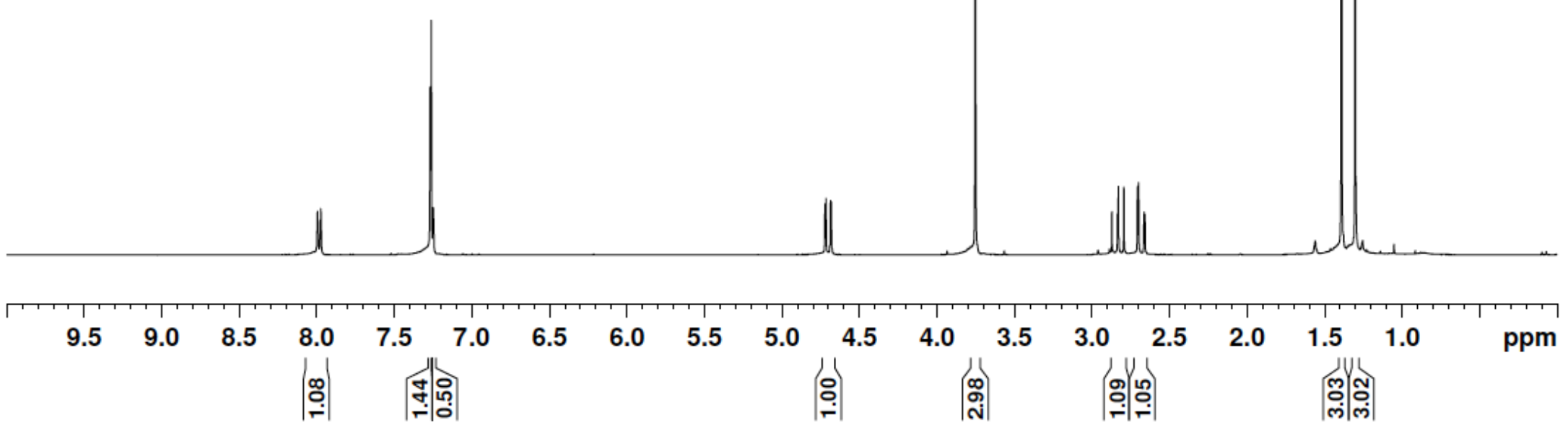




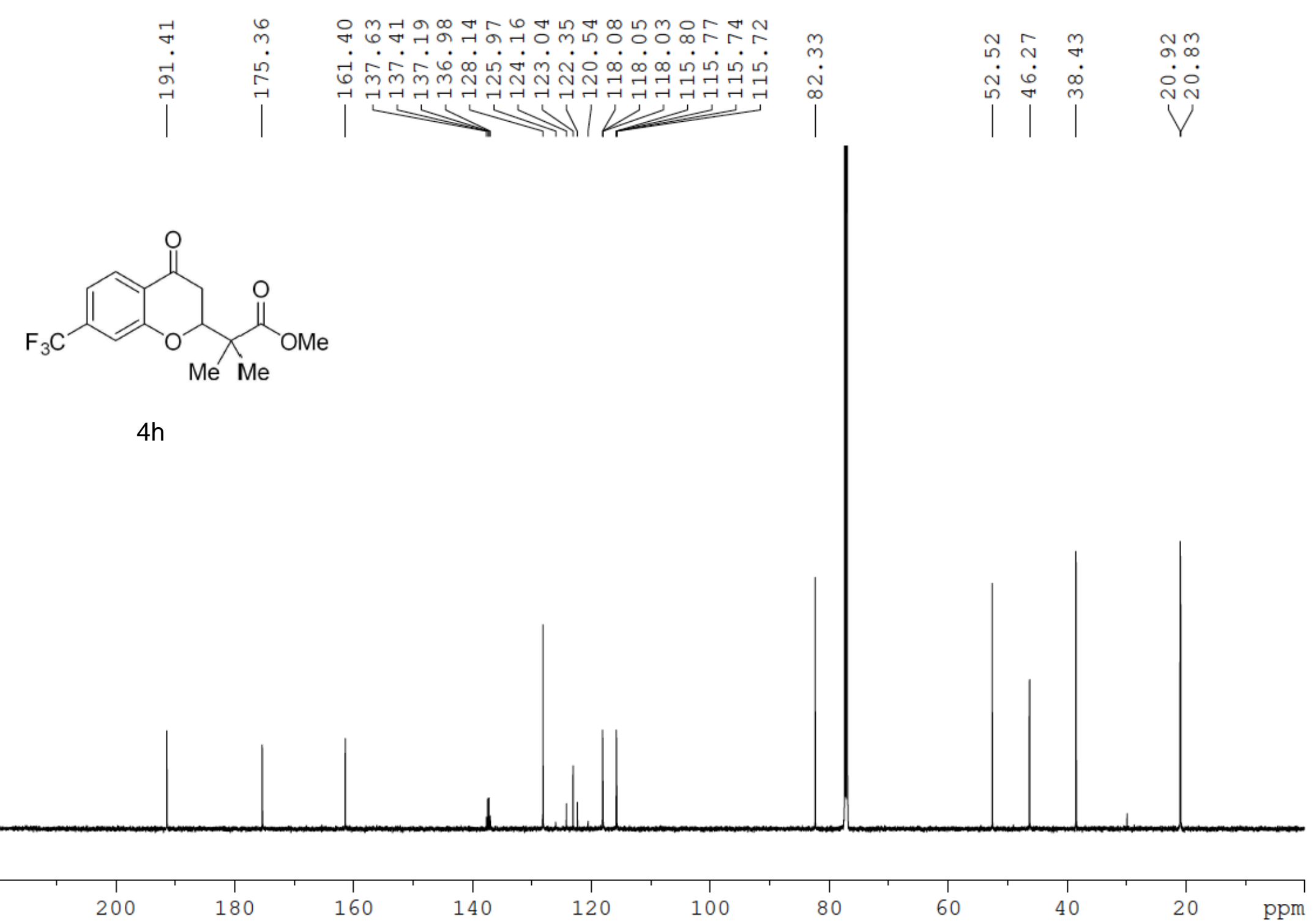



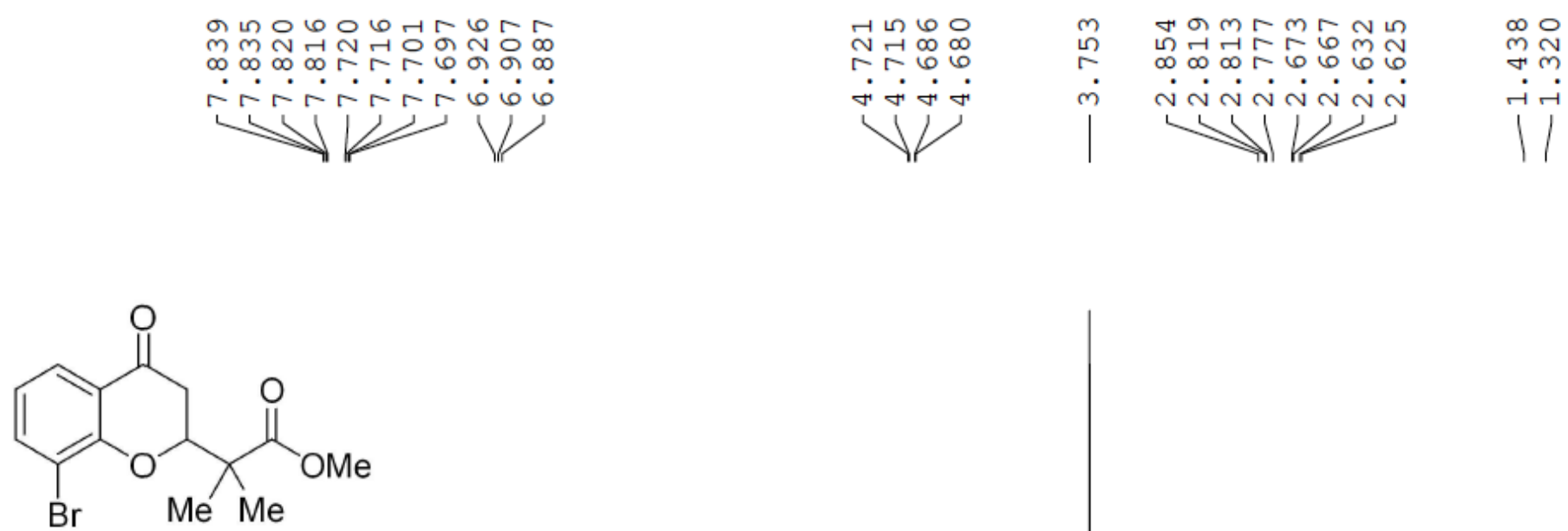

$4 i$

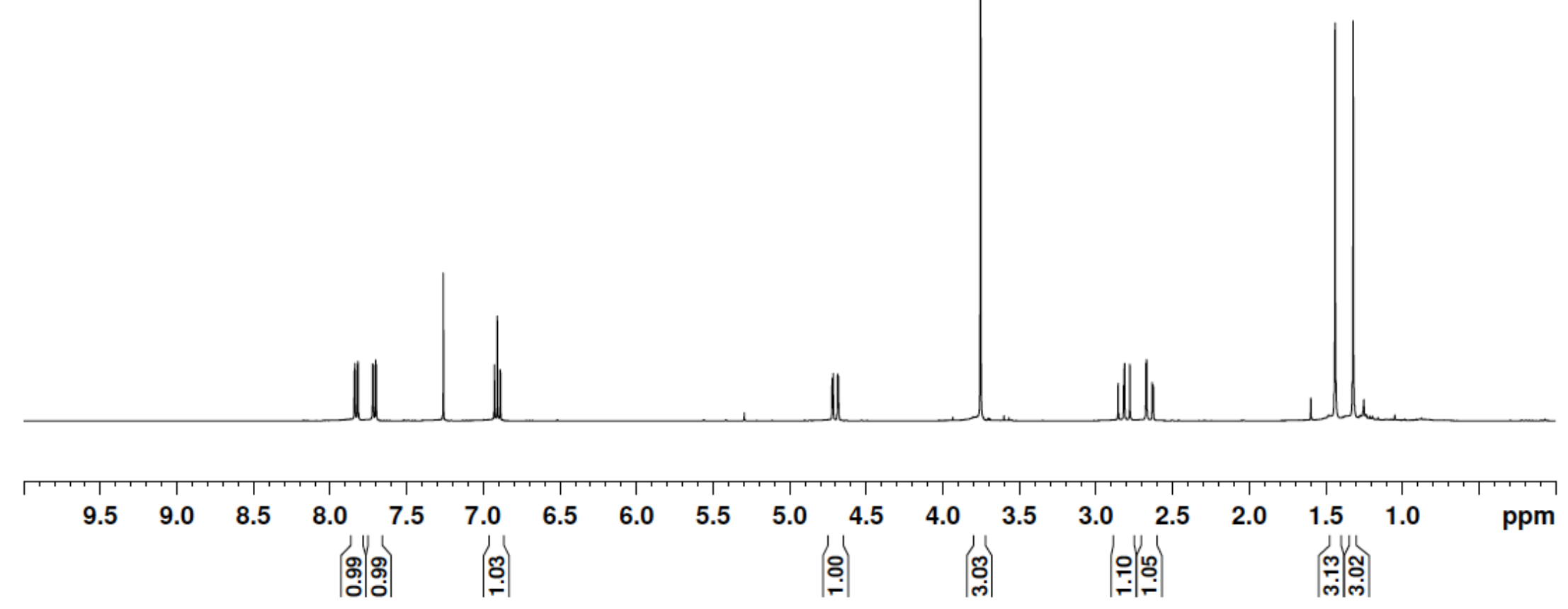




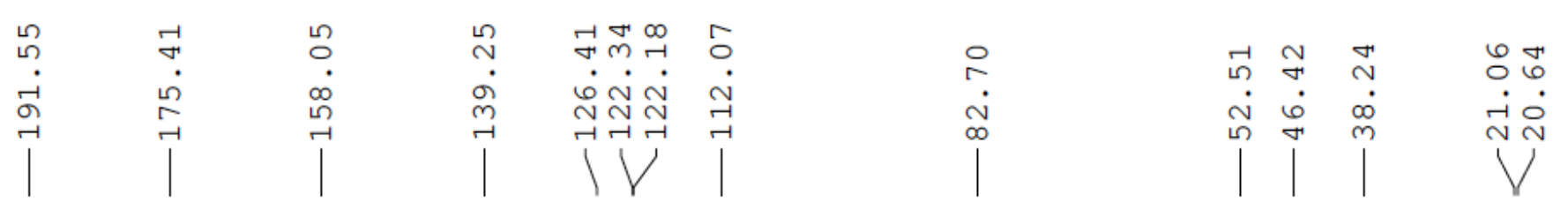

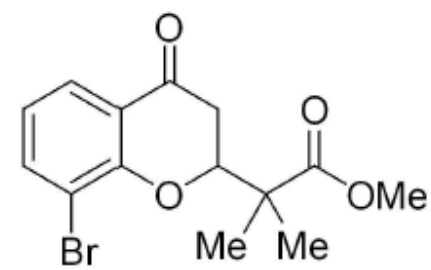

$4 i$

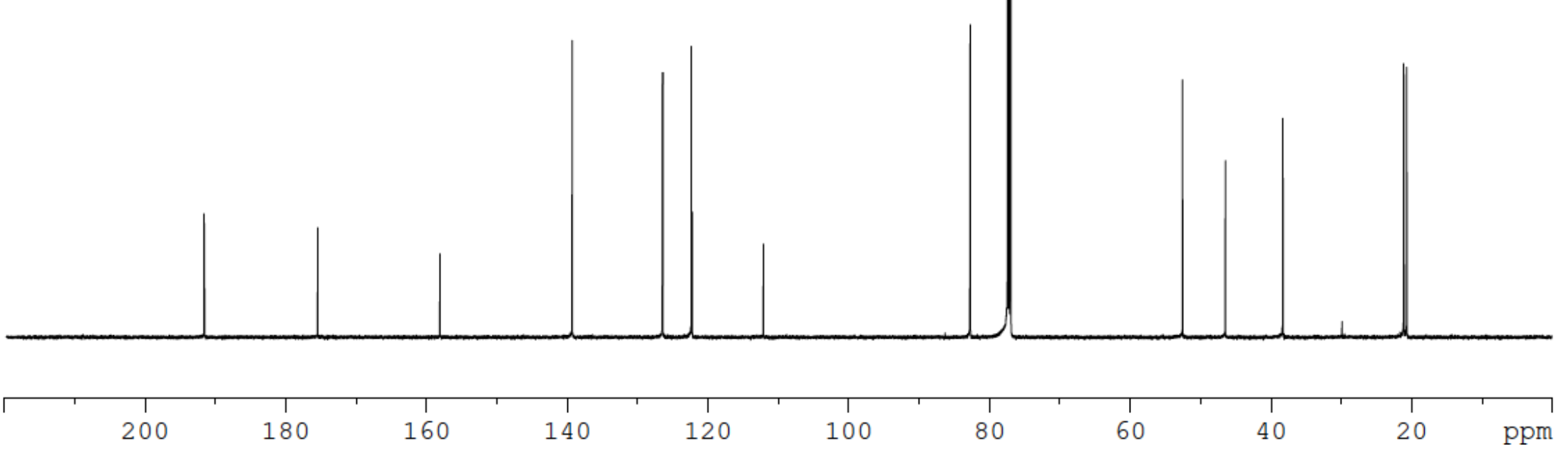




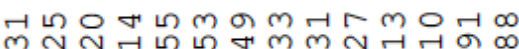

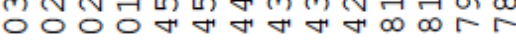

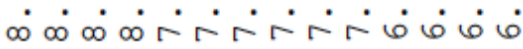

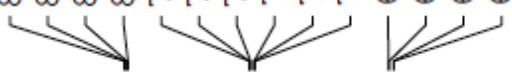

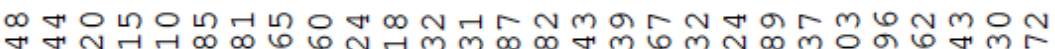

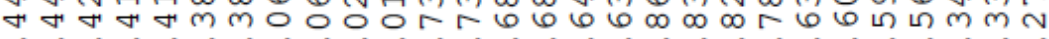

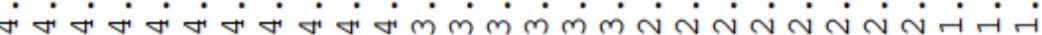<smiles>COC(=O)C(C)(C)C1C/C(=N\[S@](=O)C(C)(C)C)c2cc(Br)ccc2O1</smiles>

11

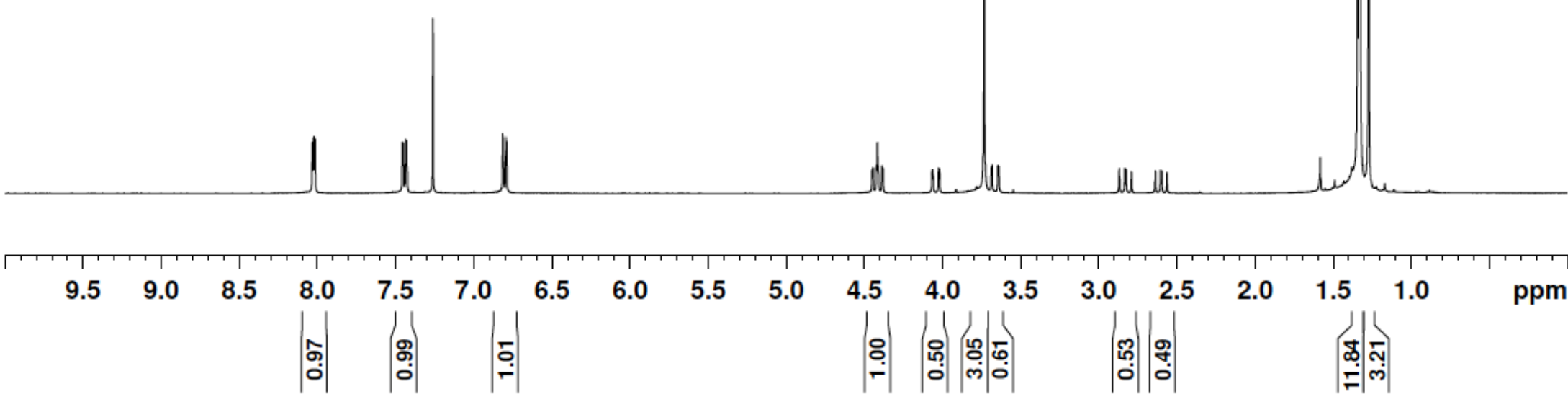



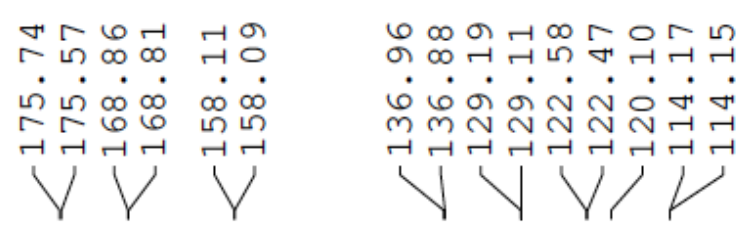

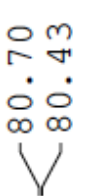
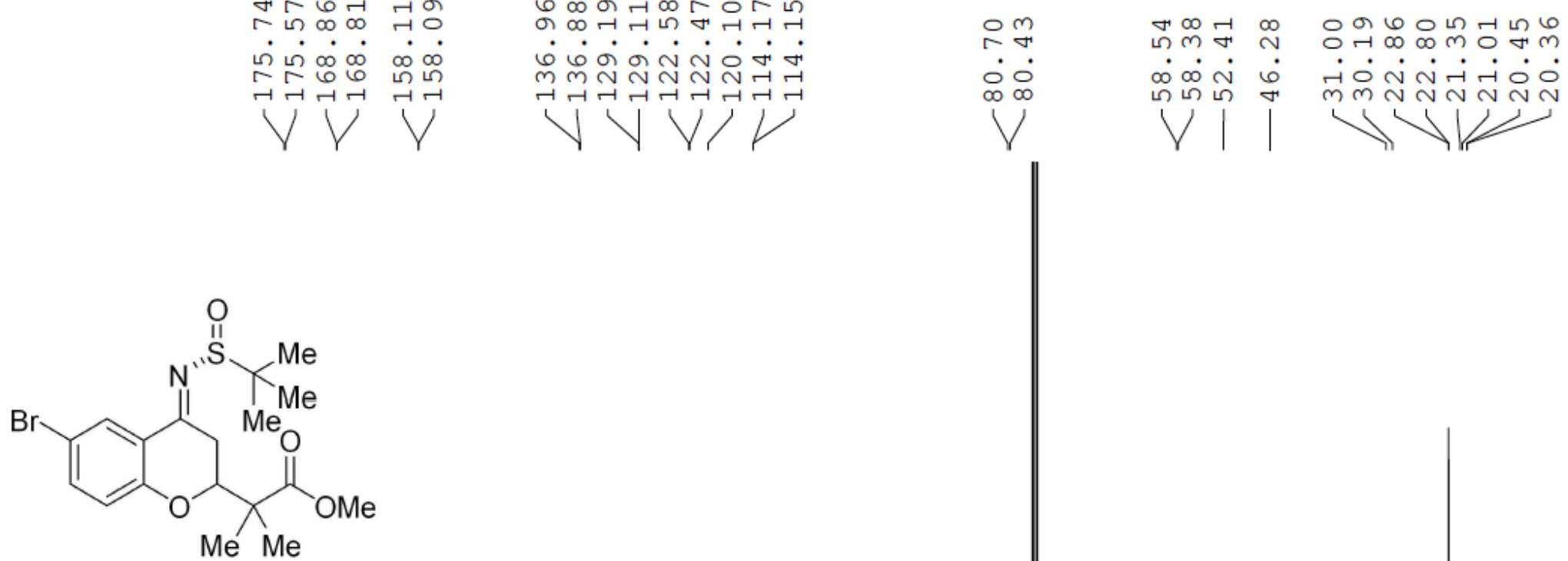

11

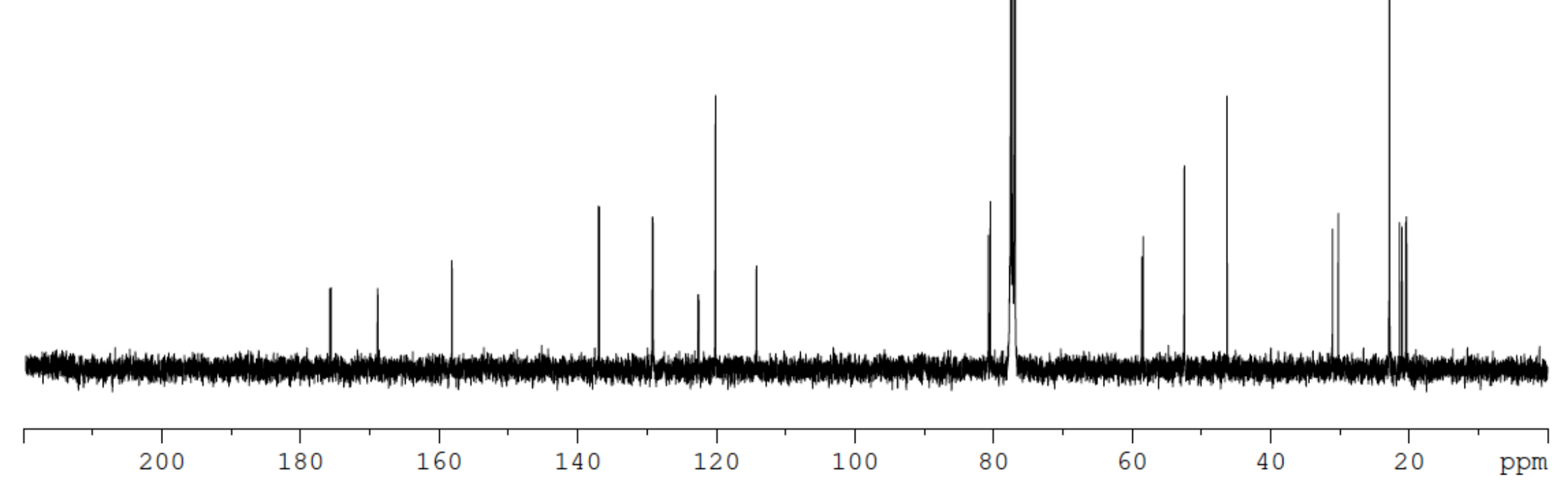




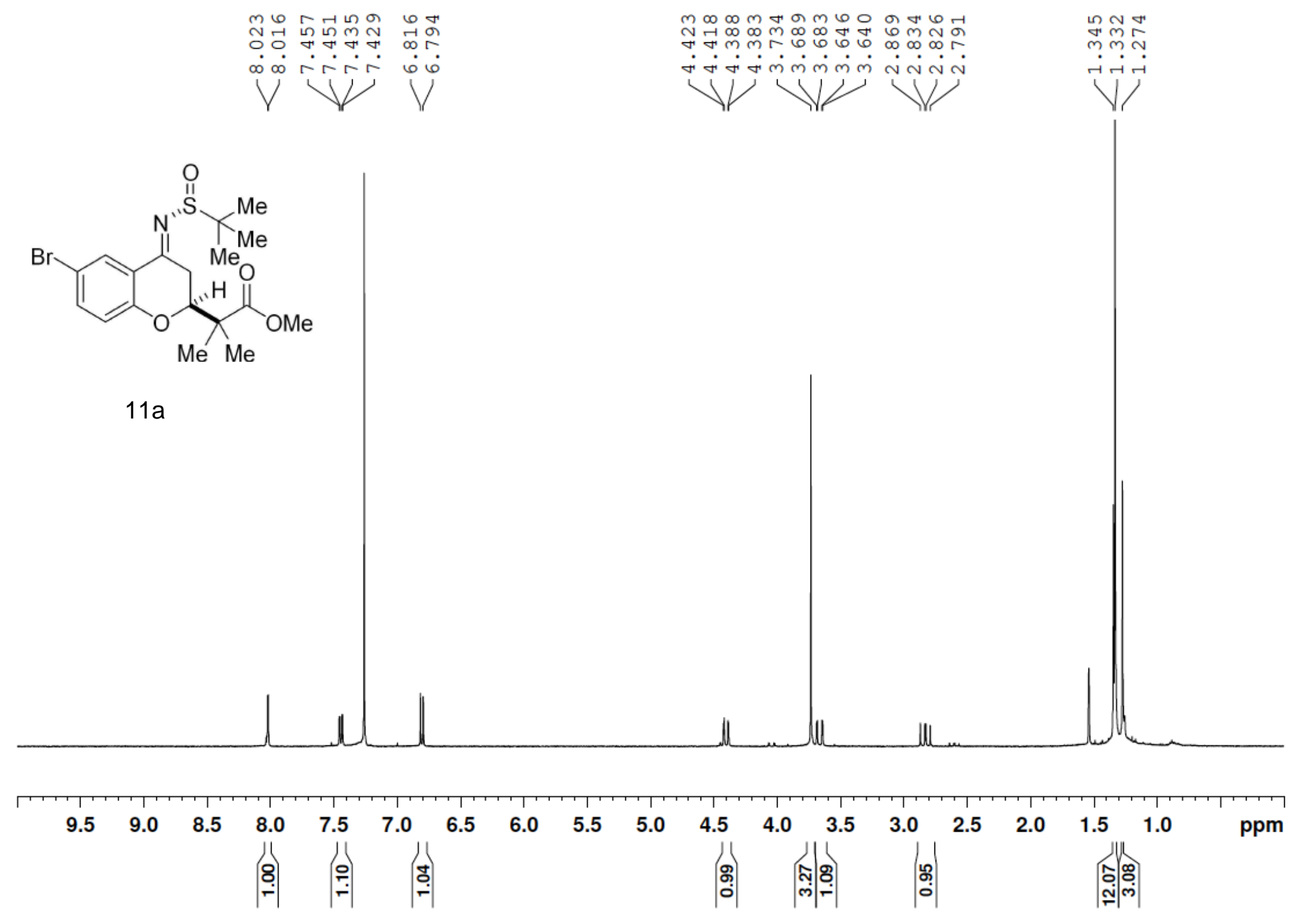




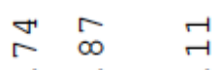

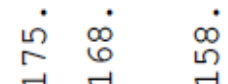

$$
\begin{aligned}
& \text { i }
\end{aligned}
$$

$$
\begin{aligned}
& \infty \text { 의 }
\end{aligned}
$$

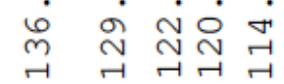

$$
\begin{aligned}
& \text { † }
\end{aligned}
$$

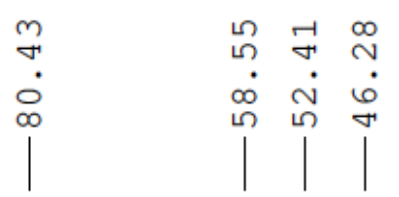

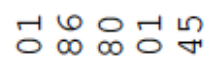

mNNำ

$1 / 1$

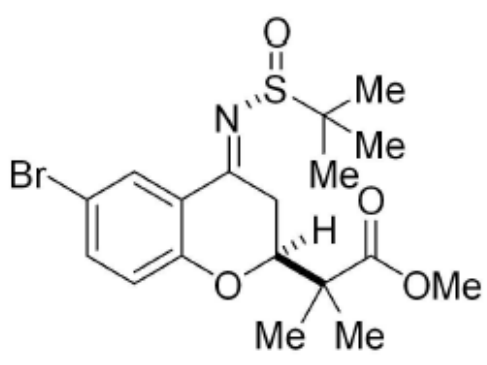

$11 \mathrm{a}$

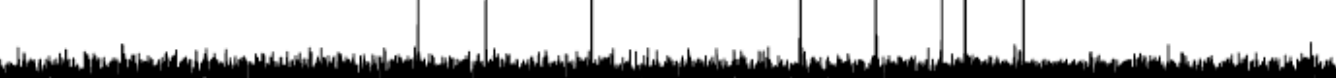

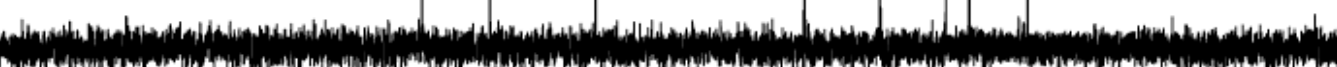
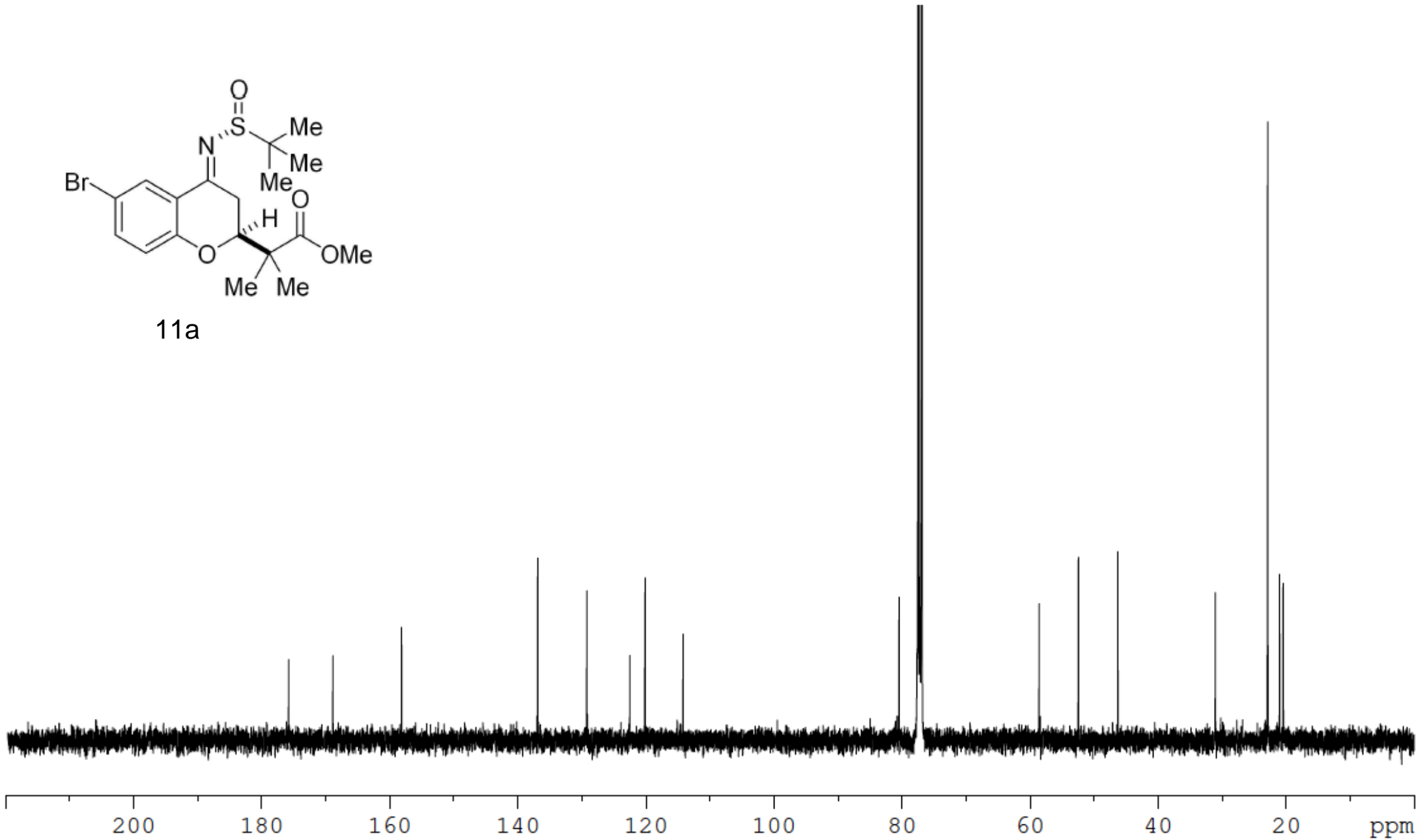